\title{
WestVirginiaUniversity
}

THE RESEARCH REPOSITORY @ WVU

Graduate Theses, Dissertations, and Problem Reports

2015

\section{Lower Greenmont Revitalization Featuring Deckers Creek}

Anna Marie Withrow

Follow this and additional works at: https://researchrepository.wvu.edu/etd

\section{Recommended Citation}

Withrow, Anna Marie, "Lower Greenmont Revitalization Featuring Deckers Creek" (2015). Graduate Theses, Dissertations, and Problem Reports. 7277.

https://researchrepository.wvu.edu/etd/7277

This Thesis is protected by copyright and/or related rights. It has been brought to you by the The Research Repository @ WVU with permission from the rights-holder(s). You are free to use this Thesis in any way that is permitted by the copyright and related rights legislation that applies to your use. For other uses you must obtain permission from the rights-holder(s) directly, unless additional rights are indicated by a Creative Commons license in the record and/ or on the work itself. This Thesis has been accepted for inclusion in WVU Graduate Theses, Dissertations, and Problem Reports collection by an authorized administrator of The Research Repository @ WVU. For more information, please contact researchrepository@mail.wvu.edu. 


\title{
Lower Greenmont Revitalization Featuring Deckers Creek
}

\section{Anna Marie Withrow}

Thesis submitted to the Davis College of Agriculture, Natural Resources and Design at West Virginia University in partial fulfillment of the requirements for the degree of

\author{
Master \\ of Landscape Architecture \\ Charles Yuill, M.L.A.(Chair) \\ Peter Butler, M.L.A. \\ Landscape Architecture Department \\ Patrick Kirby, M.A. (Collaborator) \\ Northern WV Brownfields Assistance Center \\ Steven Selin, $\mathrm{PhD}$ \\ Human Dimensions of Natural Resource Management \\ Morgantown, West Virginia \\ 2015
}

Keywords: Neighborhood Revitalization, Brownfield Redevelopment, Adaptive Reuse, Recreational Design, Community Planning

Copyright 2015 Anna Marie Withrow 


\section{ABSTRACT \\ Lower Greenmont Revitalization Featuring Deckers Creek}

Anna Marie Withrow

The Deckers Creek riparian corridor is a significant asset around which Morgantown, WV was developed. Historically, the corridor provided an important transportation route from the city to, connecting the area's industrial properties. The impacts of industrial development on the creek have caused it to be classified by the United States Environmental Protection Agency (EPA) as an impaired waterway. Restorative redeveloped along the riparian corridor and throughout the watershed will restore the value of this important natural resource and allow it to contribute to an improved improved local economy and quality of life. This project applies downstream focused redevelopment design strategies for neighborhood revitalization in a residential neighborhood in Morgantown.

This neighborhood revitalization plan will restore a new sense of neighborhood identity and pride in the Lower Greenmont Neighborhood. Pedestrian, stormwater, and site use improvements will be identified to enhance the neighborhood appearance, support the local economy, provide biophilia and recreation, and improve the outputs being sent downstream. The downstream design focus will restore a positive community perception of the adjacent creek and promote downstream thinking by appreciating the visual and recreational benefits that the waterway provides.

The plan is designed to be a neighborhood redevelopment guide that parallels the City of Morgantown's Comprehensive Plan, The Deckers Creek Watershed Based Plan, and the interests of the Greenmont Neighborhood Association. Adoption and prioritization of the suggested redevelopment projects by local champions and stakeholder groups may allow the document to serve as a guide for neighborhood redevelopment. The continued engagement of the local stakeholders that have participated in the project will allow local champions to push neighborhood revitalization projects forward. 


\section{Table of Contents}

Introduction ......................................................................... 7

Chapter 1 - Area Context...................................................

Walkability

Theoretical Framework:

Applied Framework:

Event Preparation

Event Reflections

Project Area: Lower Greenmont

Neighborhood History

Demographics

The Deckers Creek Corridor

Neighborhood Issues

Chapter 2 Project Mission............................................. 30

Vision

Project Goals and Objectives

Chapter 3 - Literature Review.

Chapter 4 - Participatory Design ............................. 34

Approach

Project Map

Chapter 5 - Inspiration

Seneca Center

Durango, Colorado Whitewater Park

Evergreen Brick Works

Chapter 6 Neighborhood Design

Master Plan

Signage

Pedestrian Improvements

Recreational Enhancements

Sedum

Stormwater Masterplan

Lower Greenmont Revitalization Stormwater Notes

Waterfront Redevelopment Area

Deckers Avenue Power Station

Deckers Avenue Power Station

Ervins Parking Area

Western Gateway

Eastern Gateway

Next Steps

References

Acknowledgements 


\section{Table of Figures}

Figures

Figure - I.1

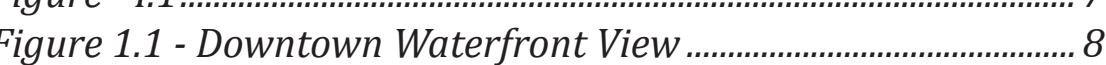

Figure 1.2 - Beaumont Glass...

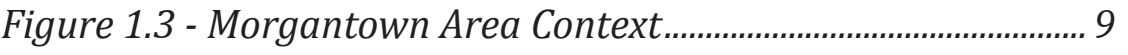

Figure 1.4 - Commercial Development ……………………..............10

Figure 1.5- Brockway Stormwater ........................................................11

Figure 1.6 - Waterfront Trail .................................................................11

Figure 1.7 - Sacred Structure of Lower Greenmont. ....................12

Figure 1.8 - Historic Development...........................................................14

Figure 1.9 - Neighborhood Character Collage

15

Figure 1.11 - The Wilson Works Building from Deckers Avenue15

Figure 1.12 .........................................................................................

Figure 1.15 - Lower Greenmont Deckers Creek Analysis ...............18

Figure 1.16 - Lower Greenmont Deckers Creek Analysis...............21

Figure 1.17

Figure 118 -Industrial Waterfront

Figure 1.20

Figure 1.19...........................................................................................2

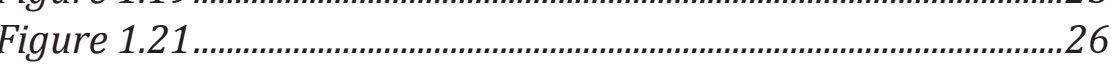

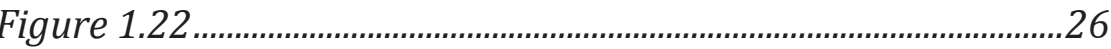

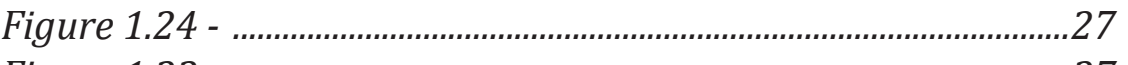

Figure 1.23..................................................................................................2

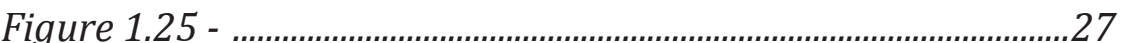

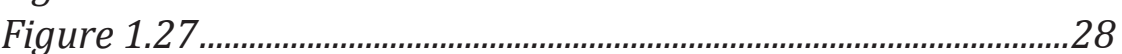

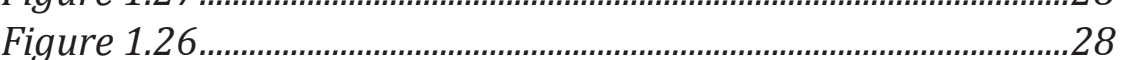

Figure 1.28...............................................................................................29

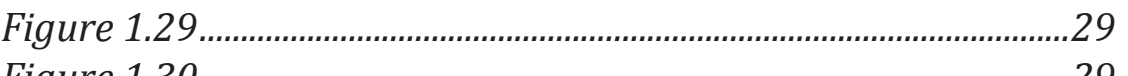

Figure 1.30........................................................29

.

Figure 3.2 - Home on Pennsylvania Ave Floodin

Figure 4.1 - Community Engagement Graphic...................................34

Figure 4.2 -Invitee Graphic ...........................................................................35

Figure 4.3 - Project Map.........................................................................36

Community Event, Data Collection, and Site Analysis..................37

Figure 4.5 - Recreation and Quality of Life Focus Group ................41

Figure 4.6- History and Sustainability Group Presentation...........41

Figure 4.6- History and Sustainability Group Presentation ..........41

Figure 4.8.
Figure 4.10

.. .43

Figure 4.11

Figure 4.12 - Sacred Structure Focus Group Map..................................44

Figure 4.13 - Recreation and Quality of Life Focus Group Map..44

Figure 4.14 - History and Sustainability Focus Group Map..........45

Figure 4.15 - Identity and Branding Focus Group Map..................45

Figure 4.16 - Sacred Structure Discussion Overview.......................46

Figure 4.17 - History and Sustainability Discussion Overview ...48

Figure 4.18 - Identitiy and Branding Discussion Overview..........50

Figure 4.19 - Rec and Quality of Life Discussion Overview...........52

Figure 5.1 - Seneca Center

Figure 5.2 - Seneca Center Trail Access

. .54

Access............................................54

Figure 5.3 - City of Durango Primary Improvement Area Plan..55

Figure 5.4 - Animas River Sight and Access Improvements..........55

Figure 5.5 - Animas River In-Stream Enhancements .......................55

Figure 5.6 - Evergreen Brickworks Garden .......................................56

Figure 5.7- Don Watershed Model....................................................56

Figure 5.8 - Evergreen Brick Works Welcome Center ......................57

Figure 5.9 - Evergreen Brick Works Koerner Gardens.....................57

Figure 5.9 - Evergreen Brick Works Ice Skating Rink ....................57

Figure 6.1 - Lower Greenmont Revitalization Master Plan ..........58

Figure 6.3 - Arch Street Sign Design......................................................60

Figure 6.2.

.. .60

Figure 6.5-Sedum ....................................................................................61

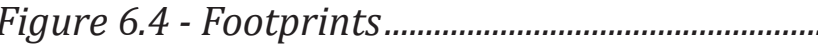

Figure 6.6

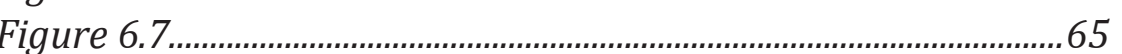

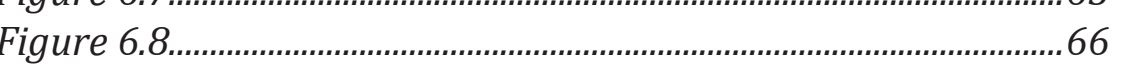

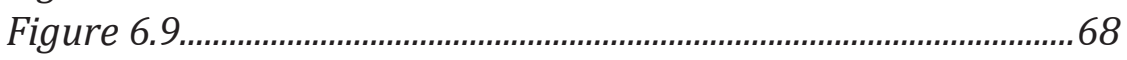

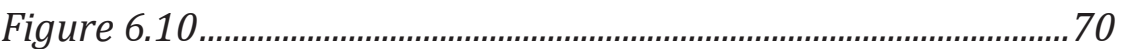




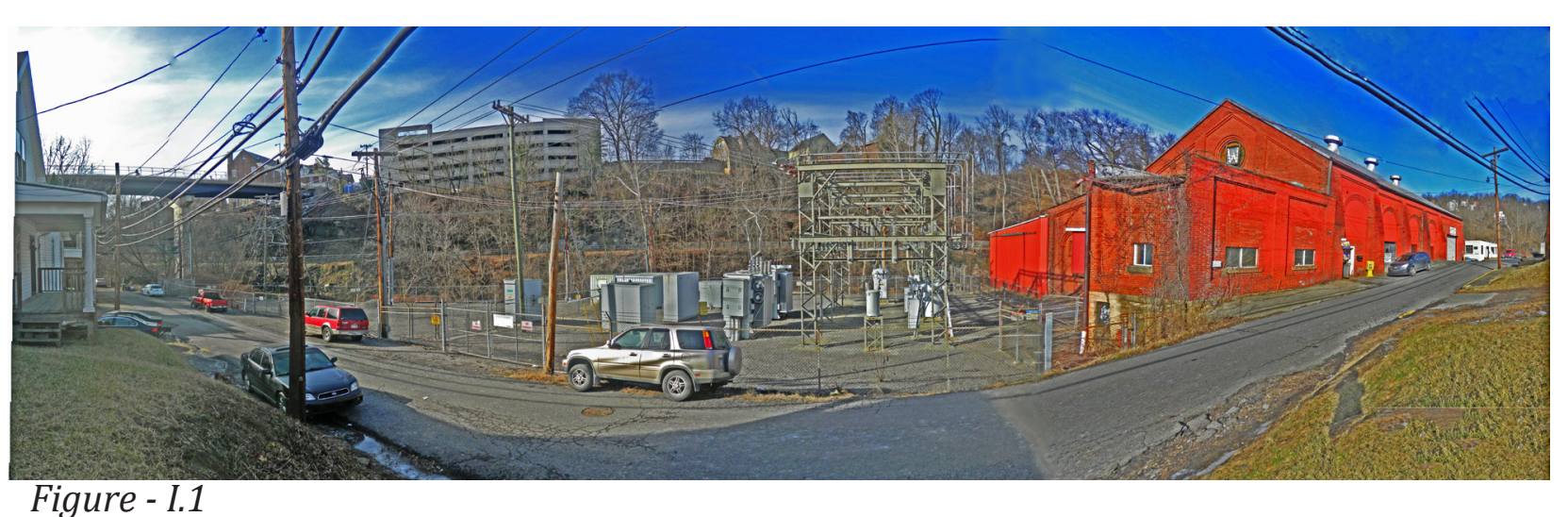

\section{Introduction}

This document summarizes a process of neighborhood analysis, community engagement, and design that was conducted during the spring of 2015 in the Lower Greenmont Neighborhood in Morgantown, WV. The neighborhood analysis highlights neighborhood assets, issues, and revitalization opportunities. Recognizing the underappreciated neighborhood waterway as a valuable neighborhood asset worth protecting the revitalization plan focuses on restoring the varal quality of Lower which the neighborhood may benefit.

The participatory design process outlines the process of connecting with various local stakeholder groups and individuals, the planning and execution of a structured community engagement event and the synthesis of meeting results to create a collaborative community design. The resulting neighborhood revitalization plan addresses key neighborhood issues and identifies practical design solutions for community enhancement. The reinvisioned Deckers Creek waterfront will serve as a central feature, vibrant with recreational, commercial, and ecological activity. The design will promote waterway health by identifying the highest and best use of underutilized industrial infrastructure, restoring the natural waterway ecology, reducing stormwater runoff, and promoting walkability. The improvement of the neighborhoods pedestrian environment will promote local businesses, lessening the need for vehicular transportation. The focus of the project is to provide the community with accurate information and representations of the issues, with achievable short and long term goals for neighborhood revitalization. 


\section{Chapter 1 - Area Context}

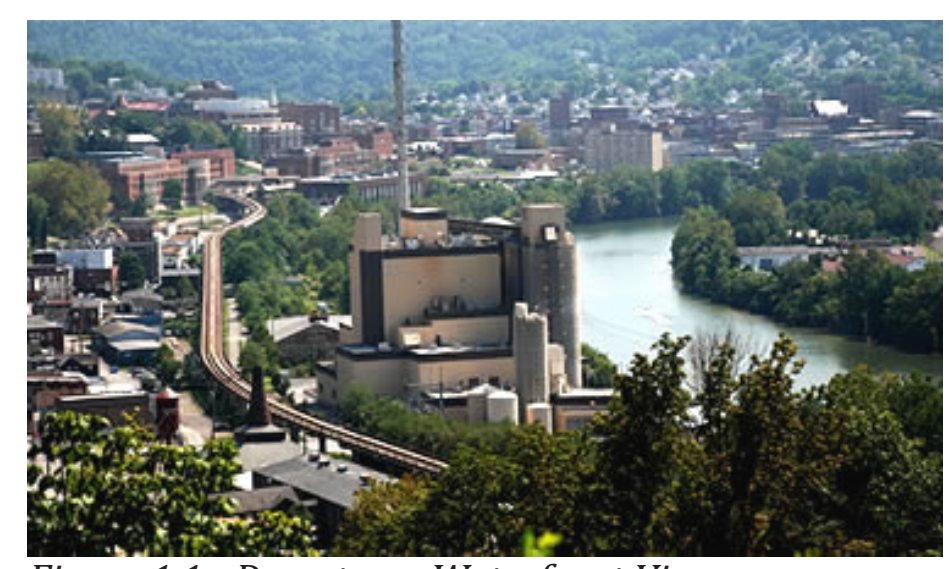

The Deckers Creek riparian corridor s a significant asset around which Morgantown Historically, the corridor provided an Historically, the corridor provided an ity to conn city to, connecting the area's industria properties. The impacts of industrial 作 it to be classified by the United States Environmental Protection Agency (EPA) as an impaired waterway. Restorative redeveloped along the riparian corridor and throughout the watershed will

restore the value of this important
natural resource and allow it to contribute to an improved improved local economy and quality of life. This project applies downstream focused redevelopment design strategies for neighborhood revitalization in a residential neighborhood in Morgantown.

This neighborhood revitalization plan will restore a new sense of neighborhood identity and pride in the Lower Greenmont Neighborhood. Pedestrian, stormwater, and site use improvements will be identified to enhance the neighborhood appearance, support the local economy, provide biophilia and recreation, and improve the outputs being sent downstream. The downstream design focus will restore a positive community perception of the adjacent creek and promote downstream thinking
by appreciating the visual and recreational benefits that the waterway provides.

The plan is designed to be a neighborhood redevelopment guide that parallels the City of Morgantown's Comprehensive Plan, The Deckers Creek Watershed Based Plan, and the interests of the Greenmont Neighborhood Association. Adoption and prioritization of the suggested redevelopment projects by local champions and stakeholder groups may allow the document to serve as a guide for neighborhood redevelopment. The continued engagement of the local staked that have participated in theholders will allow local champions to push will allow local champions to push forward.

The core downtown area of Morgantown is bound on three sides by the Monongahela River and

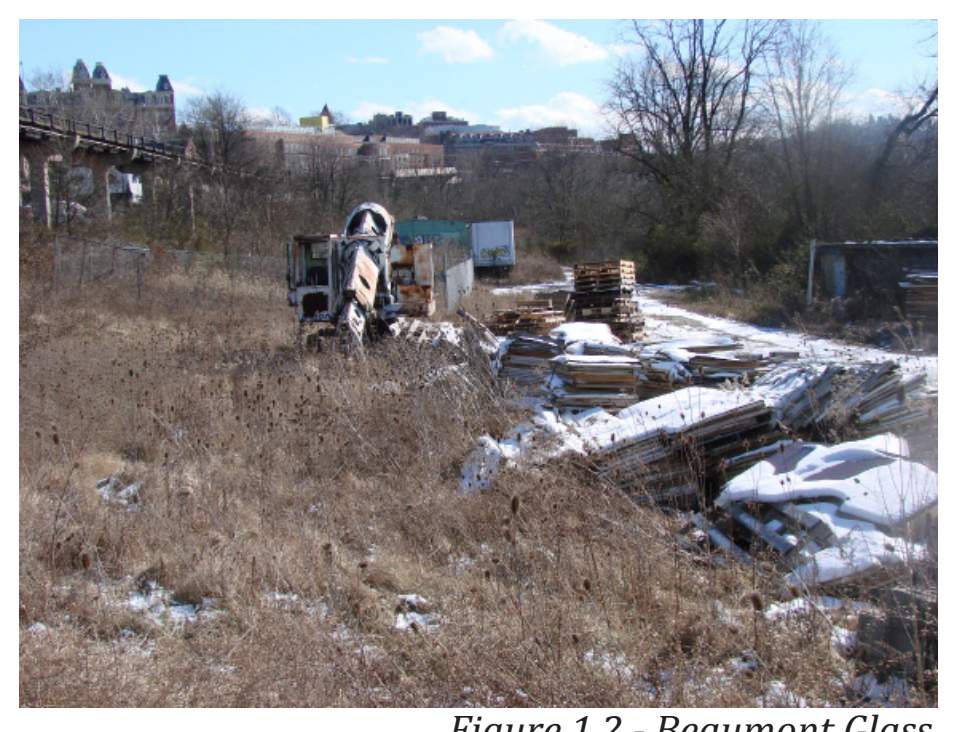

Figure 1.2 - Beaumont Glass Remnants of the industrial development at the former Beaumont Glass Factory

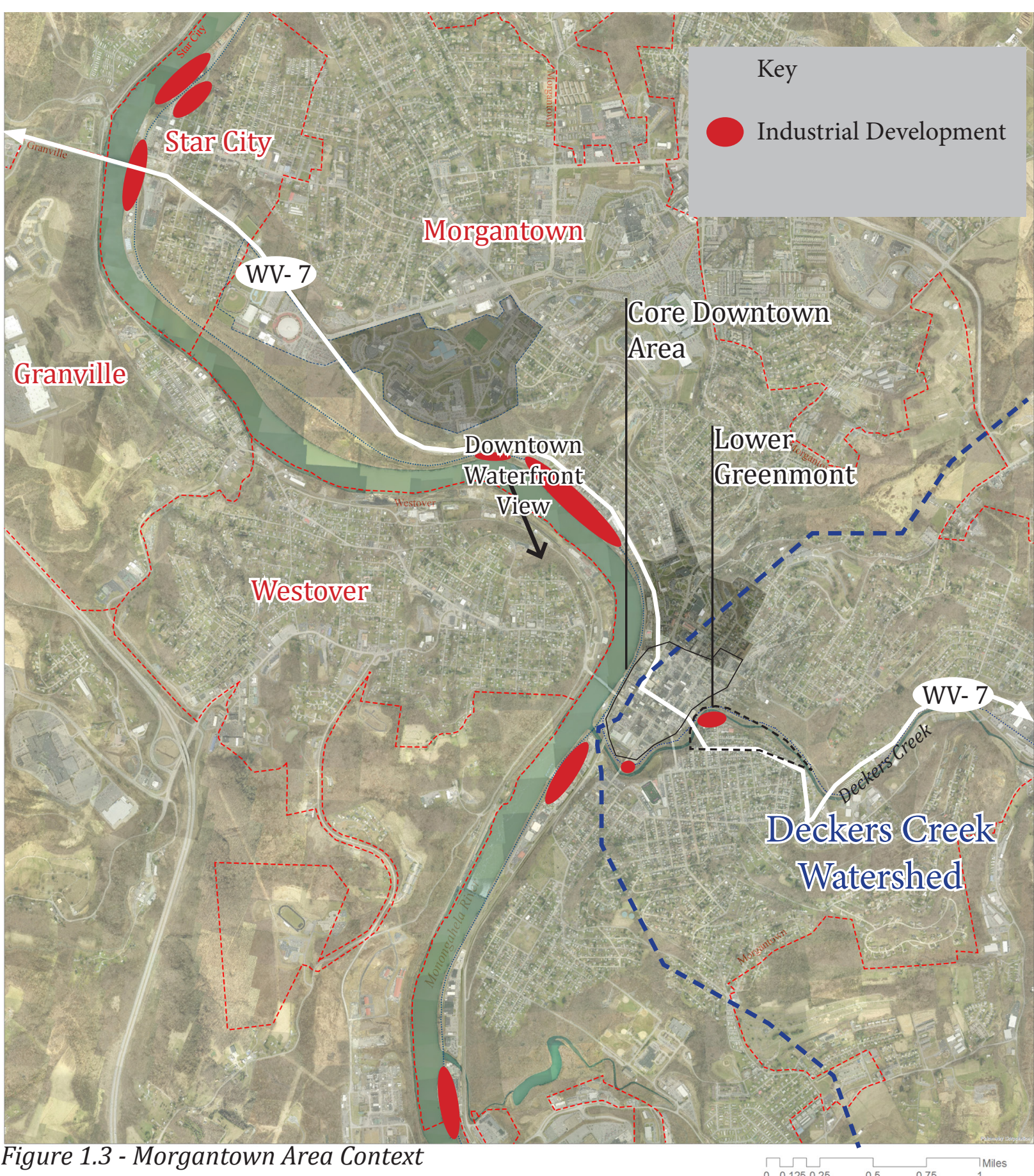

Deckers Creek waterfronts, making the waterways key community features. Throughout the late 1800 's and most of the 1900's, the banks of both waterways were lined with railroad infrastructure that serviced a limestone quarry, coal mines, a flat boat manufacturing facility, and numerous glass factories. This heavy industrial waterfront development has served as a barrier, limiting the ability of the local wildlife, population, and economy to utilize the valuable community asset. The impacts of development and activity upstream in the watersheds has degraded water body health and is contributing to negative perceptions of the waterways. The decline of local extraction and production industries over time has resulted in underutilized waterfront industrial properties. 
These properties provide opportunities to preserve the area's industrial heritage feature the waterways as a recreational and visual asset restore waterway ecology and offer more pedestria accessible commercial acilities. Neighercial facilltes. Neighborhood ches a takes advantage of these opportunities may transform the waterfront into an ecologically and socially diverse community center. The mitigation of stormwater influx and pollutants from areas throughout the watersheds will improve site ecology and aesthetics, contributing to neighborhood revitalization.

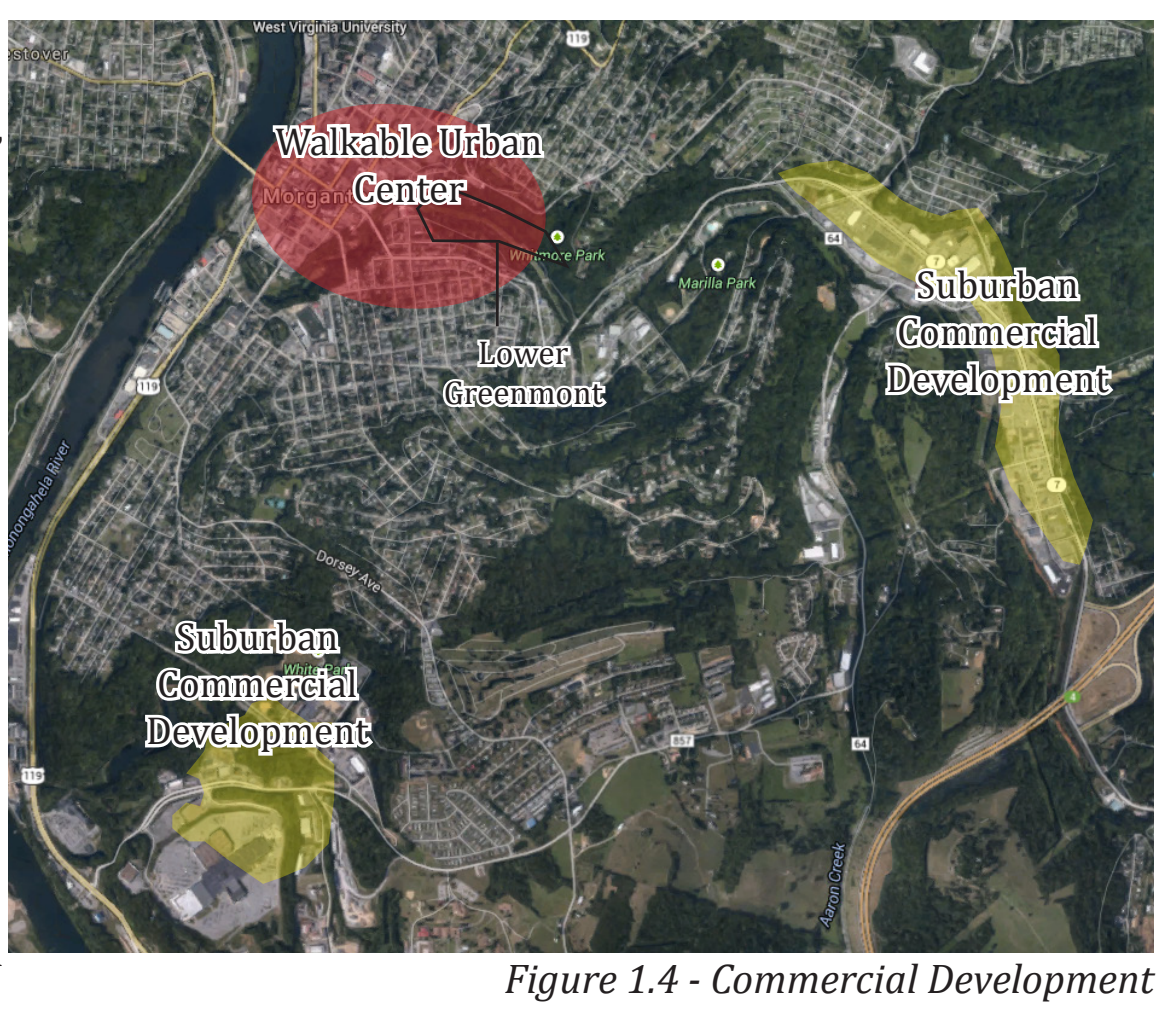

Many communities throughout Appalachia were developed along the banks of rivers and streams in order to take advantage of the benefits that they provide. Many waterfront properties were developed and used for water access, hydroelectric power, and transportation. This has resulted in (n) to the stean banks being lined with large, industral waterfont buildings and equipment. Prior to the existence of the Clean Water Act in 1972, it was commonplace for populations to utilize waterways for the removal of chemical and debris pollution. There have since been immeasurable instances of accidental and illegal use of waterways for waste removal. This type of utilitarian waterfront development and activity has created a physical barrier between populations and nearby water bodies, and is likely contributing to degraded public perception of riparian areas. A 2010-2011 Brownfields Survey, conducted by Friends of Deckers Creek revealed that the community views Deckers Creek as scenic, yet polluted by past and present industrial practices as well as raw sewage.

The development of residential and commercial structures, parking areas, and roadways has created large areas of impervious surfaces that contribute to further stream degradation by causing large influxes of untreated runoff during rain events and preventing groundwater recharge from happening between rain events. This causes problems downstream such as erosion, flooding, and water contamination. Water is contaminated as runoff rinses petroleum, chemicals, pet waste, and debris from surfaces throughout the watershed. Combined sewer - overflow systems contaminate waterways with fecal chloroform during large rain events.

Convenient commercial centers that sprawl from the city have led to a need for more vehicular infrastructure and have created cultural norms which have negative impacts on the local economy, from the walkable urban center into suburban areas. This has had a negative impact on the local

economy because suburban commercial centers typically generate revenue for large businesses that transfer profits out of the area. Vacant commercial spaces along Brockway Ave may also be attributed to suburban commercial developments. Over time, this has lead to a limited selection of local downtown businesses, making access to suburban commercial areas a necessity for urban residents. Although residents within the walkable urban center have pedestrian access to much of their needed amenities, individual vehicle ownership seems to be the only reasonable means for residents to access these commercial centers. Individual vehicle ownership in the urban environment creates the unnecessary financial burden of vehicle ownership and maintenance for residents. It also hin for residents. within the city has contributed to pollution hot spots along highly trafficked vehicular within the city has contributed to pollution hot spots along highly trafficked vehicular

The conversion of river and creek-side railways into recreational trails has allowed many of these waterfronts to be transformed into recreational zones. Vacant, abandoned, and underutilized trailside industrial properties litter the urban waterfront. Industrial waste remaining on these properties is contributing various types of chemical and mineral pollution. Furthermore, these derelict spaces have become inviting places for unwanted and illegal activities, often resulting in debris pollution. This causes trail users to feel unsafe in and avoid these locations. Redevelopment efforts in recent years at the Seneca Center and the Downtown Wharf have repurposed industrial properties for mixed use. The redeveloped commercial centers offer trail-side accesses that face the river, improving the access and safety of the recreational corridor. Further redevelopment which

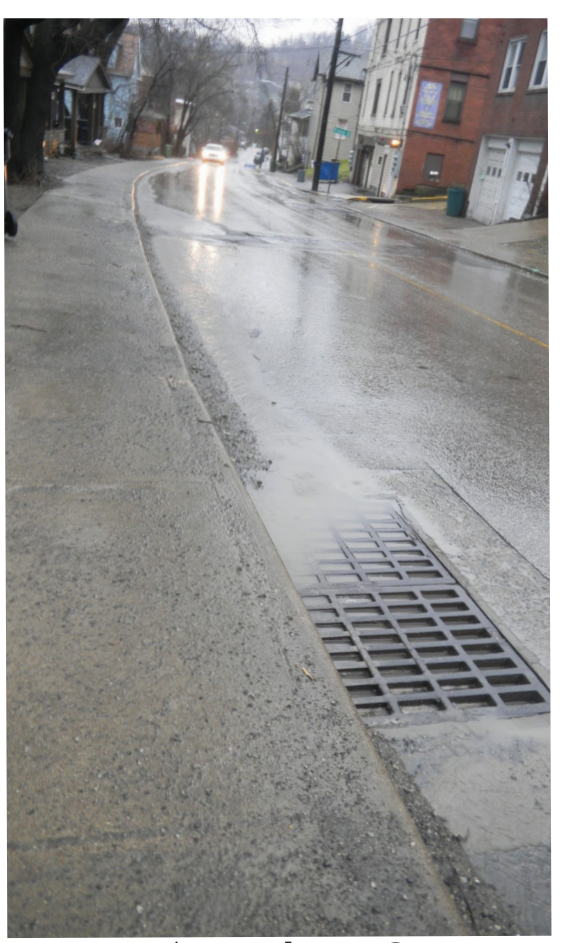

Figure 1.5- Brockway Stormwater This photo was taken on Brockway Avenue during a rain event. Storm drain B6 is shown to be full and overflowing into the next catchment area. focuses on the waterfront will continue to enhance and link more areas to the trail network.

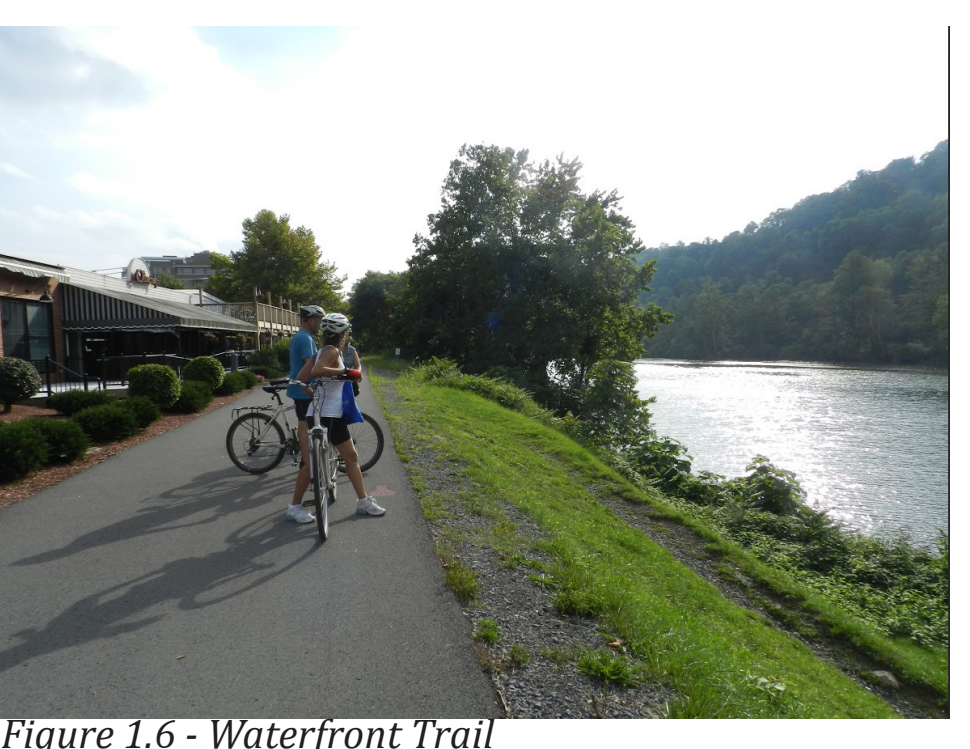

Redevelopment efforts in the Wharf District have repurposed the industrial waterfront for mixed commercial and recreational use. 
Project Area: Lower Greenmont

This neighborhood revitalization design project for the Lower Greenmont Neighborhood in Morgantown will focus on the improvement of downstream waterways through community enhancement proposals. The reinvisioned Deckers Creek waterfront will serve as a central feature, vibrant with recreational, commercial, and ecological activity. The design will promote

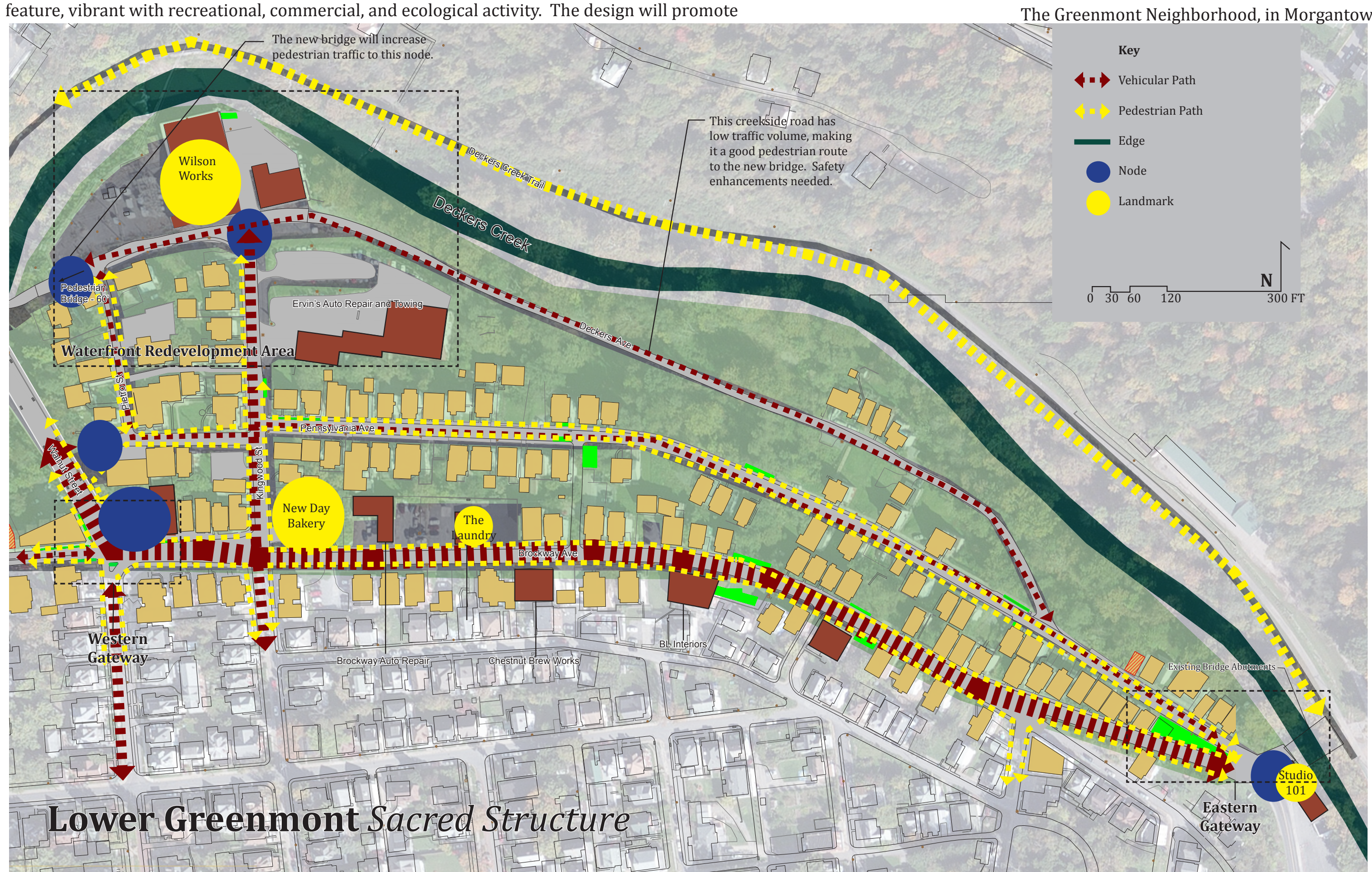

waterway health by identifying the highest and best use of underutilized industrial infrastructure, restoring the natural waterway ecology, reducing stormwater runoff, and promoting walkability. The improvement of the neighborhoods pedestrian environment will promote local businesses, essening the need for vehicular transportation.

nawn, WV can be found on WV State Route 7, between rea located in Morgantown's Second Ward is bound by Deckers Creek, Brockway Avenue and the be walk walkable neighboho is Thess is chers Creek from Downtown Morgantown. There is convenient vehicular and pedestrian Mccess across the creek from Brockway Avenue. Much of Greenmont is located on a flat Plateau, extending south from Brockway Avenue. The Lower Greenmont neighborhood, lies on a steep slope from Brockway Avenue down to the creek. The neighborhood slope and orientation make it highly visible for pedestrians crossing the Walnut Street Bridge to and from downtown. Neighborhood design will provide optimal walkability for neighborhood residents and guests.

The Lower Greenmont Neighborhood is an opportune location for neighborhood revitalization because of neighborhood liabilities and potential. Derelict and underutilized properties deter neighborhood aesthetics and safety. The adaptive reuse of these spaces which utilizes the visual and recreational benefits of the adjacent creek will transform the blighted waterfront into a trail will transform the blighted waterfont into a trail destination and neighborhood hub that supports human and ecological community development. This project identifies the new pedestrian bridge as a catalyst for neighborhood enhancement. The Kerns Crossing Pedestrian Bridge will provide outdoor recreation and commuting opportunities by linking the neighborhood to the rail-trail network. The architectural character and layout of the historic community will contribute to the neighborhoods attractiveness to trail users and potential residents. 


\section{Neighborhood History}

The Greenmont neighborhood was recognized in 2005 as a Registered Historic District by the National Registry of Historic Places. The land that comprises current-day Greenmont was part of a 600 acre farm that was purchased in 1772 by Michael Kerns. Much of the neighborhood remaine undeveloped until the late 1800's (Gioulis, 156). The neighborhood was developed throughout the early 1900's and served as a primarily ethnic and working-class neighborhood. During early development, many residents did not have the luxury of personal vehicles. Neighborhood location offered pedestrian access to Downtown, Sabraton, and Marilla, where many residents worked at glass factories, coal mines, and a tin plate mill (Gioulis, 160). "In the late 1920's and early 1930's, Greenmont had at least 11 grocery stores, meat markets, bakeries, and confectioneries", as well as several "auto repair shops, barber shops, restaurants, and pool halls", with several additional grocery stores located just outside the neighborhood border (Gioulis, 2)

Thoney Pietro, an Italian mason and local legend, resided in Greenmont. His company, Pietro Paving and Construction, constructed many of the roads in the neighborhood and throughout Morgantown (Stasick, 2006). There are severatremaining strunture area that were constructed neighborhood character.

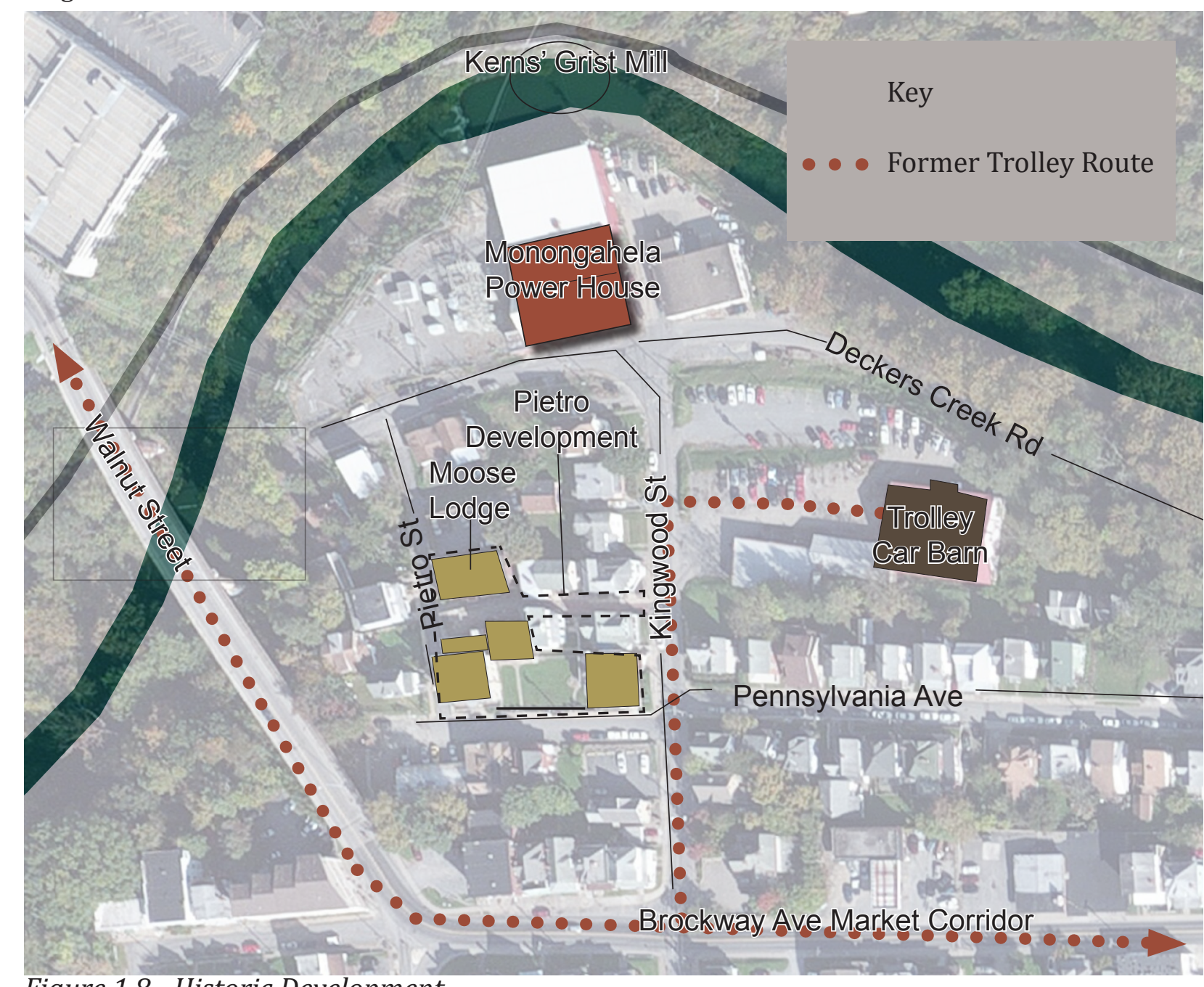

Figure 1.8 - Historic Development
The large, brick industrial building on the Deckers Creek waterfront that is known today as the Wilson Works facility, was built in the early 1900's and was a coal fired power plant known as the West Virginia Utilities Company Powerhouse. The low head dam behind the structure was a grist mill. By mid century, the Deckers Avenue Power Station infrastructure and white block building were constructed on either side of the powerhouse.

Another key neighborhood historic industry was the trolley. The present day Ervins towing property housed a trolley "car barn" through the early 20th century. The trolley connected to downtown via Deckers Creek Road and the bridge that is to be reconstructed.

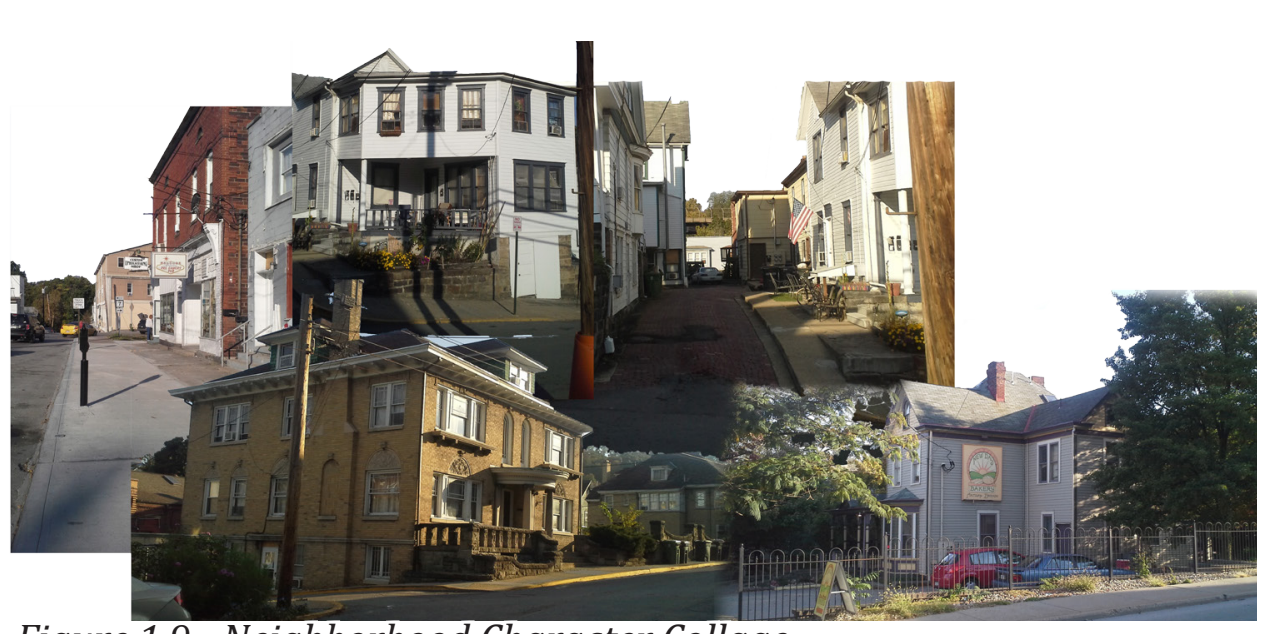

Figure 1.9 - Neighborhood Character Collage

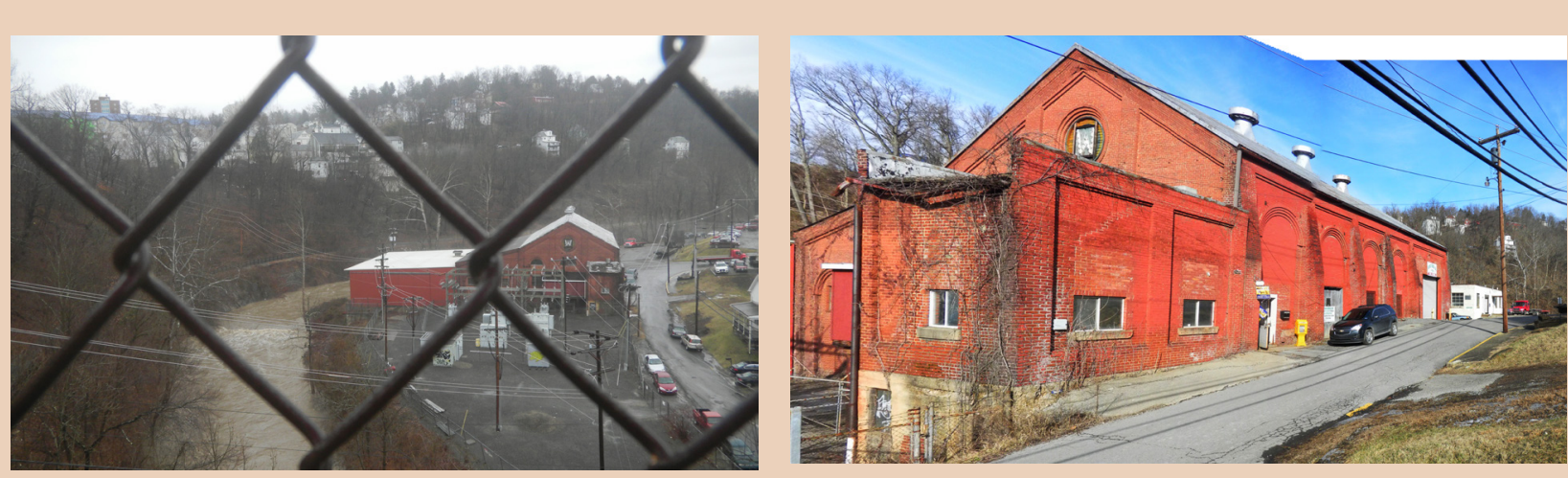

Figure 1.10 above demostrates the visibility Figure 1.11 - The Wilson Works Building of the industrial waterfront from the Walnut from Deckers Avenue Street Bridge. 


\section{Demographics}

Greenmont is comprised of a mix of owner-occupied and rental residential structures. Since the 1940's many of Greenmont's commercial facilities and larger homes have been subdivided and converted into rental residential units. Many of these units are currently occupied by students. A successful local bakery, a furniture upholstery facility, a salon, an interior design and product facility, along with the recently or soon to be opened pub and grill, brewery, and laundromat facilities along Brockway Avenue currently service the neighborhood.

The Greenmont Neighborhood Association(GNA) is an active group of neighbors that meet monthly, host annual events, and mobilize for community betterment.

In Lower Greenmont, the median household income is less than 30,000 per year and the median age is less than 28 (Census 2011).

\section{Walkability}

Convenient to downtown Morgantown and public transit, many Greenmont residents comm to town on foot. The original neighborhood design provides much more adequate pedestrian
connections than mor recently developed neighborhoods throughout the city.
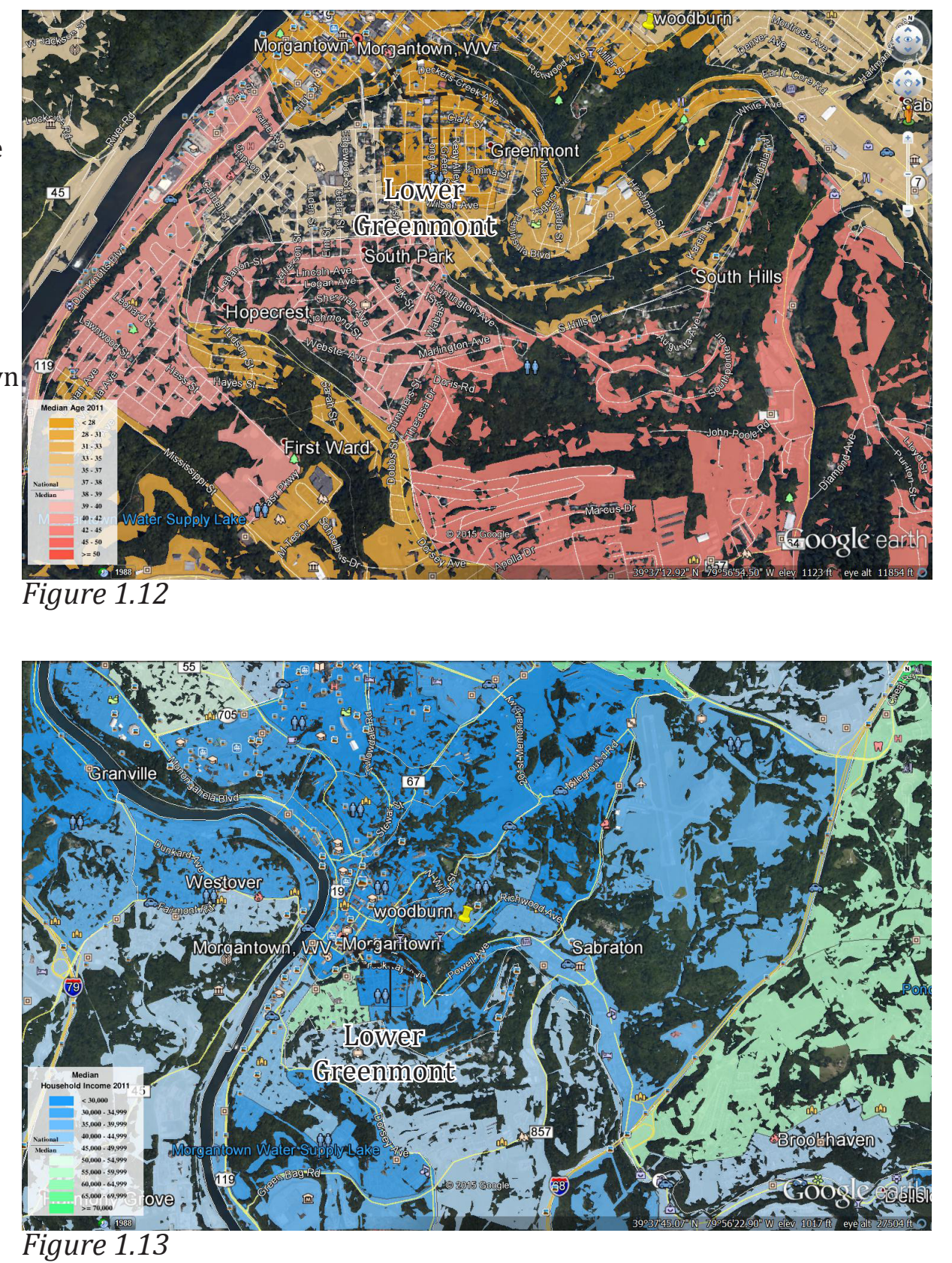

The Deckers Creek Corridor

The Deckers Creek Corridor is a valuable asset for surrounding communities. The redevelopment of the Baltimore and Ohio Railroad into the Deckers Creek Trail allows the corridor to serve the community with recreational trails and scenic with recreational trails and scen views of the creek. Subsequent development surrounding the rail-trail which inproves views from the trail, provides access to the trail, and the water quality of Deckers Creek will contribute to the corridor's transformation into a to
a cohesive recreational and wildlife

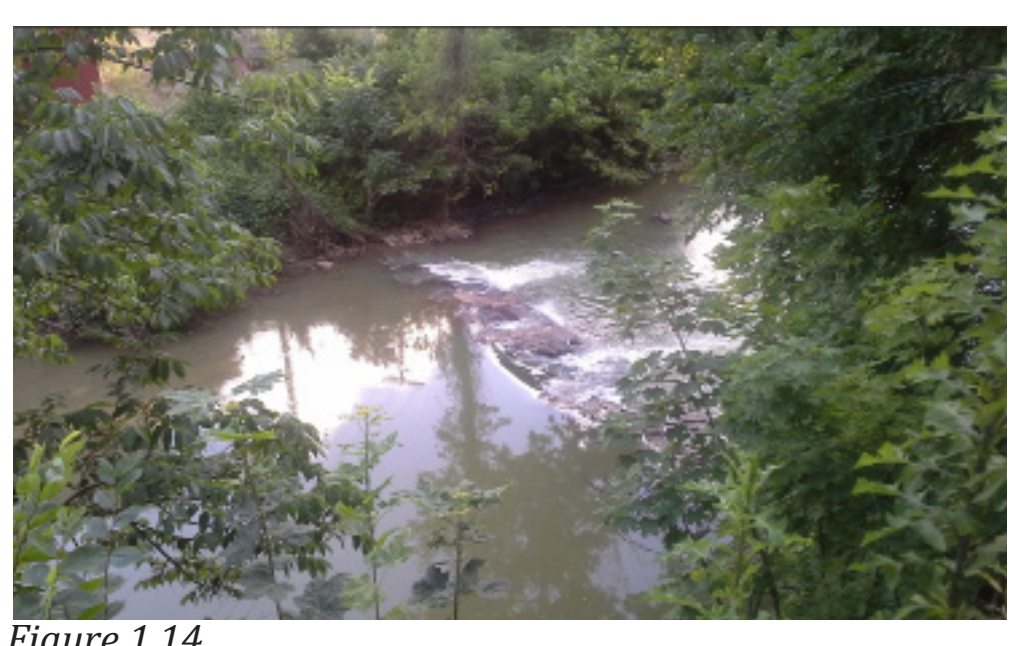

zone in the heart of Morgantown. The Waterfront Redevelopment area was delineated to include properties within the recommended 150' riparian buffer area, so that the area may be redesigned for recreational and wildlife enhancement. Also within the redevelopment area, are highly visible and public areas which may provide access to the enhanced recreational and wildlife corridor.

\section{Recreational Opportunities}

The installment of the Kerns Crossing Pedestrian Bridge will attract pedestrians through Lower Greenmont to access the trail. The Lower Greenmont Waterfront Redevelopment Design will take advantage of commercial and quality of life opportunities provided by connecting the neighborhood to the trail network by serving as a trail destination for trail users. Like the Seneca Center, the adaptive reuse of the historic Monongahela Power Station could transform the industrial structure into an iconic community center by which folks throughout the area identify the neighborhood. Existing infrastructure can be incorporated into unique park and open spaces, that provide rich Existing infrastructure can be incorporated into unique park and open spaces, that provide rich commercial areas in Lower Greenmont as well as to the trail from residential areas.

Waterfront Redevelopment Limitations

Two issues impacting the effectiveness and appeal of the wildlife and recreational corridor are derelict waterfront spaces, bare riparian buffer areas, and water contamination. Barbed wire fences, large areas of paved surfaces, electric infrastructure, and automobile rubble make the neighborhood industrial properties unsightly and uninviting. The lack of native plant species in the riparian buffer zone, detract from the waterways aesthetics and ability to support a diverse wildlife ecology. Furthermore, debris, bacteria, and contaminants from upstream impair the creek's water quality. Redevelopment that identifies and exposes these issues, demonstrates remediation plans, and tracks the plans' progress may educate the community about water quality and improve public perceptions of the waterway.

\section{Existing Waterfront Development}

The Deckers Avenue Power Station has been identified as blighted and is creating a barrier between the Lower Greenmont neighborhood and the Deckers Creek Corridor. The station is operated by First Energy and services electricity to 1900 homes. There is a 20' strip of vegetated, riparian buffer on the property, between the power station and Deckers Creek. Much of the existing 


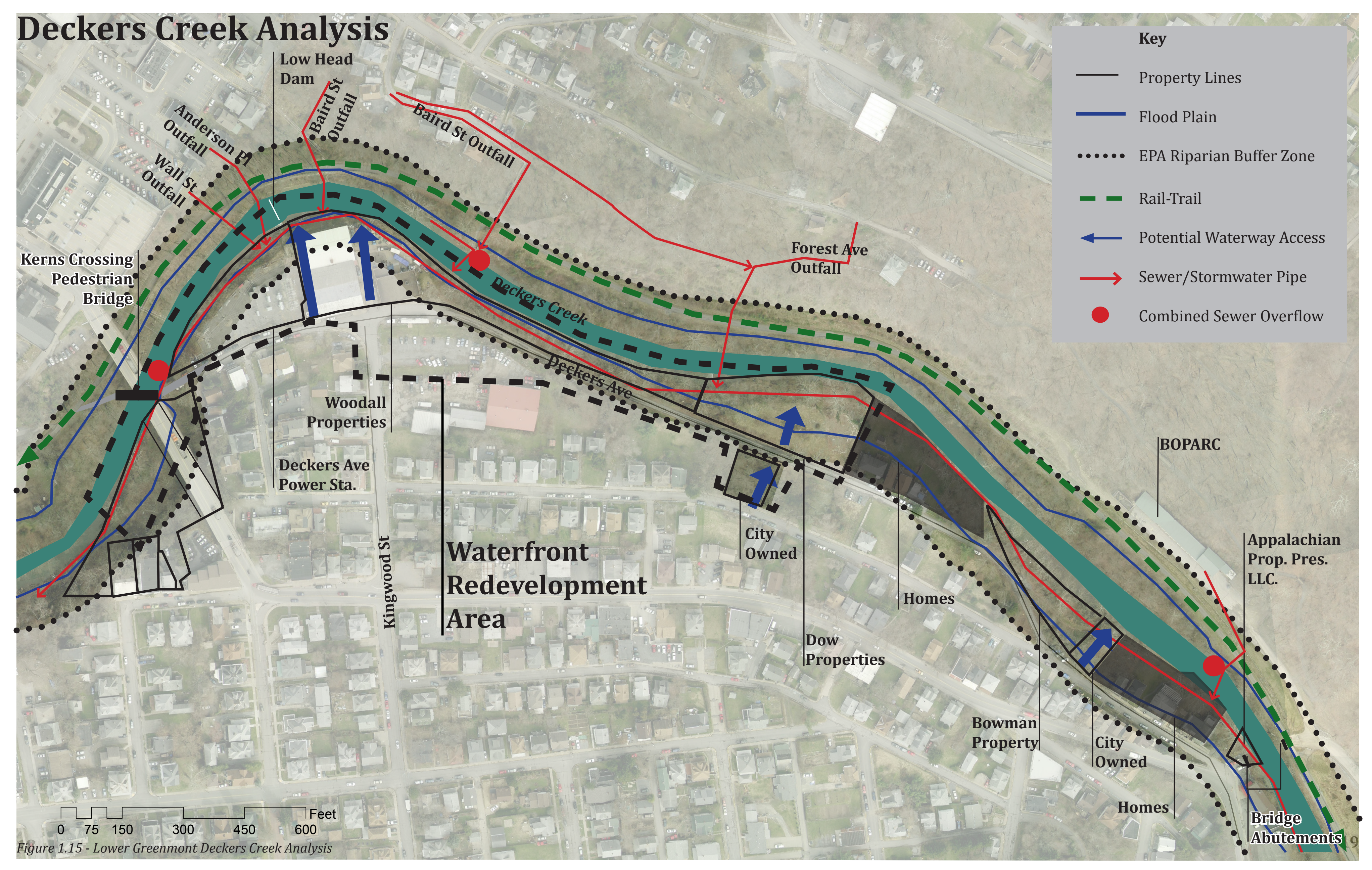




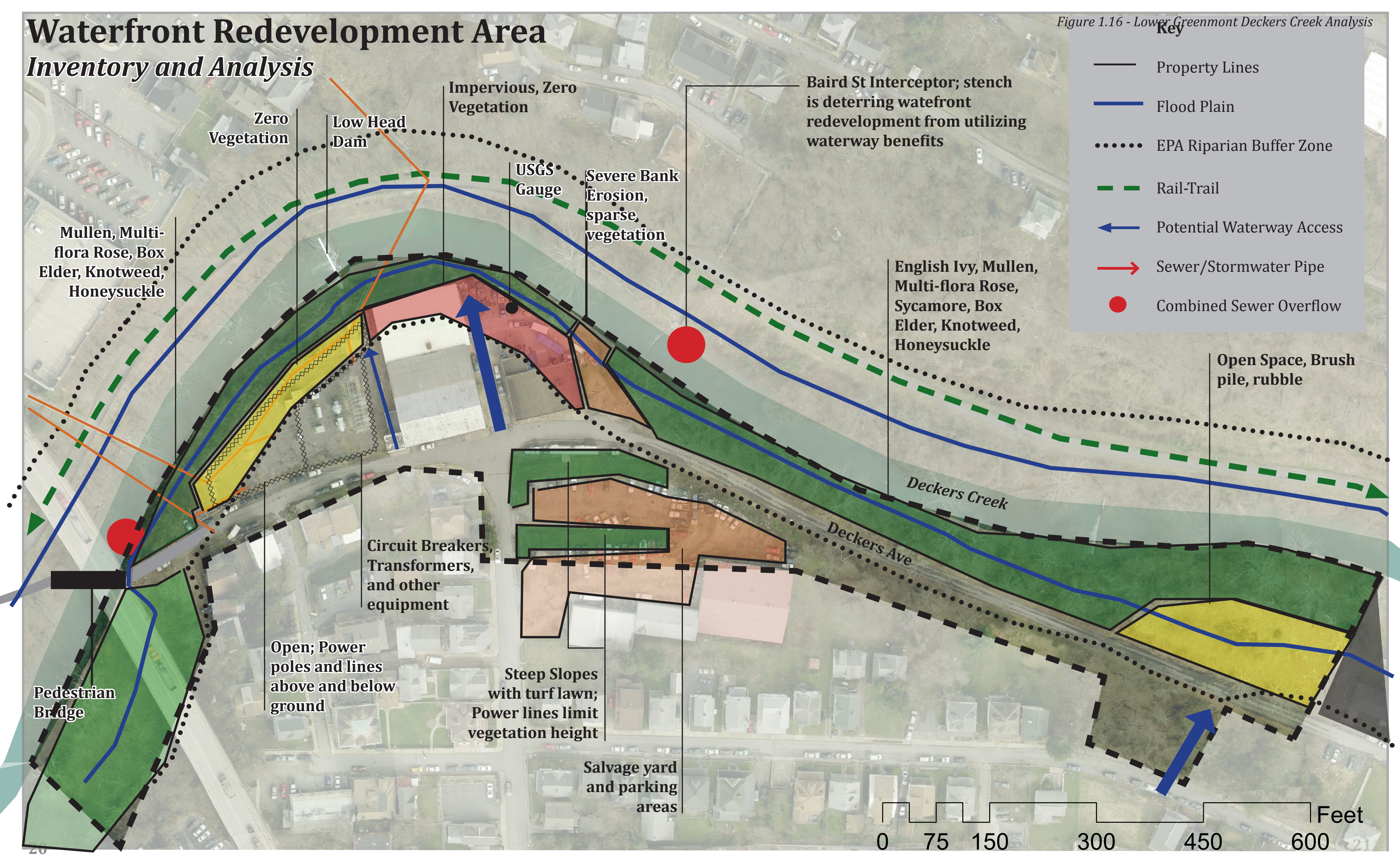


vegetation is Japanese Knotweed and other invasive species. The utilized portion of the $2 \frac{1}{2} / 2$ acre site is surrounded by a barbed wire fence, half of which is open with power poles and lines above and below ground. The other half has circuit breakers, transformers, and other power station equipment. The entire fenced in area is sprayed regularly to prevent any vegetation growth. There are also two sets of power lines extending from the power station and across Deckers Creek, to areas downtown. To maintain clearance for these power lines, areas below area clear cut further impacting the corridor's visual appeal and wildlife habitat.

The current Wilson Works Property was first developed to utilize the waterway for Kerns' grist mill in the 1700's (Held, 2015). Later developments utilized the waterway to provide hydroelectric power to surrounding homes and businesses. In the mid 1900's, however, a large, sheet metal building was constructed. Property use since does not seem to have featured the benefits of waterfront development. The brick Wilson Works facility houses offices in part of the building. The remainder of the building and the sheet metal structure behind the former power station is being used to store equipment for Ervins Towing Company. The white block building, also on the waterfront, formerly known as Bailey's Auto Center

\section{Riparian Buffer}

The US Environmental Protection Agency suggests a 150'vegetated riparian buffer zone, to support local wildlife. However, the streambank adjacent to the Waterfront redevelopment area has a very limited amount, if any, of streambank vegetation. Much of the existing vegetation is invasive knotweed, honeysuckle, and multiflora rose. Native plantings along the redeveloped waterfront may provide framed waterway views and enhance the wildlife and aesthetics of the corridor.

\section{Waterway Impairment}

Deckers Creek is currently on the

Deckers

due to contamingays

due to con (AMD), gartioge, and bacter

drainage (AMD), garbage, and bacterial

contamination (Schrecongost, 2005).

While the creek is contaminated with

AMD upstream from Greenmont,

existing development and activity

in Lower Greenmont is contributing

significant amounts of garbage and

bacterial contamination. Litter has been

dentified as a significant neighborhood

issue, especially toward the community's

eastern gateway. Garbage that is not

removed from city streets and properties, may be washed into the creek. The creek's bacterial contamination is caused by non-point source and point source pollution. The sources contributing point source pollution in the city are Morgantown Utility Board (MUB) Combined Sewer Overflow (CSO) outlets (Christ, 2005).

Garbage from Pennsylvania and Brockway Avenues and the identified derelict neighborhood spaces is washed from neighborhood surfaces and into storm drains, where the debris either flows through the system to enter the creek, or clogs up the stormwater system. This issue causes flooding at the neighborhood's eastern gateway nearly every time that it rains.
MUB maintains the city's drinking water and stormwater/ sewer systems. As part of the stormwater/sewer system there are 20 Combined Sewer Overflows along the banks of Deckers Creek. The influx of stormwater runoff following significant rain events causes these CSO's to dump human sewage directly into Deckers Creek (MUB, 2015). In effect, areas surrounding these CSO outlets are unappealing due to the stench of raw sewage. The reduction of stormwater runoff to these outlets will reduce the amount of contamination that enters the creek (MUB, 2015). There are $4 \mathrm{CSO}$ outlets in the Lower Greenmont Neighborhood. Therefore, to enhance the appeal and mprove the water quality of Deckers Creek through Lower Greenmont the amount of stormwater to CSO outlet numbers $006,007,035$, and 038 .

MUB suggests the installment of green infrastructure to reduce stormwater runoff (MUB, 2015). Incorporating green infrastructure through neighborhood revitalization in Lower Greenmont will reduce runoff to CSO Outlets 007 and 038 .

The CSO most directly effecting the Waterfront Redevelopment Area is the CSO Outlet 6, known as the Baird Street Interceptor. This interceptor receives outfall from areas on the downtown side of Deckers Creek including Locust Avenue, Dallas Avenue, and Baird Street.

Therefore, the installment of green infrastructure in those areas will allow the redeveloped

waterfront in Lower Greenmont to feature the creek's natural benefits in an environment free from the odor of raw sewage, in addition to improving the water quality of Deckers Creek. 


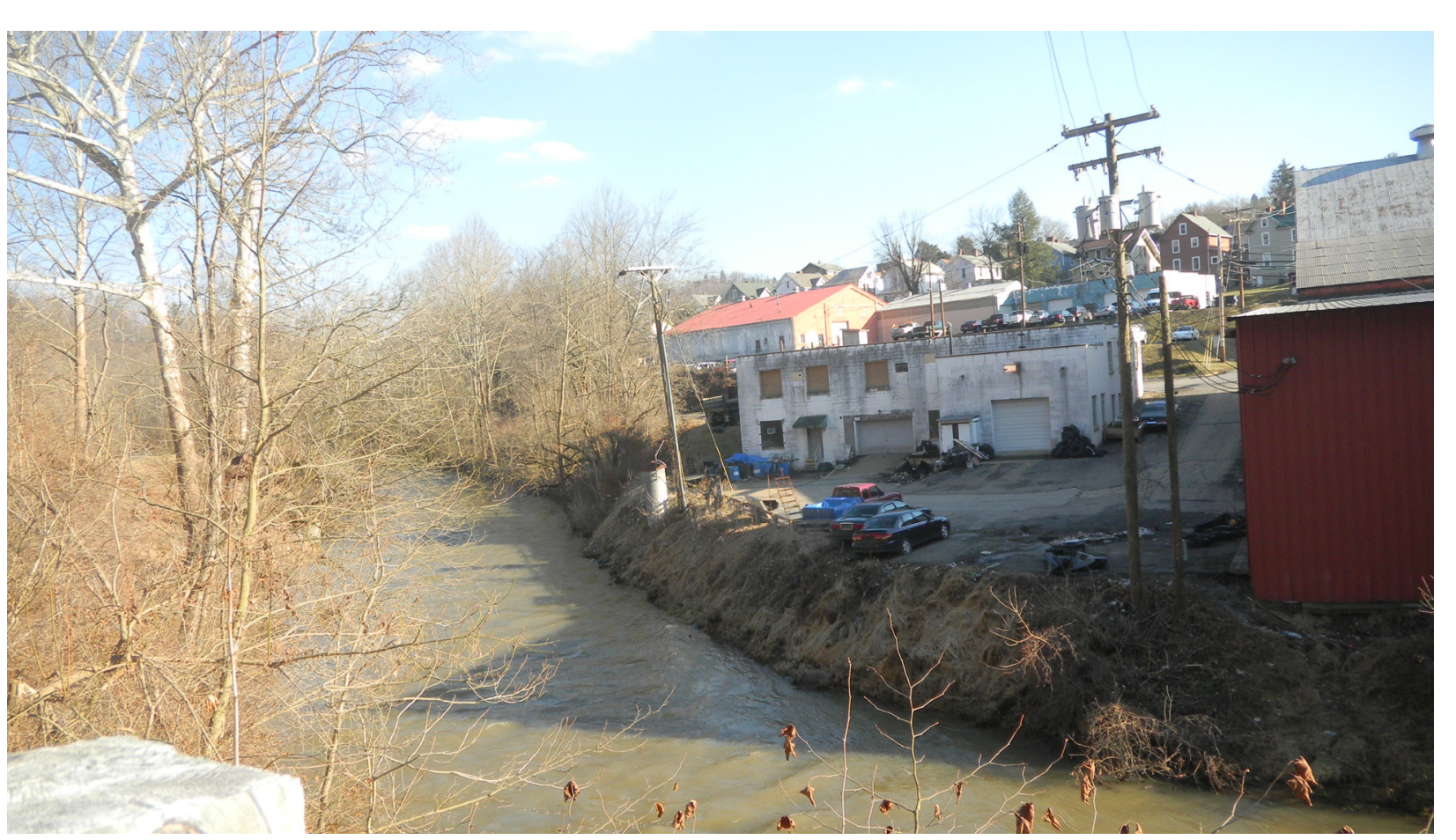

Figure 1.18 - Industrial Waterfront

The white building shown is the former Baily's Auto Repair Shop, with Wilson Works to the right and Ervin's Auto Repair and Towing in the background. This is also the location of the USGS gauge. This utilitarian waterfront development is unsightly and is negatively impacting the adjacent waterway through sediment deposition and rapid stormwater runoff.

\section{Friends of Deckers Creek (FODC)}

Friends of Deckers Creek is a local nonprofit that is dedicated to the restoration of Deckers Creek. The organization works to identify and mitigate sources of creek contamination. The organization also has a new "Shade Our Streams" Program that focuses on restoring the vegetation and wildlife habitat along the creek. FODC's Youth Action Board is an educational program for adolescents that raises awareness of waterway health issues and human impacts on them.

A 2005 article released by FODC titled Local Economic Benefits of Restoring Deckers Creek: A Preliminary Analysis demonstrates how the restoration of the water quality of Deckers Creek may contribute to increases in money spent in commercial areas, waterfront property values and community quality of life. The article summarized a series of surveys conducted by WVU Agriculture and Natural Resource Economics Professors that determined that area households were willing to pay \$12-16 per mon for improved scents were willo reduced bacterita docunestion Service that estimated an increase of $\$ 1.16 \mathrm{mill}$. conservatively estimated nearly $\$ 1,000,000$ in adjacent property value increases. These are all in addition to difficult-to-measure ecconditures related to increased trail use, increased property values surrounding waterway areas, etc.

\section{Neighborhood Issues}

Heavy Truck Traffic

Heavy trucks currently access the City of Morgantown via

Brockway Avenue. This is a hot issue in the city because the route continues through the city's downtown, causing the noise and pollution associated with the trucks to impact offices, businesses, and visitors. Groups within the city including folks from the GNA have been working to reroute the traffic through the city.

The heavy truck traffic on Brockway Avenue Continuous truck traffic from early morning until evening each week day disrupts local businesses and residences along the thoroughfare. Several homes near the east end of the neighborhood are only a few feet away from the road. Furthermore, emissions from these trucks is degrading community air quality and appearance. Traffic calming and street enhancement measures are needed to improve neighborhood safety and aesthetics along this key commercial corridor and neighborhood thoroughfare.

\section{Stormwater Runoff}

Impervious surfaces prevent stormwater from infiltrating the soil hroughout the neighborhood area. So, rather than water being Gittered by vegetation and soil on a sradul path to the creeng

filtered by wegetion and soil on a sad reak,

rapidly flows over surfaces and into the neighborhood's stormwater system. In addition to causing the city's combined sewer stornwater system to overhow, this degrades the water table health by inhibiting groundwater recharge and causing the creek to rapidly rise and fall following rain events.

As referred to by the MUB website, the US Environmental Protection Agency suggests several green infrastructure techniques for runoff reduction. Bio-retention areas can capture runoff from impervious surfaces. Stormwater that drains into bio-swales, rain gardens, and other bioretention areas slowly infiltrates into the ground, promoting groundwater recharge. Furthermore, bioretention areas are typically planted with native plant species that filter water and provide wildlife habitat. The installment of bio-retention areas throughout the developed areas surrounding rivers and streams will promote waterway health by reducing runoff, filtering stormwater, mproving water quality, and slowing its path to the creek, stabilizing healthy water levels.

\section{Garbage}

Litter and garbage bins have a significant presence throughout the neighborhood. Each household has separate garbage and recycling bins that are placed out on the sidewalks one day a week for picked up. These bins occupy a significant a week for picked up. These bins occupy a significant amount of space in the densely developed residential neighborhood. Furthermore, bins often clutter the sidewalks throug the week. Litter that collects along the roads and in neglected spaces is a significant issue contributing to negative site perceptions and clogged storm drains. Pedestrian Infrastructure

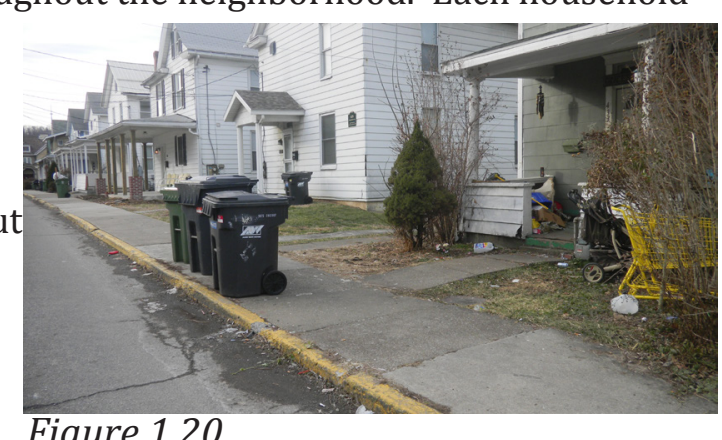

Figure 1.20 

The neighborhoods close proximity to Downtown Morgantown and Wes Virginia University's a significant amount of pedestrian transportation throughout the

peing nelghborhood. Mainten and improvennents infrastructure will in nfrastructure willinprov neighborhood quality of life and encourage more pedestrian activity. Pedestrian crossings ar

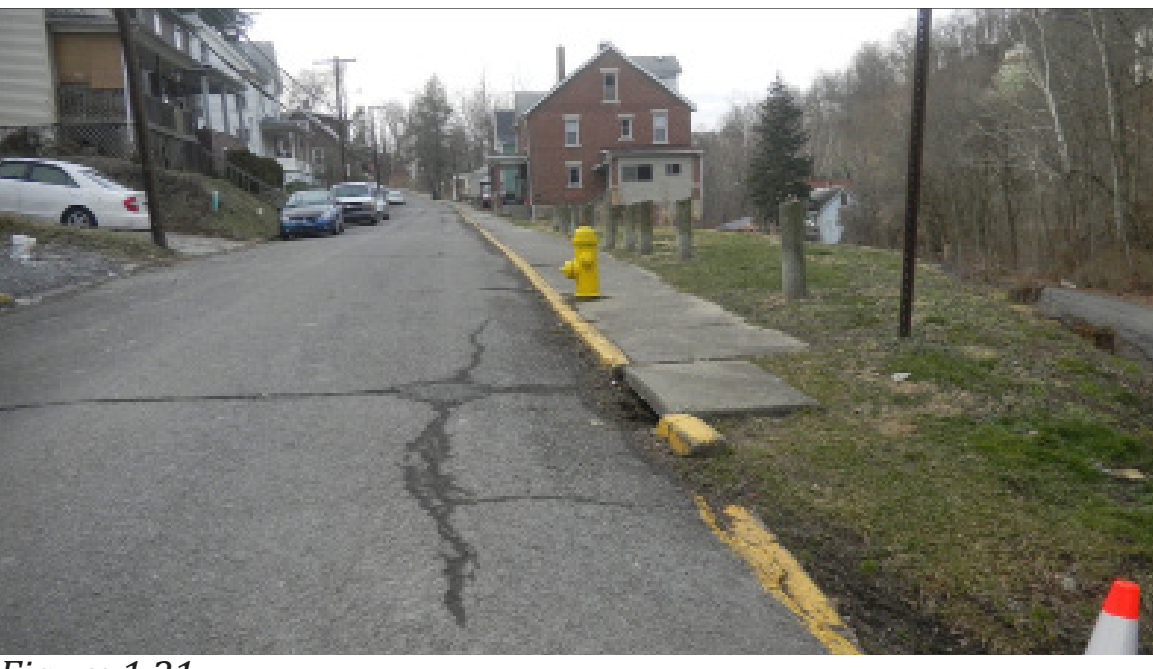

Figure 1.21

pect, and ietro Street fail to direct pedestrian traffic and further detract pedestrians from the neighborhood.

\section{Derelict Spaces}

Underutilized and under maintained outdoor spaces such as the areas under the Walnut Street Bridge on Pennsylvania have become opportune have becons dvenues (ligh such as burning littering such as burning, littering and camping. Evidence of these activities causes the spaces to be perceived as unsafe and unsightly. Parking

Commercial services once provided along Brockway Avenue and

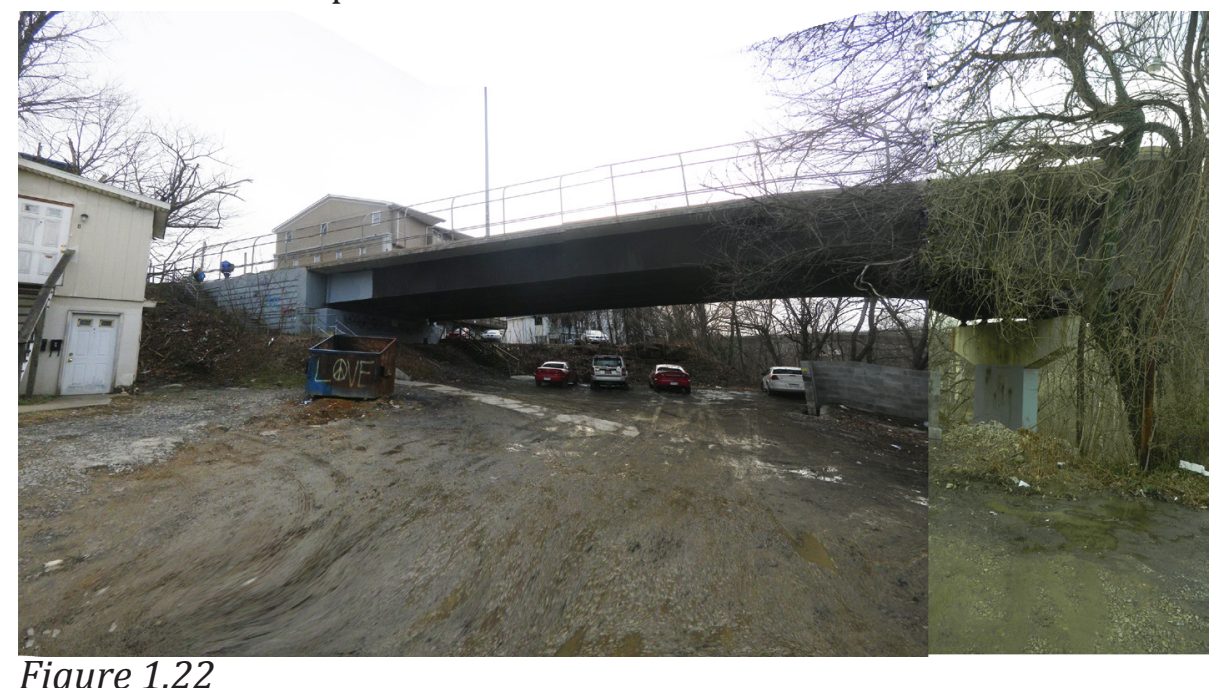

Figure 1.22
The original layout of Lower Greenmont provides adequate pedestrian access throughout the area.

Kingwood Street, are now very limited. This contributes to the need for residents to own personal vehicles and to travel to suburban areas to purchase everyday goods and services. $A$ high number of personal vehicles in this densely populated urban area has resulted in a lack of parking areas throughout the parking areas thoughout the neighborhood, forcing vehicle own to park in unauthized Towing. Furthermore, Ervins Towing is under contract with several neighborhood landowners
and often removes unauthorized

vehicles throughout the neighborhood at a large expense. Therefore, in addition to the expenses associated with owning, operating, and maintaining personal vehicles, many neighborhood

residents must also deal with the added expenses of parking tickets and towing fees.

\section{Unfavorable Commercial Property Use}

The Ervin's Auto Repair and Towing business occupies much neighborhood space in Lower Greenmont. The property has two large parking lots, a smaller parking lot, a salvage lot, and three large structures. The business also utilizes the aforementioned spaces at the Wilson Works

Deckers Avenue is a narrow road. Large trucks on Deckers Avenue take up more than their share and run other vehicles off of the road. -Shane McManus

Deckers Avenue Property Manager facility. Furthermore, Ervin's tow trucks are the majority of the traffic on Deckers Avenue, and frequently park in the space between the former Baileys Auto facility and the streambank between the fhe heavy trucks on this unpaved unvegetated, to the east. The heavy trucks on this unaved, unveget and contributing to site degradation.
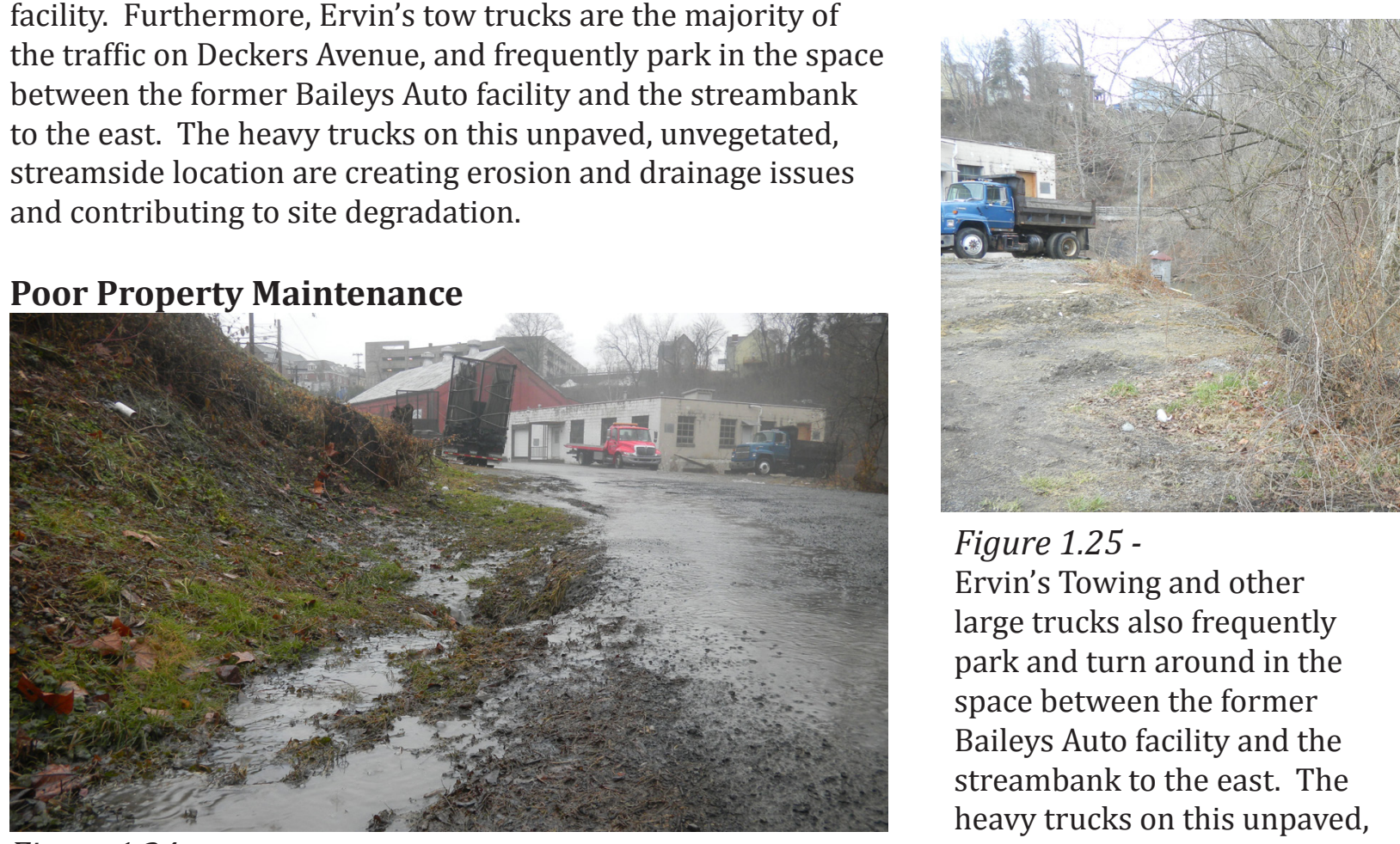

Figure 1.25

Ervin's Towing and other large trucks also frequently park and turn around in the space between the former Baileys Auto facility and the streambank to the east. The heavy trucks on this unpaved unvegetated, streamside Figure 1.24

The pipe shown on the left carries drainage from the properties above. Colorful, petroleum-looking substances are often location are creating erosio and drainage issues and contributing to site degradation. 
Many of the homes in Lower Greenmont have gutters in disrepair, contributing to property

devaluation due to foundation damage

associated with poor drainage.

Furthermore, most lawns are minimally

maintained and are littered with

pet waste and/or garbage. This

neighborhood norm offers little incentive

for property enhancement to landlords

and residents.

Envisioning a restored waterway, vibrant with human and ecological life..

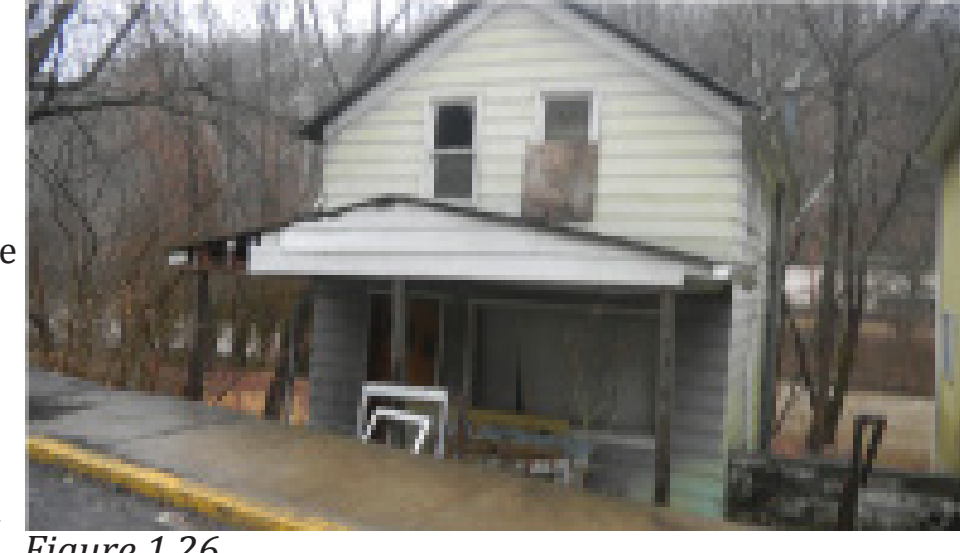

Figure 1.26
Figure 1.27

Residents living in the neighborhood area often struggle to find parking spaces near their homes. Figure 1.30 shows a vehicle being towed to Ervins Towing and Auto Repair. It appears that the vehicle is being towed for parking out of the parking zone hat ends at the location of the sign.

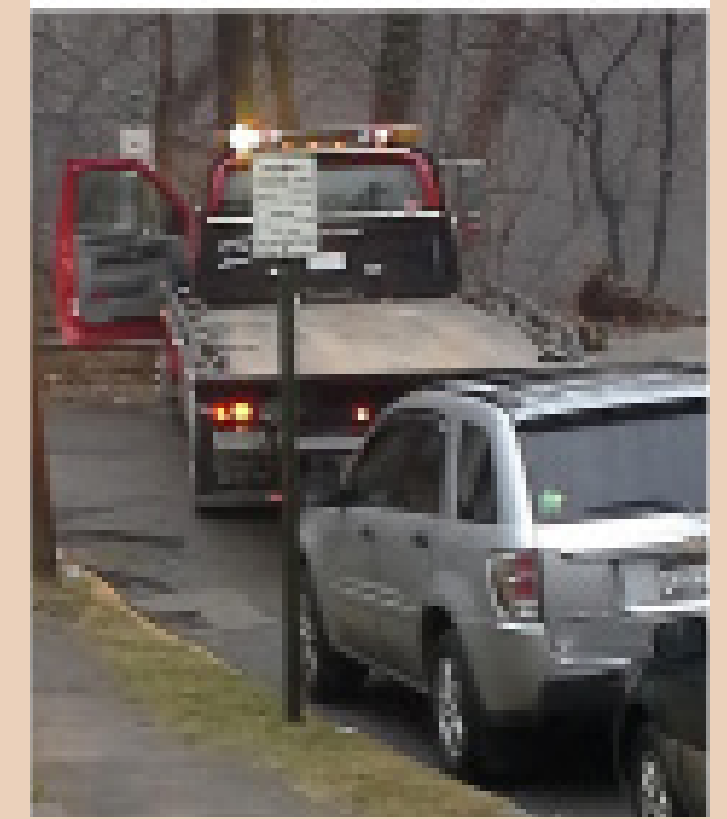

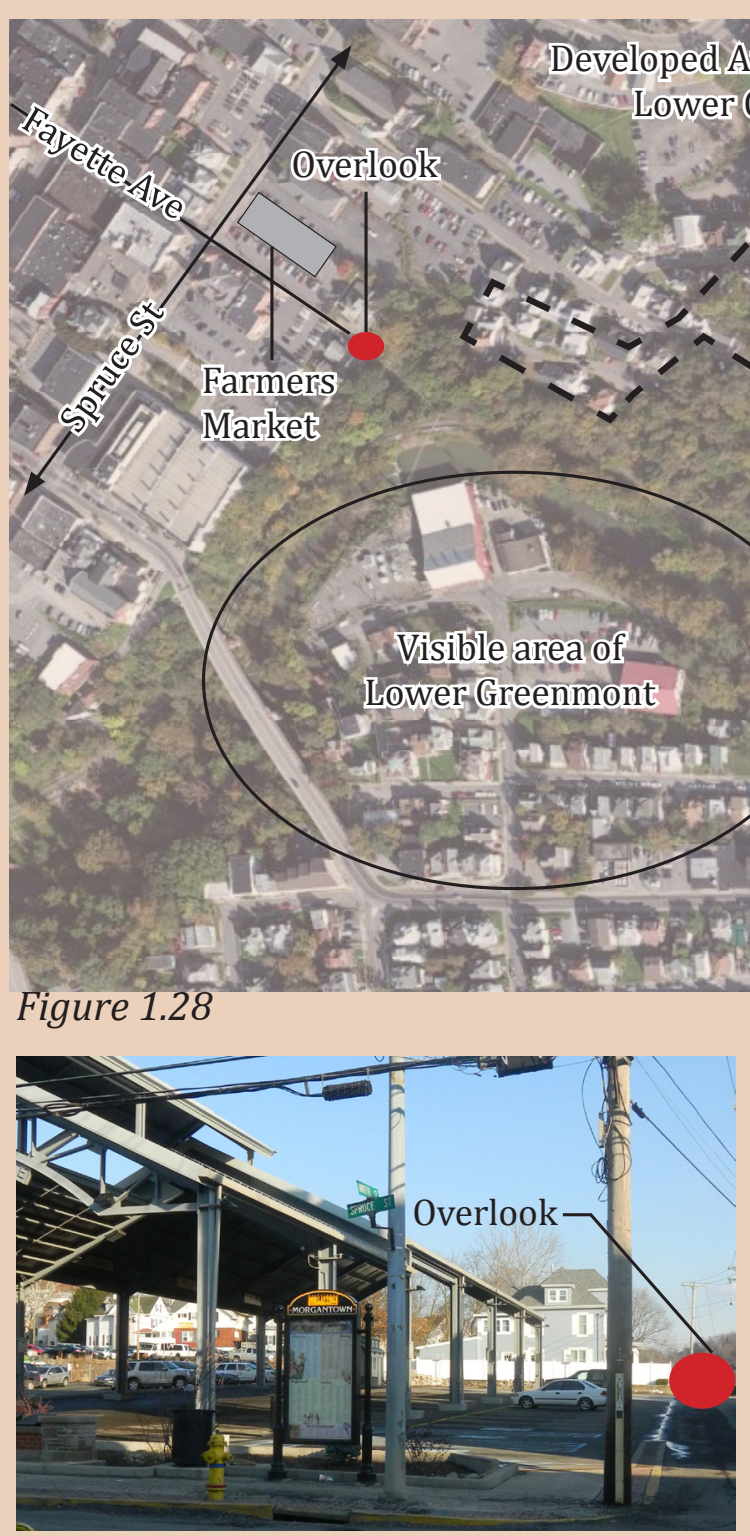

Figure 1.29
Figure 1.28
An overlook at the end of Fayette Avenue by the Farmer's Market downtown offers a view of Deckers Creek and Lower Greenmont. Downtown enhancements of this overlook area and aesthetic this overlook area and aesthetic
enhancements of the industrial enhancements of the industrial to improved community character.
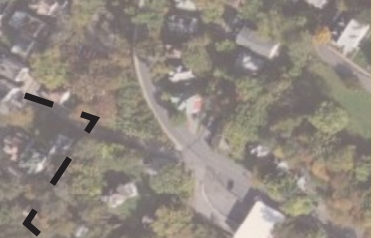

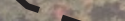

$2-3$
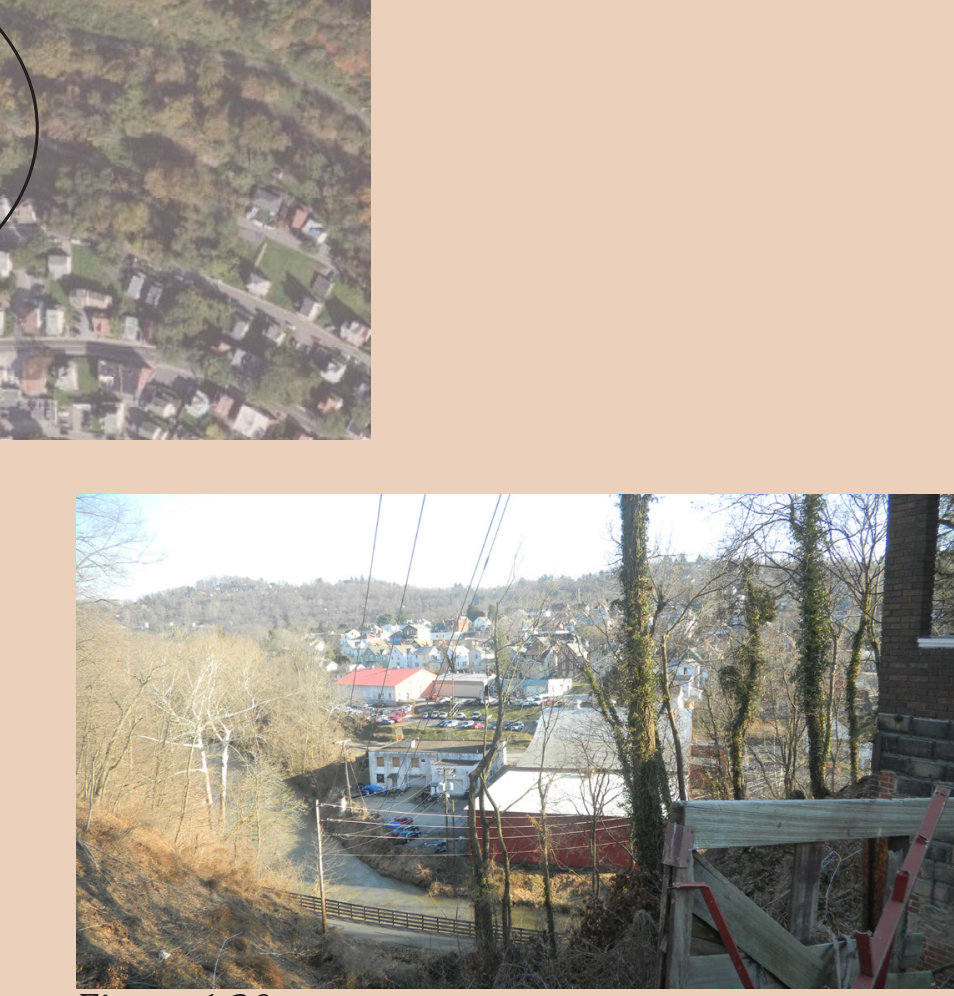

Figure 1.30 


\section{Chapter 2 Project Mission}

\section{Vision}

Neighborhood enhancement that uses stormwater management as a framework for redevelopment will reduce stormwater runoff, provide wildlife habitat, and increase pedestrian safety, as well as improve pedestrian connections from commercial and recreational areas. Green infrastructure will enhance commercial spaces, attracting local businesses needed to service everyday human needs. dditional neighborhood commercial facilities will lessen residents' needs to own personal vehicles, relieving residents from the costs associated with vehicle ownership and mitigating neighborhood parking congestion. The community's increased pedestrian-oriented commercial centers wil attract neighborhood residents to supporting local businesses. The revitalization plan will reconnect the neighborhood to the adjacent Deckers Creek with recreational facilities, enhanced views, native plantings, and repurposed properties in order to harness the redevelopment potentia of the community's natural and developed areas.

\section{Project Goals and Objectives}

Promote the neighborhood's residential appeal:

Enhancing derelict public spaces

Repurposing commercial spaces

Improving pedestrian infrastructure

Featuring the creek for aesthetics and recreation

Alleviating the need for additional parking

Reverse the downstream impacts of existing development:

Reusing underutilized infrastructure

Restoring natural waterway ecology

Slowing and treating stormwater runoff

Proposing green infrastructure

mprove the local economy:

Repurposing underutilized industrial properties

Proposing beneficial commercial facilities

Promoting locally owned businesses

Encouraging owner-occupied residential development

\section{Chapter 3 - Literature Review}

\section{Theoretical Framework:}

To define the design approach of the Lower Greenmont Revitalization Featuring Deckers Creek the design theories of Randolph Hester, Garrett Eckbo, and Elisabeth Meyer were considered and adapted. Each theorist's view, as summarized in Simon Swaffield's Theory in Landscape Architecture, serves as a guideline for project inspiration and development. In Randolph Hester's 1974 publication Community Design, he stresses the importance of site design to serve site users. He explains that site designers often design spaces to serve site owners or their own ethics, resulting in spaces that do not benefit the site users. Hester suggests that the alternative to this proctice of design againt the people practice of design against the people, is for designers to inplenent design with the people by involving site users in the design process. By doing this, designers analyze citizen input to identify the real issues with the site and the underlying design needs. This approach may be challenging ecause it often results in the need to advocate for a dife hand in order to arrive at a successful solution.

Like Hester, Garrett Eckbo stresses the importance of in depth site analysis to identify necessary site programming for successful site designs. He encourages the site designer to "analyze the past in pre present for the future", and to find inspiration "around you in space and behind you in time". To utilize this approach, the designer must patiently observe the site to be designed in order to analyze its strong points and issues to be improved upon.

Furthermore, in Elizabeth Meyer's 1997 document, The Expanded Field of Landscape Architecture, she also stresses the importance of thorough site inventory and analysis. She encourages site designers to "collaborate with the site", and to let the site speak for itself. This can be challenging
for designers who are often quick to interject design suggestions, but will ultimately lead to more successful design solutions that address the unique issues related to specific sites. To achieve this, Mejer suggests that the designer consider a site's previous design and the ethics and thery behin that as well as the adaptations and improvements which have occurred on the site over time. 


\section{Applied Framework:}

In order to apply these design approaches to the proposed urban infill and redevelopment project, site assets and sere identified based on thoroug site and neighborhood analysis. The site, originally developed over a century ago, has been redesigned and repurposed over time. Considering the development and use of the space since development will lead to a site design which does not intrude upon the evolution of the site's perception and use. The site inventory and analysis was conducted throug multiple site visits, interviews with project stakeholders, and collaborative stakeholder exercises.

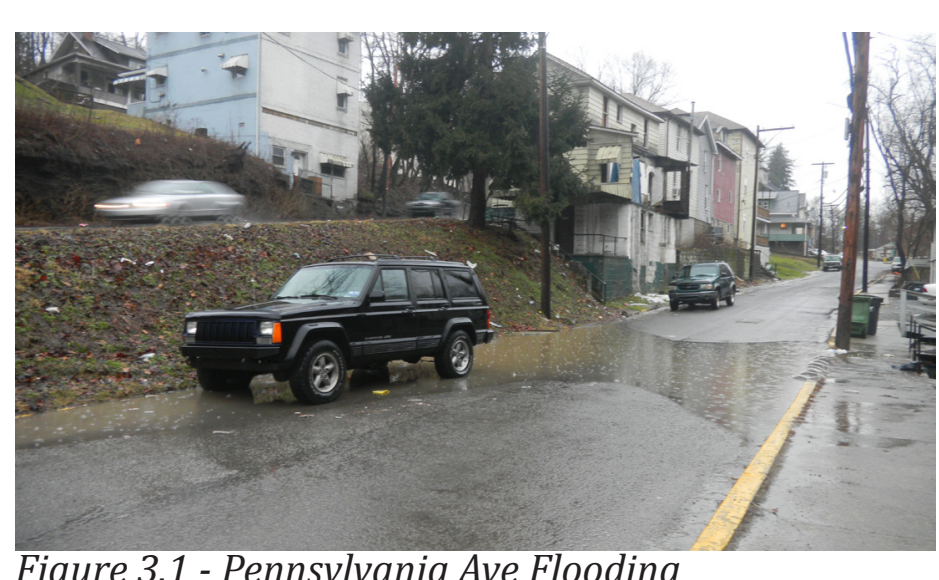

Figure 3.1 - Pennsylvania Ave Flooding

Residents claim that storm drains P7 and P8 flood Pennsylvania Ave and nearby homes every time it rains. MUB technicians claim that removing garbage from the storm drains solves the problem. Residents claim that water does not drain even after garbage removal.

Hester advocates site design for the users rather than the property owners and designers. This concept is very relevant with respect to the identified derelict spaces throughout the site that are

seemingly neglected by landowners. The input of various site users was collected organically through regular neighborhood walks. Walks during different times of the day and weather conditions lent to a more thorough analysis of site condition One afternoon, a resident living close to the proposed pedestrian bridge hysterically expressed her concerns about the potential loss of privacy and increase in neighborhood crime that could result from the bridge installment. Furthermore, on a rainy 列 ne of the resids the flooding 作 torm drains.

Another great resource for site user inventory and analysis was the local neighborhood association Within the neighborhood, I was able to identify folks who were interested in different aspects of community enhancement. Some folks were interested and knowledgeable about signage opportunities, others with crime prevention, green space, recreation, etc. Unlike many of the folks that I encountered throughout the neighborhood, neighborhood association participants have a genuine interest in attending public meetings and articulating community needs.

A practical historical neighborhood analysis connected some of the original site developments and continued use patterns with existing site conditions. Through initial development, environmental and health issues that are high priorities of site designs today, were secondary to utilitarian site development. However undesirable, large, industrial structures, steep roads, jumbled utility infrastructure, and other practica components of life, industry, and business are identifying elements of regional and cultural character. Rather than attempting to distract from and hide these prominent features within the landscape, redevelopment which features these elements may preserve community history and expose the infrastructure needed to support urban life.

Meyer's approach to letting the site speak for itself is particularly applicable in the derelict spaces and natural areas in the neighborhood. The area below the Walnut Street bridge is often the location of couch and dumpster burnings following sporting and social events. Although mitigation measures such as dumpster relocation and fire extinguishing are often used, some residents are relentless in misusing the space.

Despite the creek's impairment, it is fairly adaptive in supporting wildlife. The riparian buffer along the industrial waterfront is very sparse and much of the existing vegetation is invasive. However, the existing vegetation is very regenerative during the warm seasons. Furthermore, Friends of Deckers Creek's efforts in recent years to make the creek "fishable by 2015", have been successful in increasing the diversity and quantities of riparian species. Design strategies which work along with natural ecological site remedies will be more successful solutions for stream restoration, and will contribute to FODC's 2020 Vision to make the creek swimmable by the year 2020 . 


\section{Chapter 4 - Participatory Design}

As an area resident that frequents the study rea, I have been able to constantly observe the space and engage with members of the community about the place. This has helped me to understand the place and the many factors that determine neighborhood development and the lifestyles that the neighborhood facilitates. Regardless of what residents need or desire for neighborhood revitalization, property owners determine property use based on personal interests while local governments, nonprofits, and activists prioritize and execute community enhancement projects based on project

In order to identify practical design solutions, I connected with various individuals and local stakeholder groups that may have interest in stakeholder groups that may have interest in networking allowed me to become aware of Figure 4.1 - Community Engagement Graphic existing plans for development and connect This graphic represents project goals as related to the with individuals who are "in the know" in terms of community activity. The stakeholder groups that have contributed in some part to this project include: Friends of Deckers Creek (FODC) The Greenmont Neighborhood Association (GNA), The City of Morgantown City Council, The City of Morgantown Developmental Services Department, Morgantown Modern, and neighborhood landowners, neighborhood residents, Morgantown Utility Board (MUB), and First Energy.

The process proved to be an interesting dance as I became aware of the significance of organic social interaction. The individuals representing the local entities have personal interests, workloads, and demeanors that affect their willingness to participate in a project. The following contrasts my expectations with my experiences working with community.

\section{Approach}

After several months of place analysis and project planning, I had intended to participate in multiple meetings with individuals associated with local stakeholder groups, and host a large, open invitation community event. I intended for the project to include the same sort of community engagement and place analysis that Randy Hester facilitated in Manteo, North Carolina in his 1985 article, Subconscious Landscapes of the Heart. The project also highlights some of the same key principles such as using "Sacred Structure", the network of places that the residents find to be important, "as both a means to preserve the local culture and the foundation for new development. However, due to differences in community needs and characteristics, my community engagement approach differed from Hester's.
Who is invited to participate today?

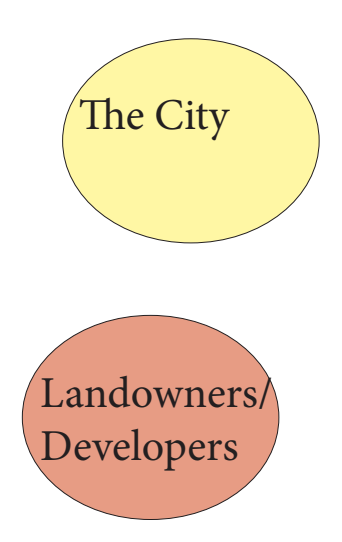

Figure 4.2 -Invitee Graphic

This graphic was displayed at the visioning event to clarify how invitees for the event were chosen.
With a project timeline from January to May. 1 initiated project engagement by connecting with the various entities individually. For each connection, I predetermined broad topics based on my understanding of the organization and $/$ r of the onganization andor indivisusion. This allowed ne to gather information about what interests these stakeholders have in the project and what information and skills that they may be willing to offer

In January, I connected with individuals representing the various entities, and engaged in project discussion as was available. I engaged in email discussions with the utility companies, met with the

City Developmental Services Department, presented project synopses at regular FOCD and GNA meetings, and had a few meetings with interested parties at local restaurants and offices.

\section{Outcomes}

Individuals representing FODC, GNA, and the City quickly responded and demonstrated interest in participating in the project. I was able to be added to the agenda of each of their regular meeting where I presented project synopses. Each group appreciated being clued in on the project and offered invaluable project advice. Individuals suggested that I identify applicable and fundable design solutions. They also offered contact information for various individuals and groups that may be interested in offering project advice. Discussions following these meetings, allowed residents to share their various perceptions and concerns about the neighborhood.

\section{The City and Utility Companies}

Utility companies typically have multiple departments dealing with customer relations, public outreach, etc., that made connecting with the right people challenging. For instance, MUB's website provided information about stormwater best management practices and advertised a plan to reduce stormwater throughout the city, and offered a contact person to provide further information. I stormwater thoughout the city, and of ered a contact person to provide further information. I The ersent The person responded and explained that the plan was pending approval by the WV Department of Environmental Protection. I then requested a copy of the plan subnitted. The person responded with contact information for an individual in the stormwater engineering department. The second connection was less eager to respond.

I had recently met with the City's Developmental Services Department regarding a different project. 


\section{Project Map}

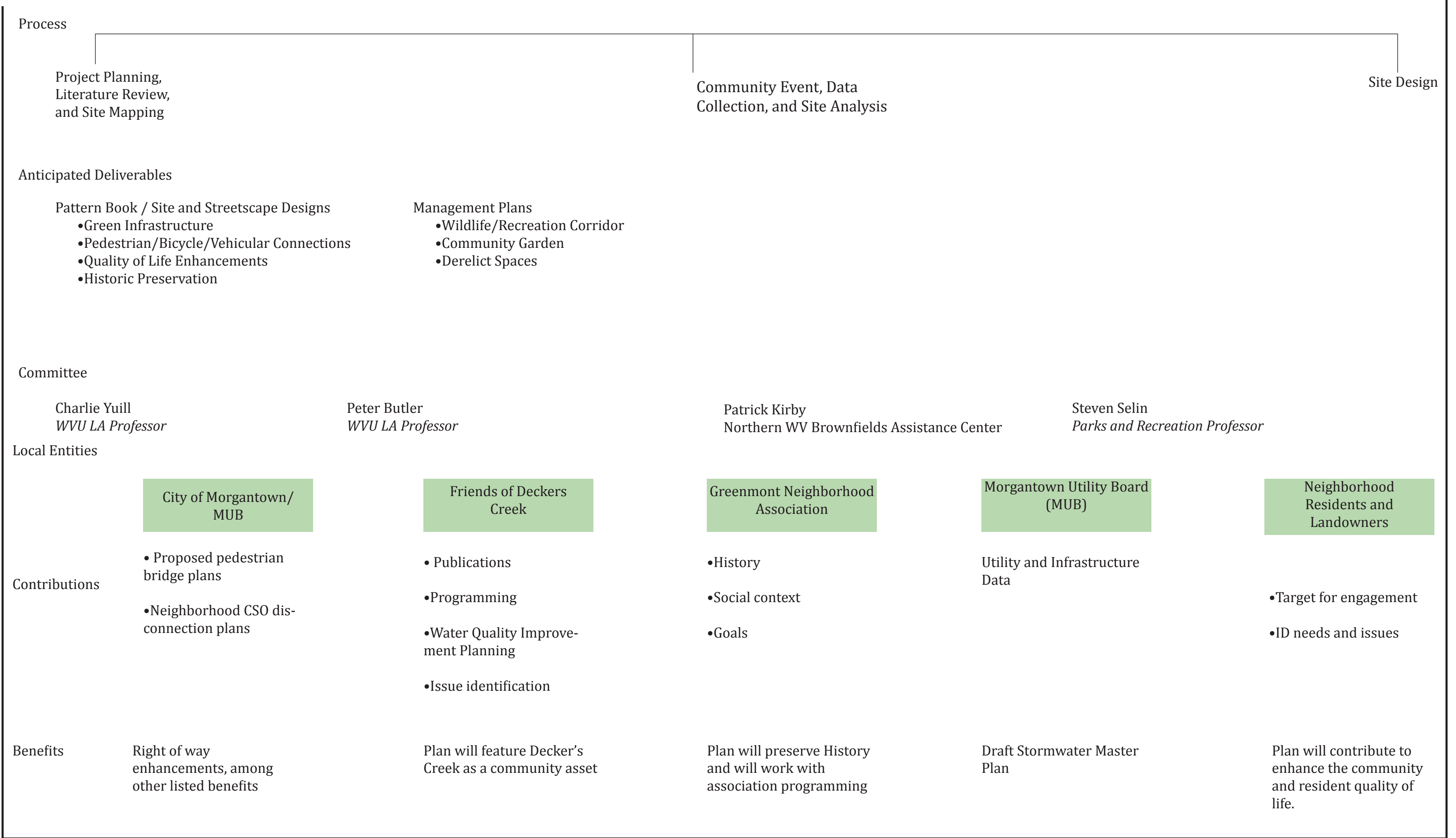


There, I was able to explain my plans for Lower Greenmont Revitalization. Because the individuals in the department were interested in the project, I was able to set up a meeting to discuss it. Like many other communities, plans adopted by the City of Morgantown, such as the comprehensive plan, transportation plans, etc. are available on the web. While these plans are generally well formatted and easily navigable, individuals working in city departments are savvy to the status, amendments, priorities, challenges, property owners, and developers associated with the plans. After a brief explanation of my project, individuals in the department were able to quickly identify and connect me with key project players including property owners and the relevant parties at the utility companies.

I explained the challenges that I was experiencing getting stormwater data from MUB to the city planner, who followed up with MUB's stormwater engineering department. The person at MUB promptly responded to my email, connecting me with another individual in the stormwater department, who supplied an AutoCAD document with all of the utility data I could have asked for and followed up asking if I needed more information. The second connection at MUB also followed up, expressing interest in viewing runoff reduction plans.

The city planner e-introduced me to the Manager of External Affairs at FirstEnergy, that he may provide information about the Deckers Avenue Power Station. I sent this person a birds eye image of the power station property that was labelled with different areas for questioning, accompanied by a list of questions about the different areas, in order to identify opportunities for the property to better serve the neighborhood. I expressed concern for the response taking longer than I had hoped, given the project timeline to the director of the Northern WV Brownfields Assistance Center who was able to follow up with FirstEnergy. I promptly received a response to my questions.

\section{Change of Course}

Several folks suggested that I connect with a previous project champion, a parks and recreation professional and local activist who had previously worked on a project in the neighborhood. When I reached out to her, she was eager to meet with me and offered much beneficial information. Familiar with the community and local stakeholder groups, she strongly suggested that the community meeting be invite-only, with structured and predetermined points of discussion. She suggested that I organize participants into groups and provide different prompts for each group. She also provided background and contact information for the owner of Morgantown Modern, a local development company that focuses on the green redevelopment of previously used structures.

Having been acquainted with the complexity of the various interests involved in this neighborhood revitalization project, and aiming to propose design solutions for the neighborhood that could be implemented, I chose to alter my plan and host an invite-only visioning, that paired key resident voices from FODC and GNA with the decision makers - city government and property owners. The decision was made early enough in the project term to invite folks 3 weeks in advance and prepare maps and discussion topics for the focus groups. However, I had already mentioned to the neighborhood association that I was planning a community visioning event. A few folks did not understand why the event was to be invitation only.

\section{Event Preparation}

Through interactions with various individuals, it became apparent to me the collaboration of key neighborhood players was necessary to determine practical design solutions. I planned and conducted the community meeting based on the West Virginia Redevelopment Collaborative model a model for community engagement geared toward brownfield redevelopment. The model pairs project champions with multidisciplinary teams to collaborate through structured engagement (WVRC, 2013).

Thoughtful planning was an important component of convincing folks to attend the meeting and gathering meaningful information once they were there. I did not hesitate to ask for advice about facilitating the event The WVRC coordinator offered much valuable advice literature, and facilitation assistance through the event I referenced the Facilitator's Guide to Participatory Decision-Making, and Building Communities from the Inside Out when establishing meeting goals and activities. Each reference offered valuable insight on the complicatedness of organic community engagement. In preparation for the visioning event, I secured a venue, sent individualized invitations via email, planned a meeting agenda, designed focus group activities, sent reminder invitations via email, planned a meeting agenda, designed focus group activities, sent reminder
emails, and compromised as needed. In order to cater the event activities and questions toward the individuals that were to attend, I requested that folks RSVP no later than 3 days before the event.

\section{Securing a Venue}

To align with my project timeline, I intended for the event to be held at the end of February. I secured the event venue at the end of January. Choosing a venue was challenging because I planned to, weather permitting, include a site walk. Therefore, I preferred for the venue to be walkable to the neighborhood. I also wanted the event to last 4-5 hours, in which case, refreshments may be in order. Folks at the GNA meeting suggested a couple of small, local churc of small, local churches. Because (her , I relied on an indidual fom the GNA to contact people in charge of the church facilt for me. When I did not receive a response for several days, I chose to seek out other options so that I may promptly send invitations. The local public library is a quarter mile from the neighborhood and has a meeting room hat I was able to reserve for free. The library does not permit food or drinks, so I chose to shorten the meeting time to 3 and a half hours.

\section{Sending Invitations}

Invitees were determined based on The Tamarack Institute's Community Reference System. Knowing that the success of the visioning was, in large art, contingent upon folks attending and that folks are often more receptive Figure 4.4 - Meeting Invitation to individualized correspondence than This is invitation was sent as an email attachment to event group emails, I sent 37 individualized attendees.

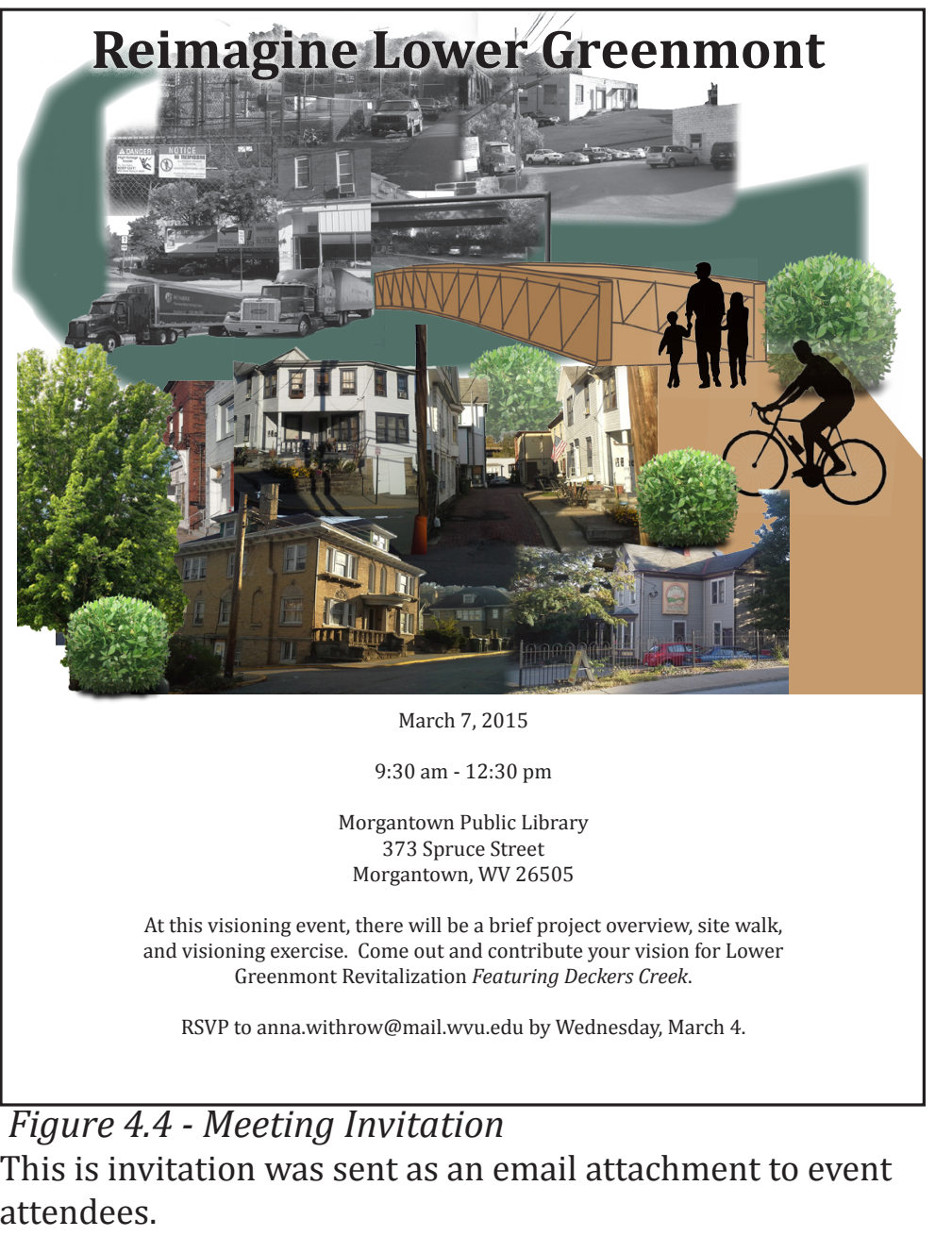


invitations via email. The body of each email invitation included an ice breaker of some kind, a synopsis of the meeting, as it related to the individuals interests, and the ways that I felt the individual could contribute to the event. Email invitations included 2 attachments: a one pager with background information and an invitation flyer with meeting time, date, and place information.

Two folks offered to post invitations on social media and/or share invitations with others. Anticipating that this may occur, I promptly responded explaining that the event was by invitation only so that folks may engage in detailed discussions about specific issues. I also explained who from their stakeholder group was invited and why and ence the nformation for any key parties that were left wh

Setting the Agenda

Valuing the time of the participants, I carefully designed event activities to engage participants the full length of the event. My original plan was to meet at the venue for a brief event introduction and to assign collaborative groups before sending groups out to do site walks through the neighborhood, with maps and discussion points throughout the walk. Upon completion of the 45 minute walk, I planned for groups to sit at tables surrounding maps and perspectives of the areas of interest, where they could discuss and make notes on the maps. I allocated 45 minutes for groups to record assets and issues, followed by 45 minutes to record opportunities for community enhancement, based on individual group prompts. To conclude the meeting, I planned for each group to present a discussion synopsis to the larger group.

An event coordinator advised that I announce that the meeting will take more time than I anticipate because folks generally like to get out of meetings early than have them run late.

\section{Determining Collaborative Groups}

I considered my project goals to determine the focus for 4 collaborative focus groups. My goals for the meeting were to connect key stakeholders for neighborhood revitalization and to identify sacred spaces, historic features, and neighborhood issues, determine desirable site uses for the waterfront redevelopment area, and recognize ecological and recreational enhancement opportunities. The four focus groups were Sacred Structure, History and Sustainability, Identity and Branding, and Recreation and Quality of Life.

As I formed the invitee list, I considered the skills that the individuals had to offer, the interests that they had in the project, and the people that they may work well with to achieve meeting goals. I simultaneously made undisclosed notes beside each invitee, listing 1 or 2 groups that the individual may work well in. This allowed me to imagine who may be in each group as I prepared maps and prompts to guide group discussions.

As folks rsvped, I assigned them to a group. Aware that folks were likely to add and drop up to the day of the event. I did not share group assignments with the participants until the start of the event. This also prevented folks from asking to work in a different group.

I learned that it is important to decide ahead of time how to divide the meeting into groups and how the facilitator will react if individuals request to work in different groups. At some focus group meetings, facitlitators provide nametags with discrete markings representing each group and announce for participants with matching markings to convene in particular locations. At the Reimaging Lower Greenmont meeting, I placed the prepared maps face down on tables so that folks could filter in and sit wherever they felt comfortable, without too much anticipation of what
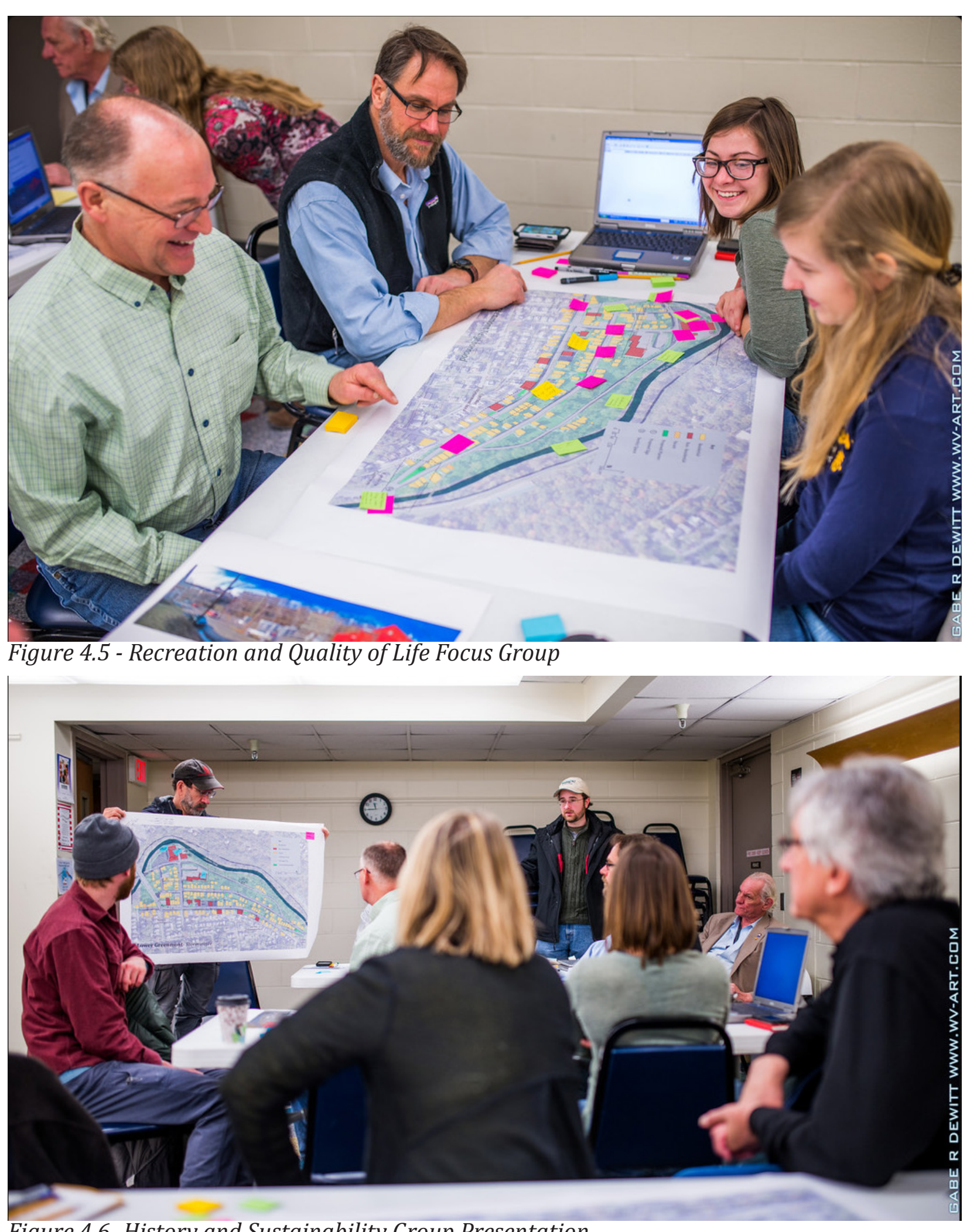

Figure 4.6- History and Sustainability Group Presentation 


\section{RSVP's}

My persistent requests for RSVP's allowed me to be aware of who intended to participate and plan accordingly. The majority of folks who attended rsvped immediately upon receiving invitations. A few folks replied that they. "The the event to their calendar". Ilearned that this statement does not constitute an RSVP. I sent a reminder ead to the entre invite list the day that the rsvp's were due and at a point severail to folks informed me that they would not be attending, Ond again, the day before the event. At that point several folks informed me that they would not be attending. One key participant, who had never before responded to $m y$ multiple attempts at communicating with him rsvped the afternoon before the event.

\section{Event Reflections}

of the 37 invitees, 16 individuals participated in the visioning event. The meeting provided a platform for Of the 37 invitees, 16 individuals participated in the visioning event. The meeting provided a platform for
individuals to collaborate on identifying neighborhood assets, issues, and opportunities for revitalization. The following pages display the event products; notes from group presentations and maps covered with post it notes followed by my synopses of group discussions based on those products.
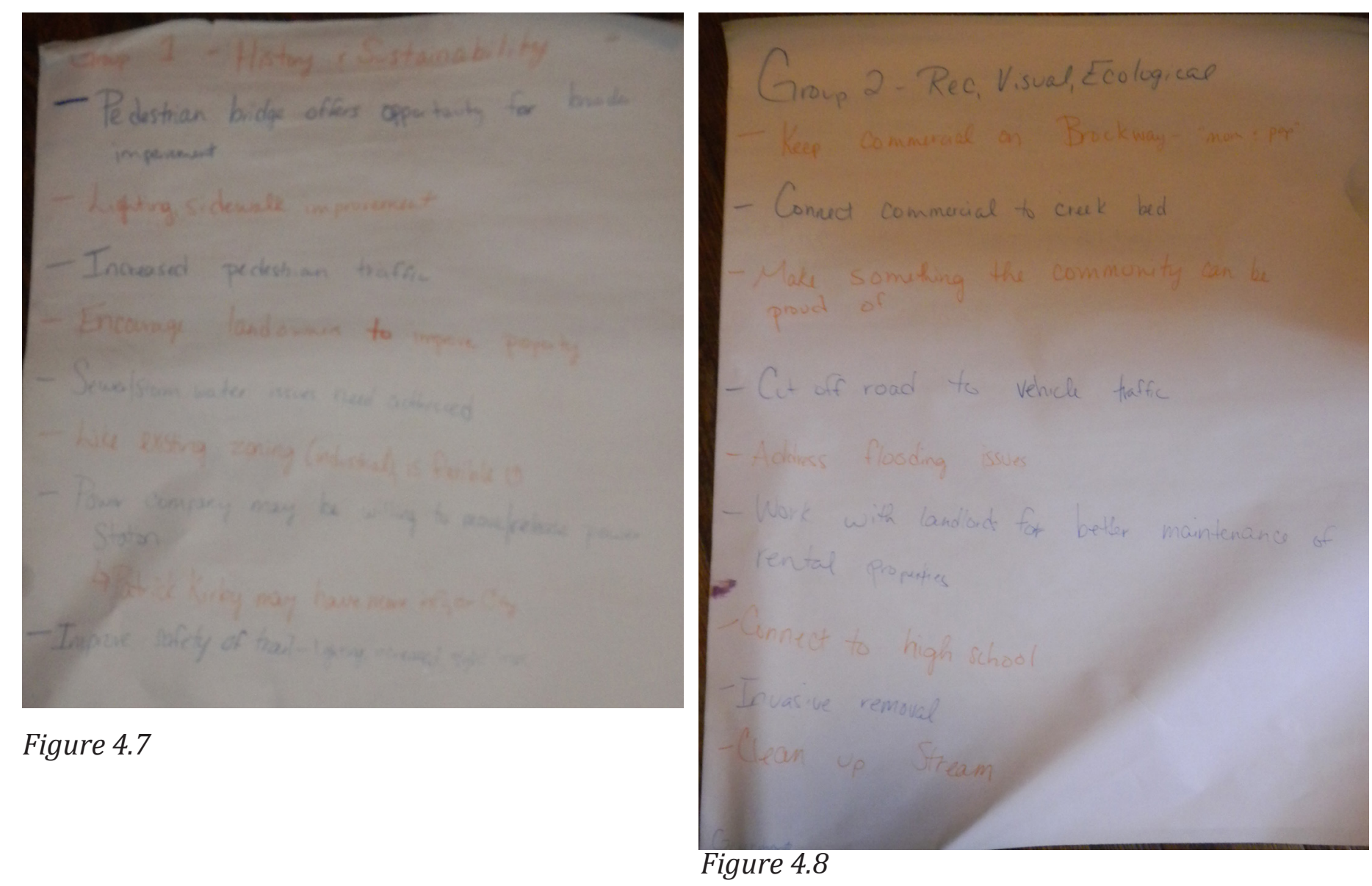

Figure 4.7

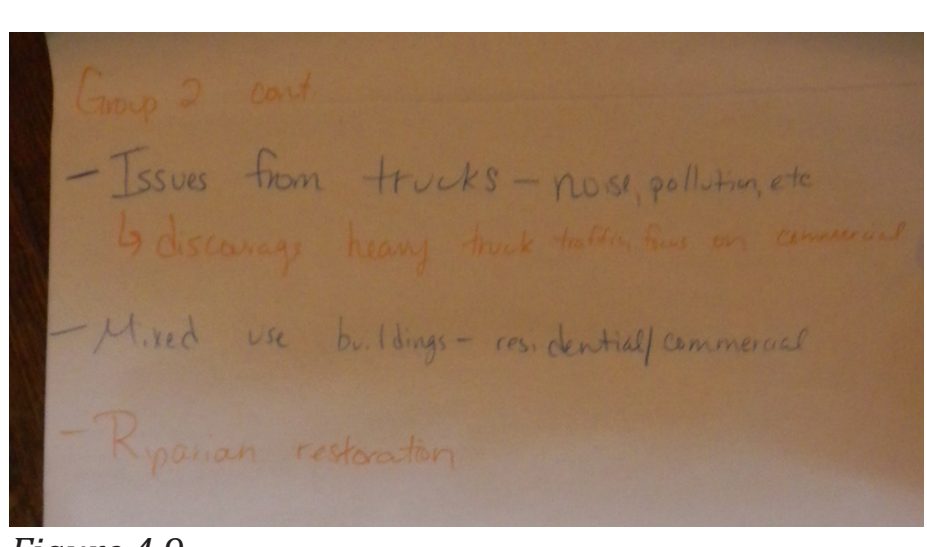


At the visioning event, groups were prompted to identify assets and issues related to people (pink), planet (green), profit (yellow), and history (blue). This added depth to group discussion and encouraged whole-systems thinking.

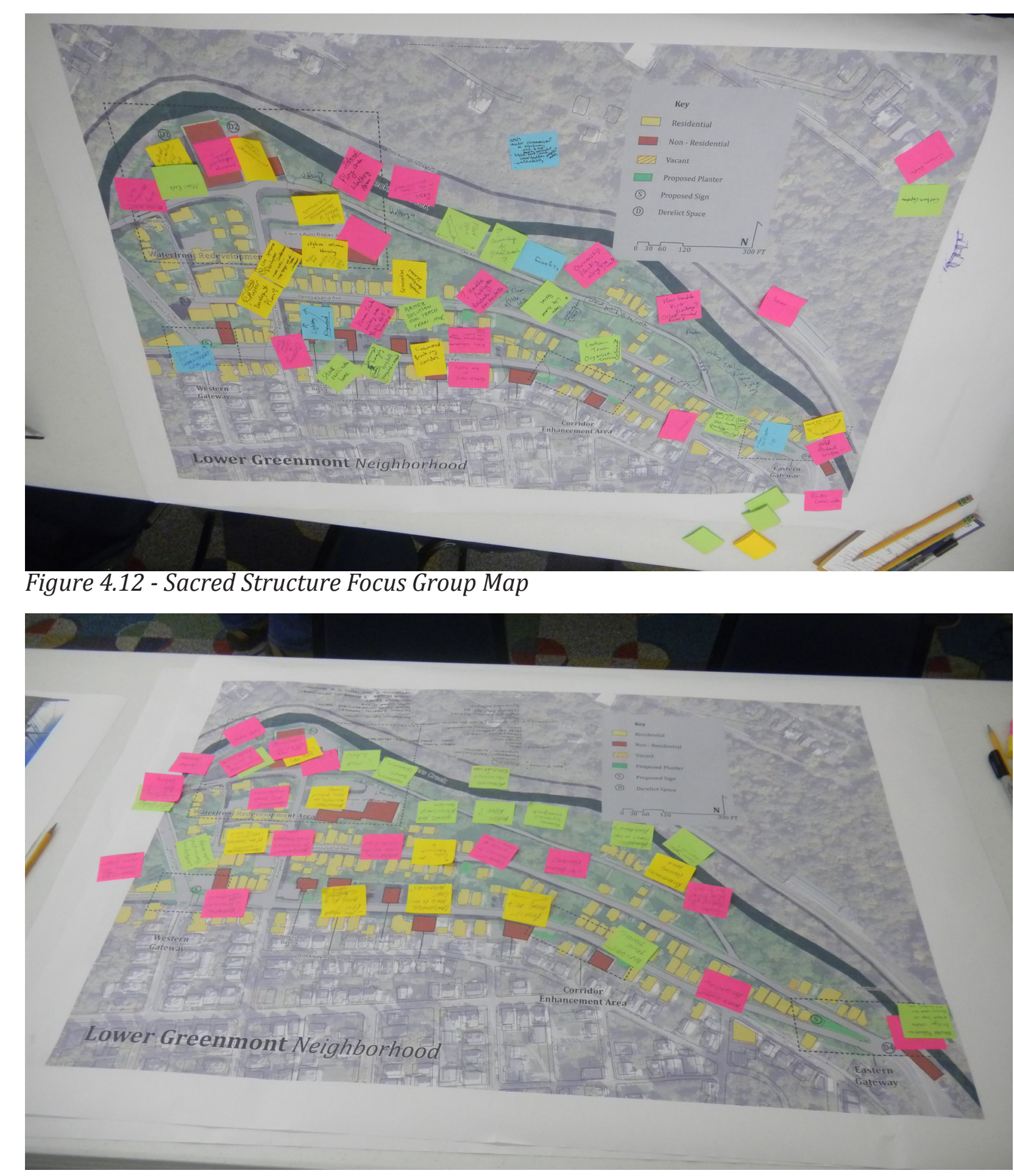

Figure 4.13 - Recreation and Quality of Life Focus Group Map

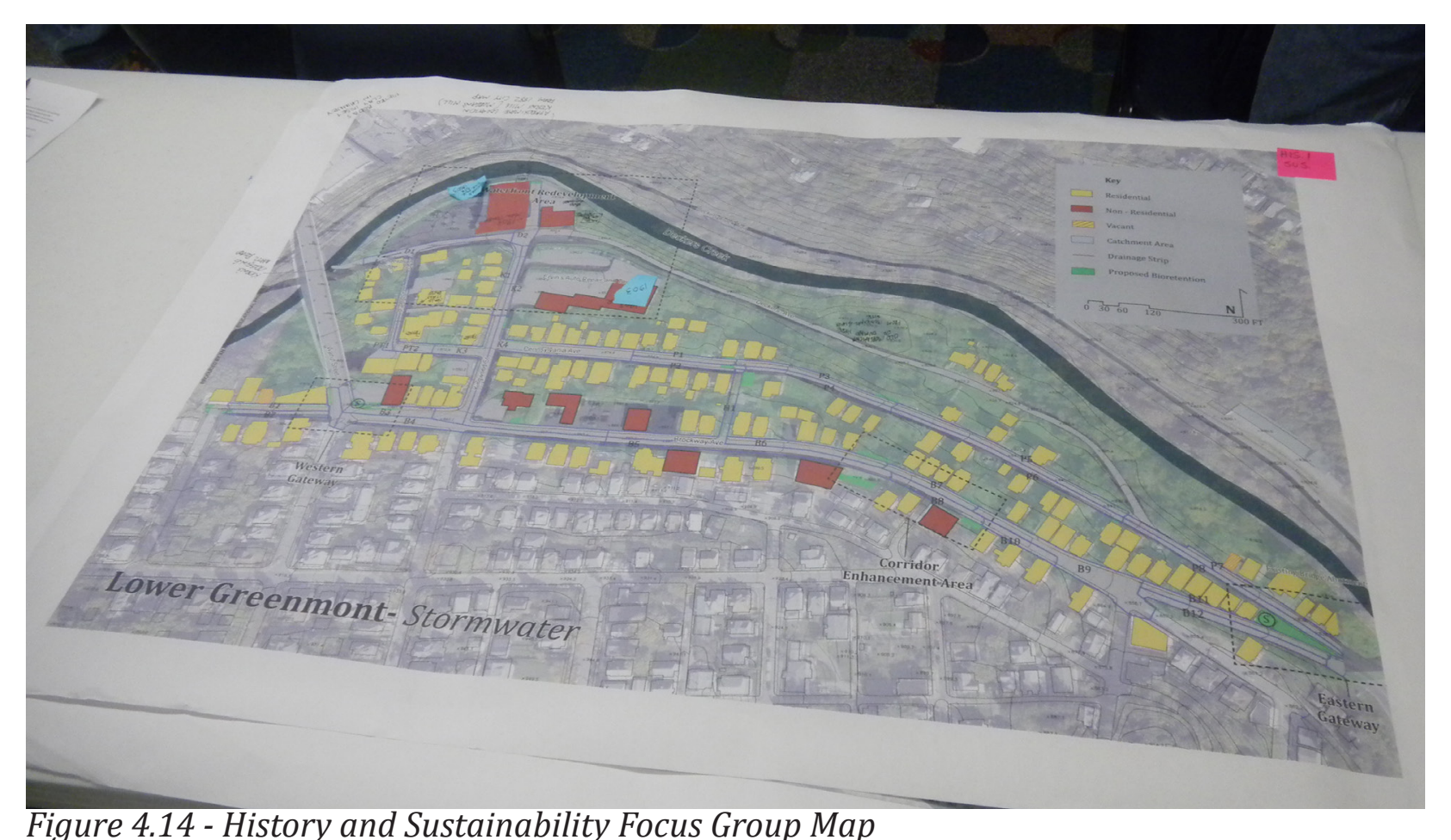

Fure $4.14-$ History and Sustainability Focus Group Map

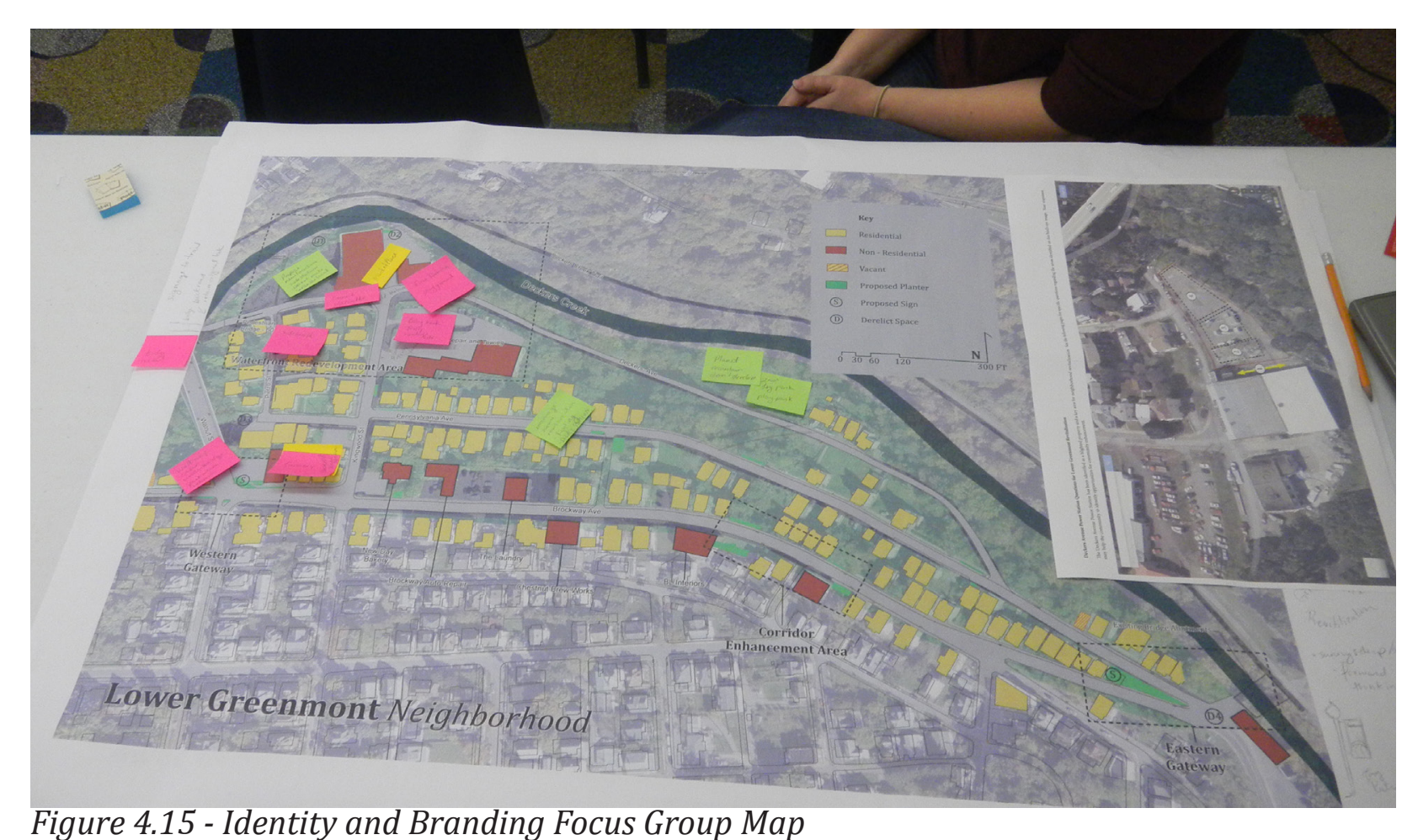

Figure 4.15 - Identity and Branding Focus Group Map 
dentify significant neighborhood spaces and transportation routes, and the asset and issues related to them.

Identify strategies for the enhancement of the identified neighborhood routes.

Discussion Synopsis

This group envisioned the Deckers

Creek riparian corridor as an 'oasis in an

urban environment', with recreational

improvements along the stream and

edestrian, aesthetic, and comm and

inprovements throughout. The group

concluded that increasing the use

of outdoor spaces would increase eighborhood safety.

The group suggested that Deckers Avenue serve as a trail, with an additional pedestrian bridge over the creek near the intersection of ennsylvania Ave and Brockway Ave. To urther improve recreational access, the group suggested a pedestrian connection from Pennsylvania Ave to Deckers Ave through city owned property.

The group identified Brockway Avenue commercial corridor enhancement as the starting point for neighborhood revitalization, suggesting aesthetic enhancements such as hanging baskets, and pedestrian safety improvements such as crosswalks. The group also identified several locations for needed pedestrian improvements and areas where garbage bins take up too much pace. 


\section{History and Sustainability Focus Group Notes}

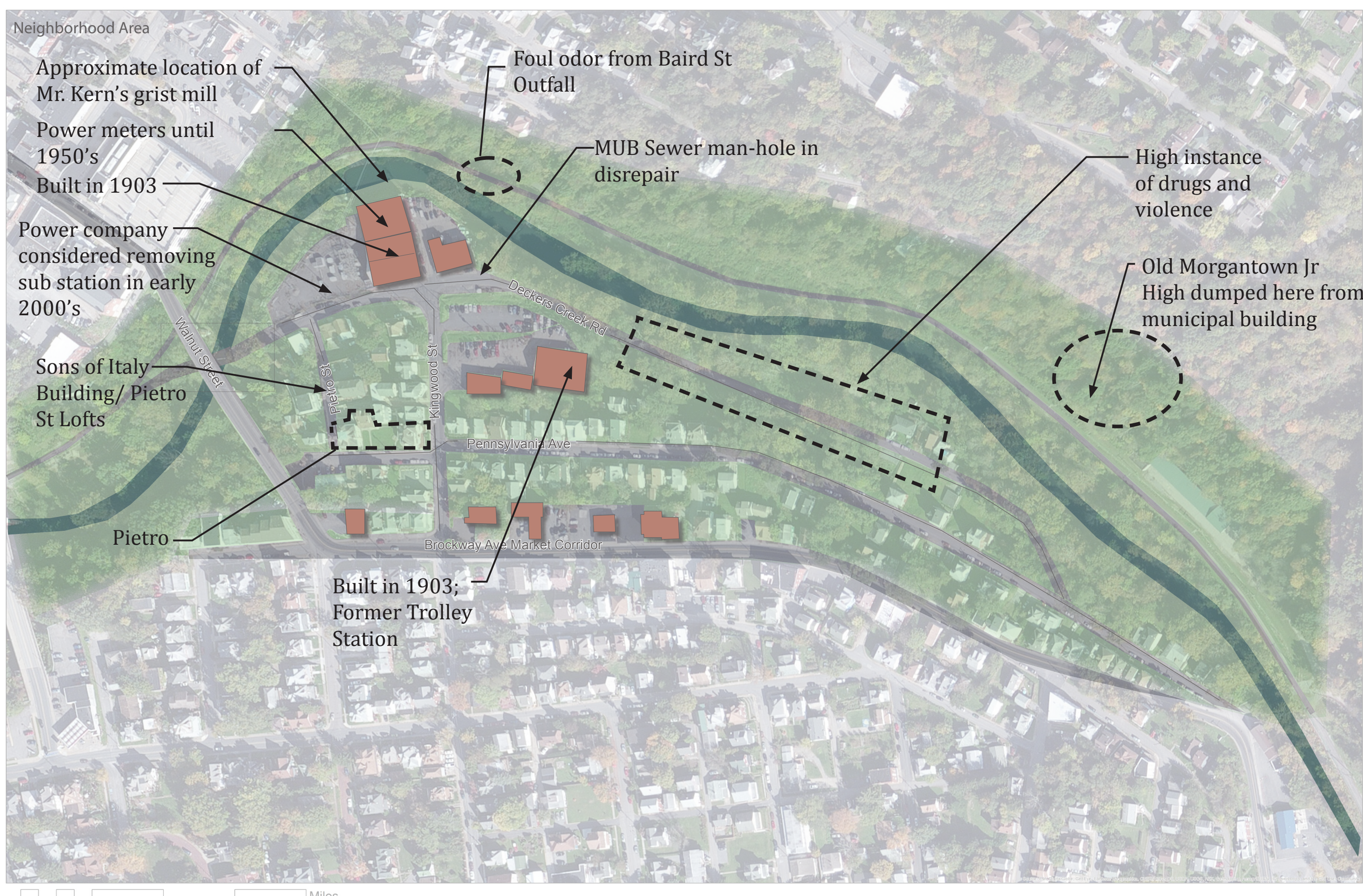

Figure 4.17 - History and Sustainability Focus Group Discussion Overview causing redevelopment planning
The identified CSO pipe is the Baird Street Outlet. efforts avoid connecting site usees with the is the Baird Street Outlet.

Participants

-Local historian/ neighborhood association president

-Neighborhood resident/ historian -Industrial property owner

-Sustainable development specialist

\section{Prompts}

Identify key historic structures and materials worth preserving and sustainability issues and needs.

Identify materials to preserve and/or reuse, new materials that may enhance historic framework and opportunities for sustainable redevelopment.

\section{Discussion Synopsis}

As the other groups busily added post-it notes to the provided maps this group was less interested in recording discussion. This group engaged in meaningful discussion related to industrial property reuse planning that did not necessarily relate to the prompted tasks.

The group identified the installment of the new bridge as an opportunity for broader improvement including pedestrian safety enhancements, private property maintenance, etc.

The property owner discussed two significant issues related to stormwater infrastructure: a strong odor from a combined sewage overflow(CSO) pipe on the opposite side of Deckers Creek and a sunken in man-hole between the form in manBaly's Auto and the creek. Th mitigating the smell and negative perceptions associated with it. 


\section{Identity and Branding Focus Group Notes}

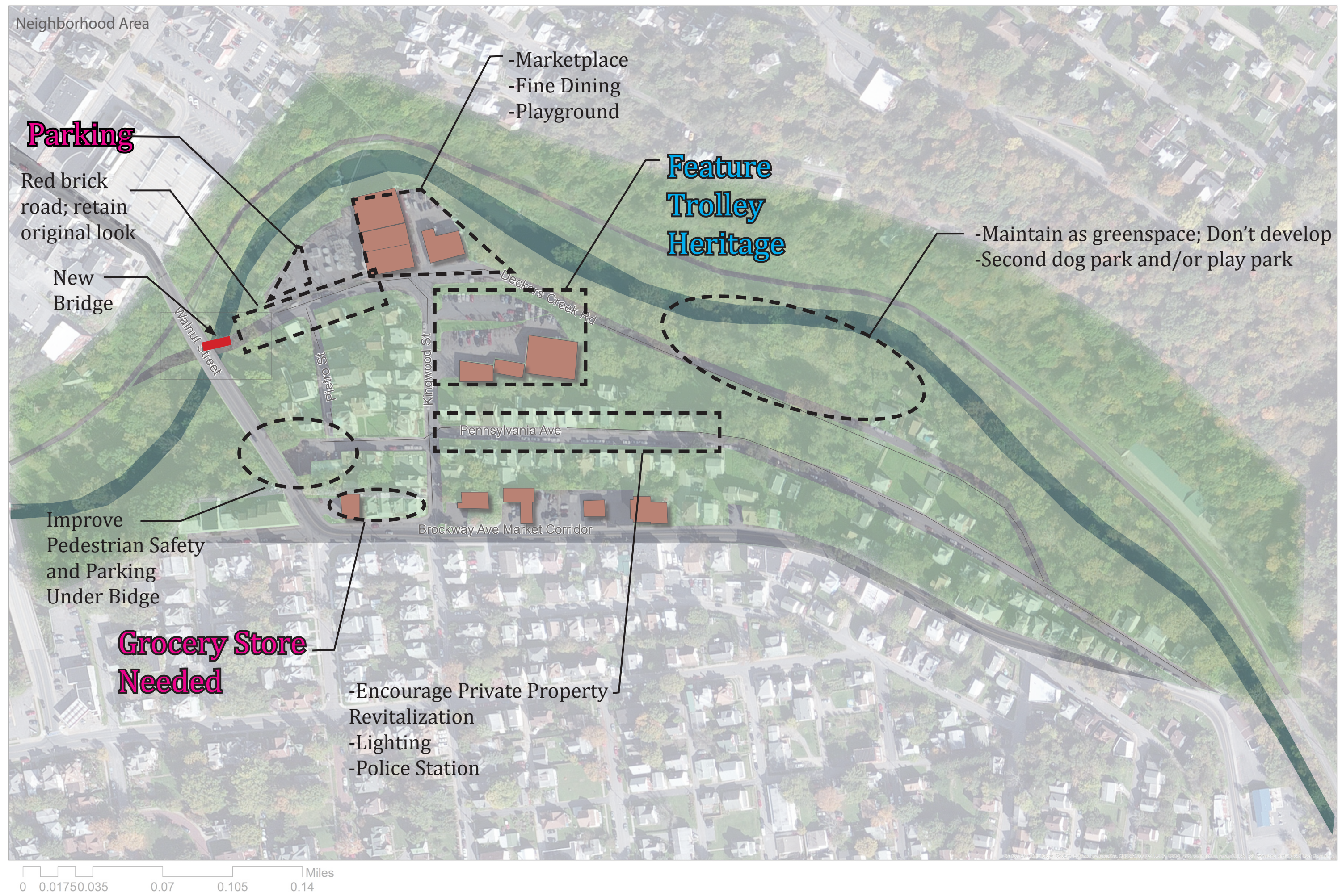

Participants

-Environmental Scientist/ Working on Area-Wide Brownfields Assessment

-Architect/ Working on Industrial Property Reuse -Neighborhood Resident/ Graphic Artist

-Area Resident/Human Dimensions and Natural Resources Student

\section{Prompts}

Identify commercial needs and locations where they may be provided.

Design a brand for the redeveloped waterfront and ideal locations, orientations, and materials for signage.

\section{Discussion Synopsis}

This group suggested a grocery store on Brockway Avenue, a nice restaurant and community marketplace in the industrial redevelopment area, and a dog park and/or playground in the undeveloped lots along Deckers Creek. The group also suggested minimal development along the waterfront to benefit the plonet. This aloup al waterfront to benefit the propment to feature the history of the former trolly sty to feature the history of he forner trolly station. Pedestrian access and safety enhancements were Wa susted along Deckers Avene, under the Walnut Street bridge, and along Pennsylvania 


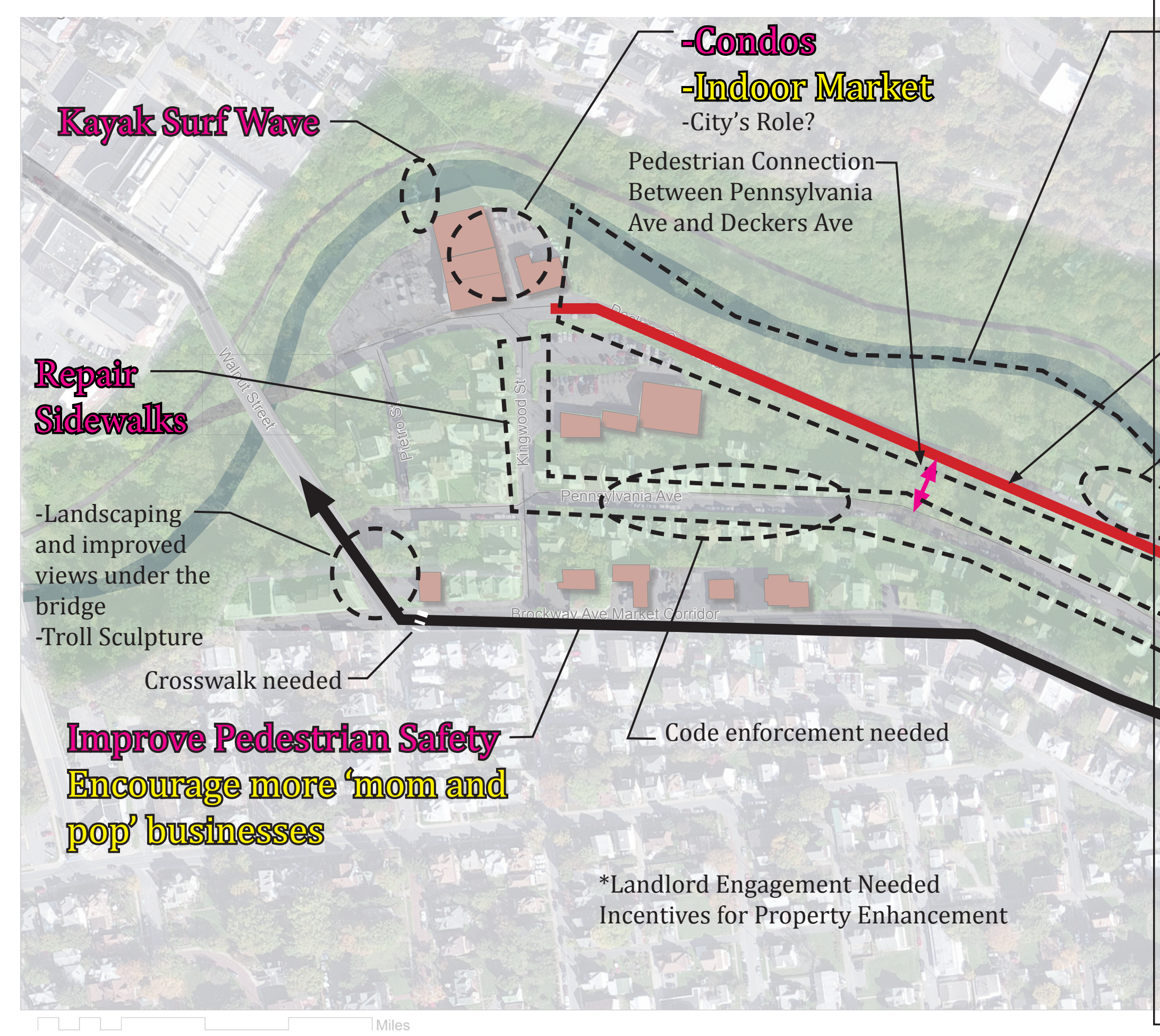

$\prod _ { 0 } \longdiv { 0 }$

Figure 4.19 - Recreation and Quality of Life Focus Group Discussion Overview

\section{- Rivomerian Restoration}

- Remove pipes from stream

-Remove invasive species

-Plant native species

\section{- Recreation Thinhancernernots}

-Benches

- Lighting

-Improved Views

Consider Shutting Down for Cars; Pedestrian Only

Consider Removing Homes from Waterfront

Recreational Parking

\section{Mixed 'livable'} residential

Pedestrian bridge for a trail loop with Deckers Creek

\section{loop with Deckers Creek}

\section{Participants}

Parks and Recreation Specialist/ Former River Town Program Facilitator

Landscape Designer with interest in waterway recreation

Resident/ Background in Land Use Management nd Forest Ecology/ Active in FODC and WV Land Trust

-Resident/ Water Quality Manager/ Kayaks Lower Deckers Creek

\section{Prompts}

dentify the neighborhoods recreational, visual, and ecological assets and issues.

dentify opportunities for visual and recreational stream access and park amenities.

Discussion Synopsis

This group focused on big picture opportunities or community building, wildlife restoration, and commercial improvements through aesthetic and ecreational enhancements. The group suggested estoring and improving the appearance of the reek, providing stronger pedestrian connections rom the commercial corridor and the high schoo rom the creek and discouraging heavy truck traffic to on and use of recreational spaces in order to provide more areas for friendly, neighbor interactions, mprove area ecology, and increase pedestria ransportation to commercial areas.

To restore the creek, the group suggested the management of invasive species and the plantin of native species, in phases, as well as removing garbage from the stream. The group proposed mproving Deckers Avenue for recreation by closing the street to vehicles and removing the esidential structures between Pennsylvania Avenue and the industrial waterfront.

To improve the commercial corridor, the group suggested the consideration of re-routing of heavy truck traffic through the city, the highlighting of existing local businesses, and the encouraging of more 'mom and pop' businesses along the corridor. The group identified community building opportunities through connecting key neighborhood locations with attractive, highly utilized, and opportunities through connecting key neighborhood locations with attractive, highly utilized, and safe recreational paths. The group suggested that these improvements would increase resident
sense of neighborhood pride and ownership, encouraging residents to take better care of it. 


\section{Chapter 5 - Inspiration}

While incorporating the ideas and interests of the meeting participants and local stakeholder groups, case studies from several existing establishments were used to inspire the design. Some of these include the Seneca Center in Morgantown; Evergreen Brickworks in Toronto, ON; and the community Whitewater Park in Durango, CO.

\section{Seneca Center}

The Seneca Center is a local business marketplace and museum located in a historic glass factory on the Monongahela River. The facility features a red water tower and brick furnace that preserve industrial heritage and contribute to the city's identity. The center features a trailside access and houses restaurants, a bike shop, and a running shop, among other businesses. These uses make the Seneca Center an attractive destination for trail users. The redevelopment of the industrial waterfront in Lower Greenmont into a trail destination that similarly, preserves the site's historic industrial fabric, will contribute to a network of waterfront attractions throughout the city.

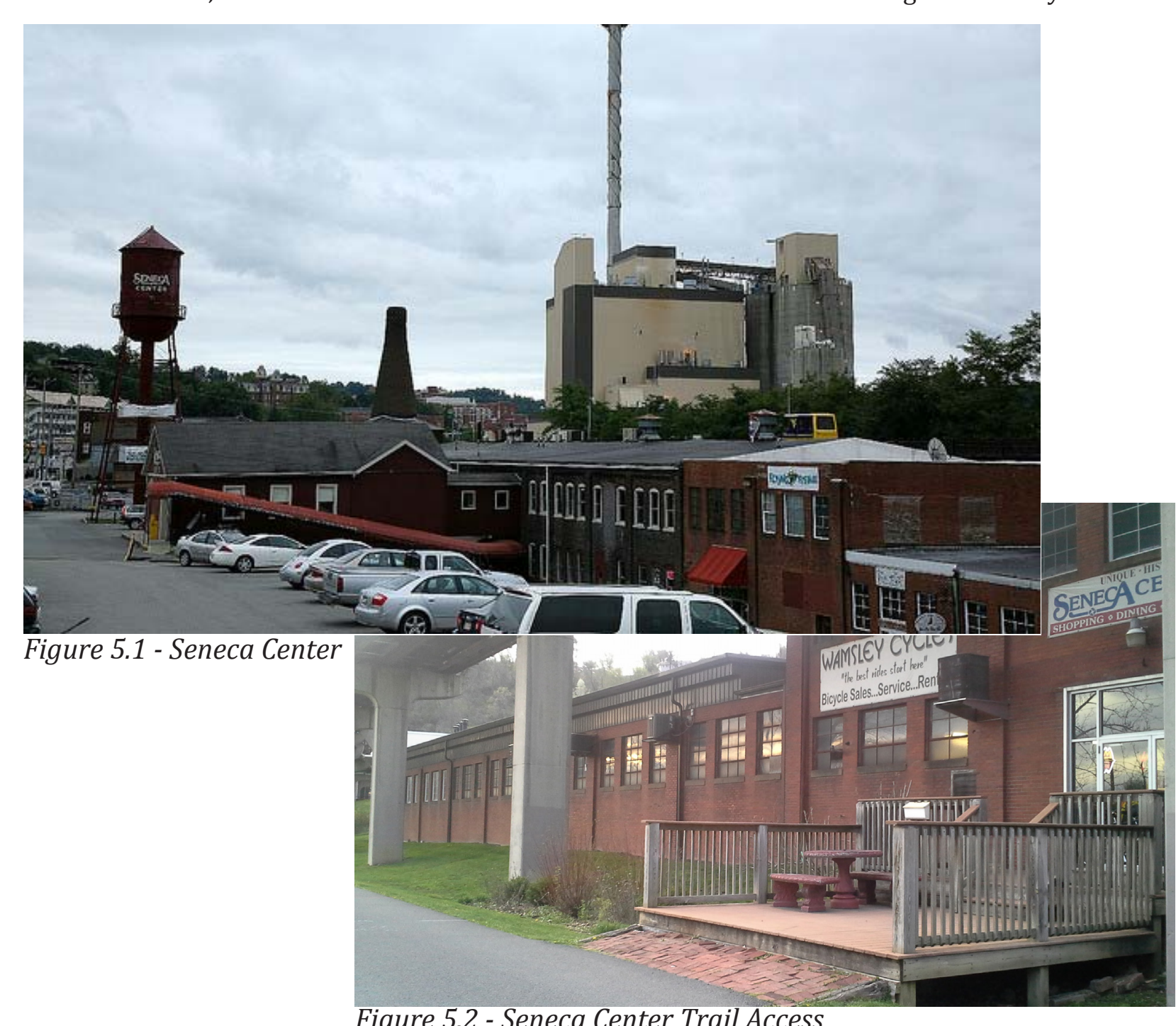

Figure 5.2 - Seneca Center Trail Access
Durango, Colorado Whitewater Park

FODC's 2020 Vision to have Deckers Creek swimmable by the year 2020, opens a multitude of local recreational and economic growth opportunities. Long term plans to feature a swimmable Deckers Creek will maintain the momentum of stream restoration efforts and result in community and commercial development being intertwined with the waterway. Imagining a restored waterway, waterfront redevelopment efforts may parallel those in areas that utilize the full recreational benefits that waterways provide, like the whitewater park being installed in the City of Durango, CO. The Durango Animas River Corridor Management Plan includes public transit for river tubers and attractive river accesses lined with natural boulders and native plantings. The corridor management plan identified the natural water feature known as Smelter Rapid as a primary improvement area. A whitewater park surrounding the rapid was designed in 2011 and installed in 2014. The park is now a central community feature that attracts new residents and tourists to the area. The park features natural areas, improved in-stream water features, riverside viewing areas, and connections to the area's trail network.

A similar corridor management plan for Lower Deckers Creek would likely identify the Waterfront Redevelopment Area as a primary improvement area because of the recreational opportunities Revided by the water featire and the nateen previde by therfront Redevelopment Plan draws inspiration from the Durango Whitewater Park by highlighting the local waterways natural features to contibute to enhanced trai riews and accesses. The installed desig will result in area visitors and residents identifying Deckers Creek as a key area attractions.
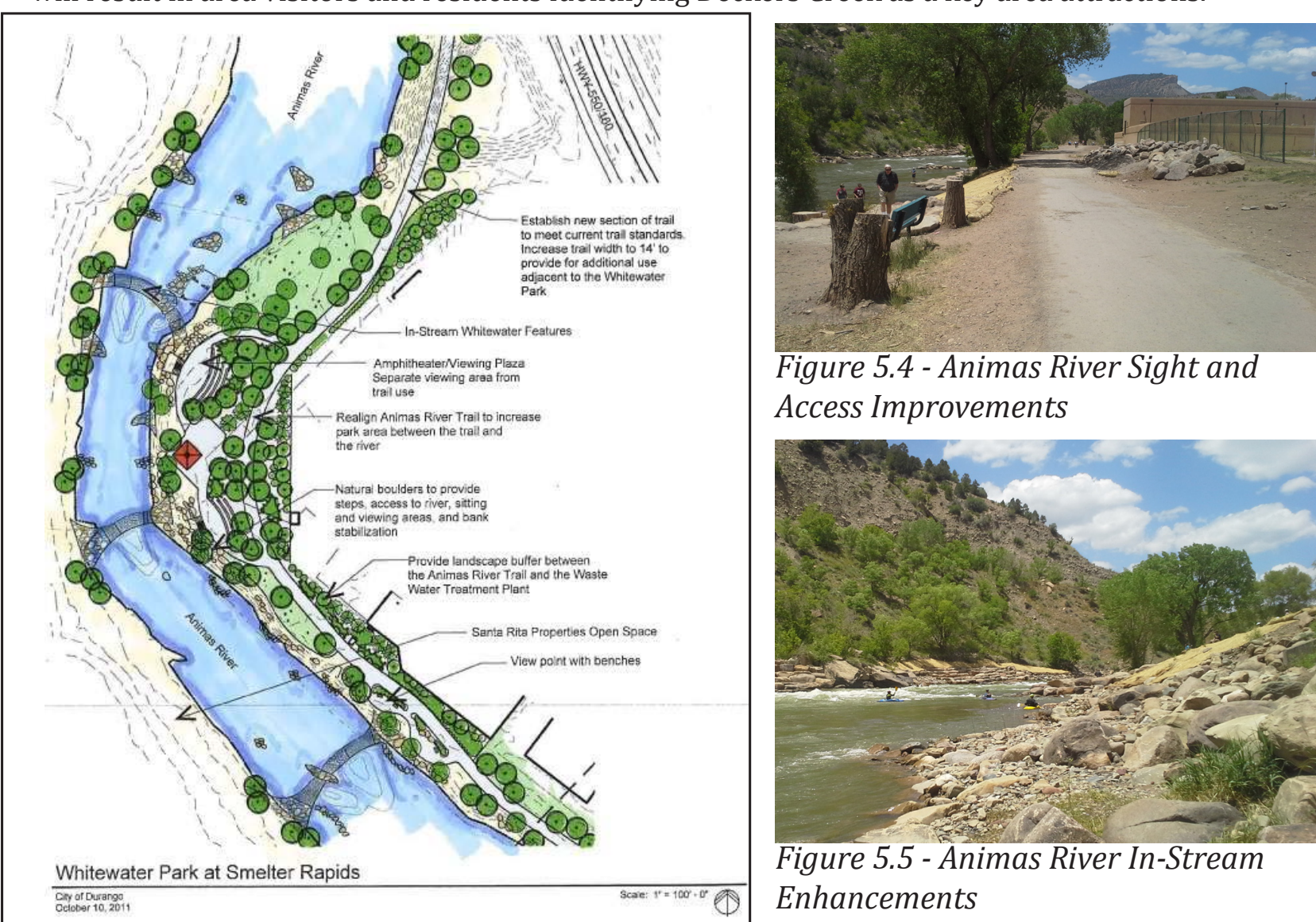

Figure 5.4 - Animas River Sight and Access Improvements

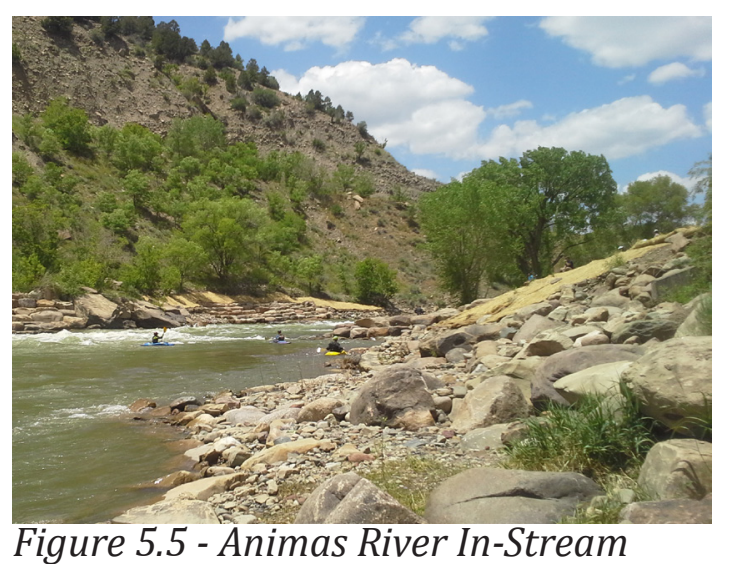
Enhancements

Figure 5.3 - City of Durango Primary Improvement Alrea Plan 


\section{Evergreen Brick Works}

Evergreen Brick Works is a multi-use community environmental center in Toronto, Ontario, located on a former brick manufacturing industrial complex. After the Don Valley Brick Works property sat vacant for several years, inviting raves, graffiti artists, etc., the property was redeveloped into parks, gardens, shops, and offices. The lengthy site redevelopment process involved extensive community engagement, planning and compromise. The site today is a living testament of the value of partnerships between cities and authorities (Holcim, 2012). The redevelopment of the Industrial Waterfront Area can draw inspiration from Evergreen Brick Works by involving a similar level of community engagement to identify successful site uses and achieve rich site character through preservation and design.

Designers adapted existing infrastructure and character elements at the Don Valley Brick Works site and repurposed the site to serve as a community center, business complex, and event space. The innovative design is, surprisingly, passive in terms of preserving elements such as graffiti. industrial equipment, etc., showcasing these elements as artful pieces of site history. In a addition to preserving these interesting pieces the design includes green infrastructure to treat stormwater and education col con issues through art and site includes an artful wateres conservation and filtration systems within the site's

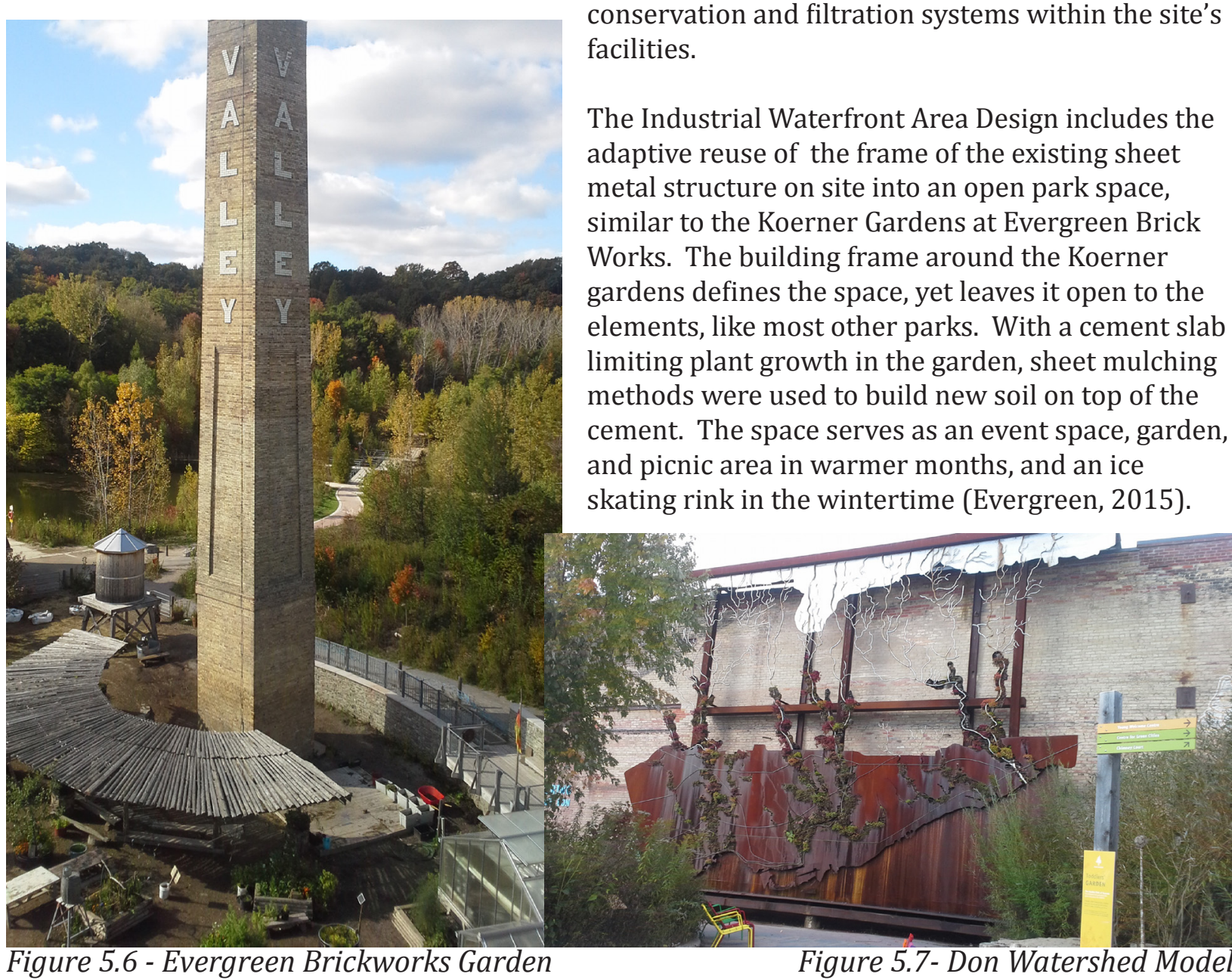

Figure 5.8 - Evergreen Brick Works Welcome Center

Remnants of the site's industrial history add depth and interest to the site character.

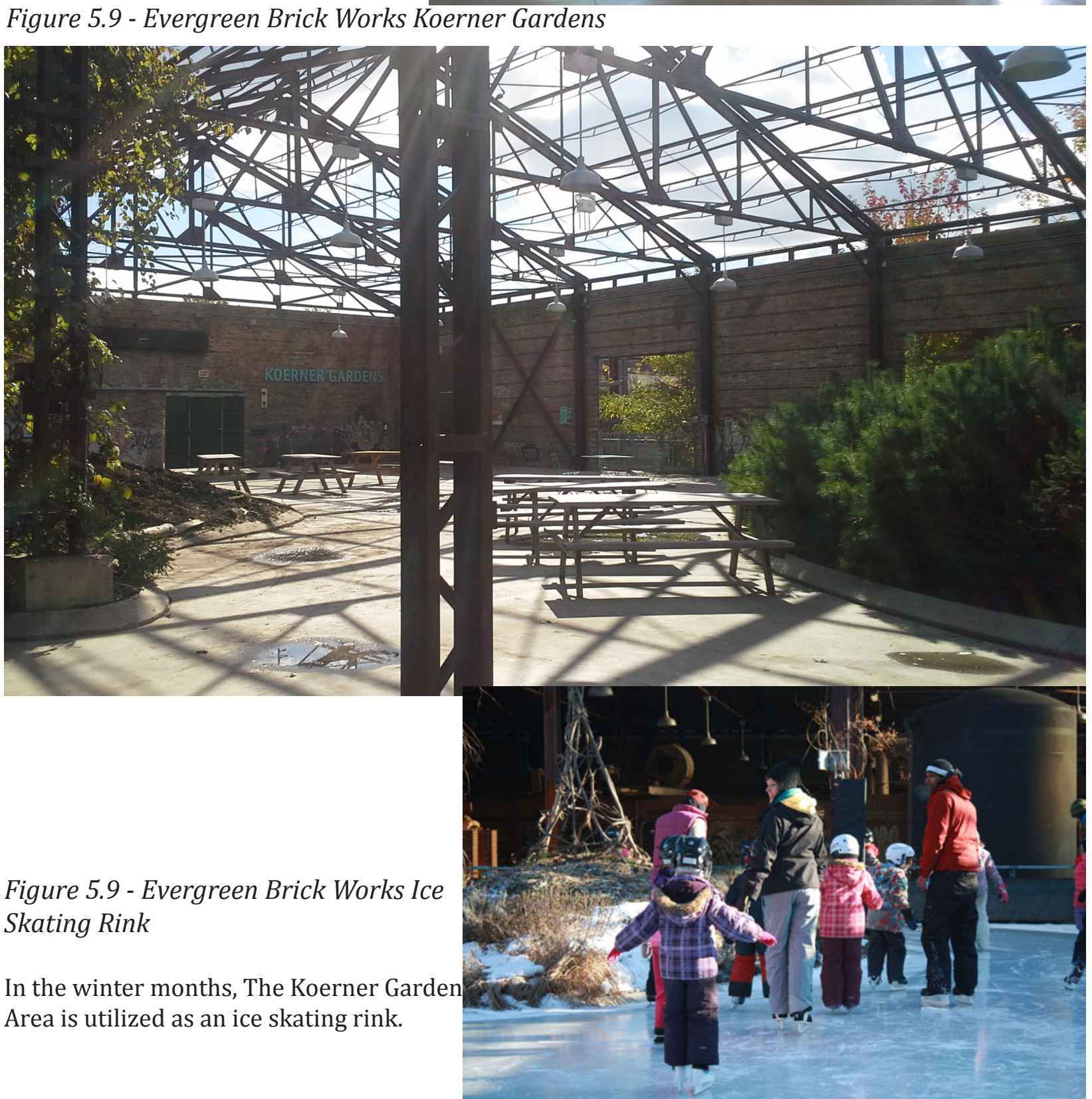




\section{Chapter 6 Neighborhood Design}

Master Plan
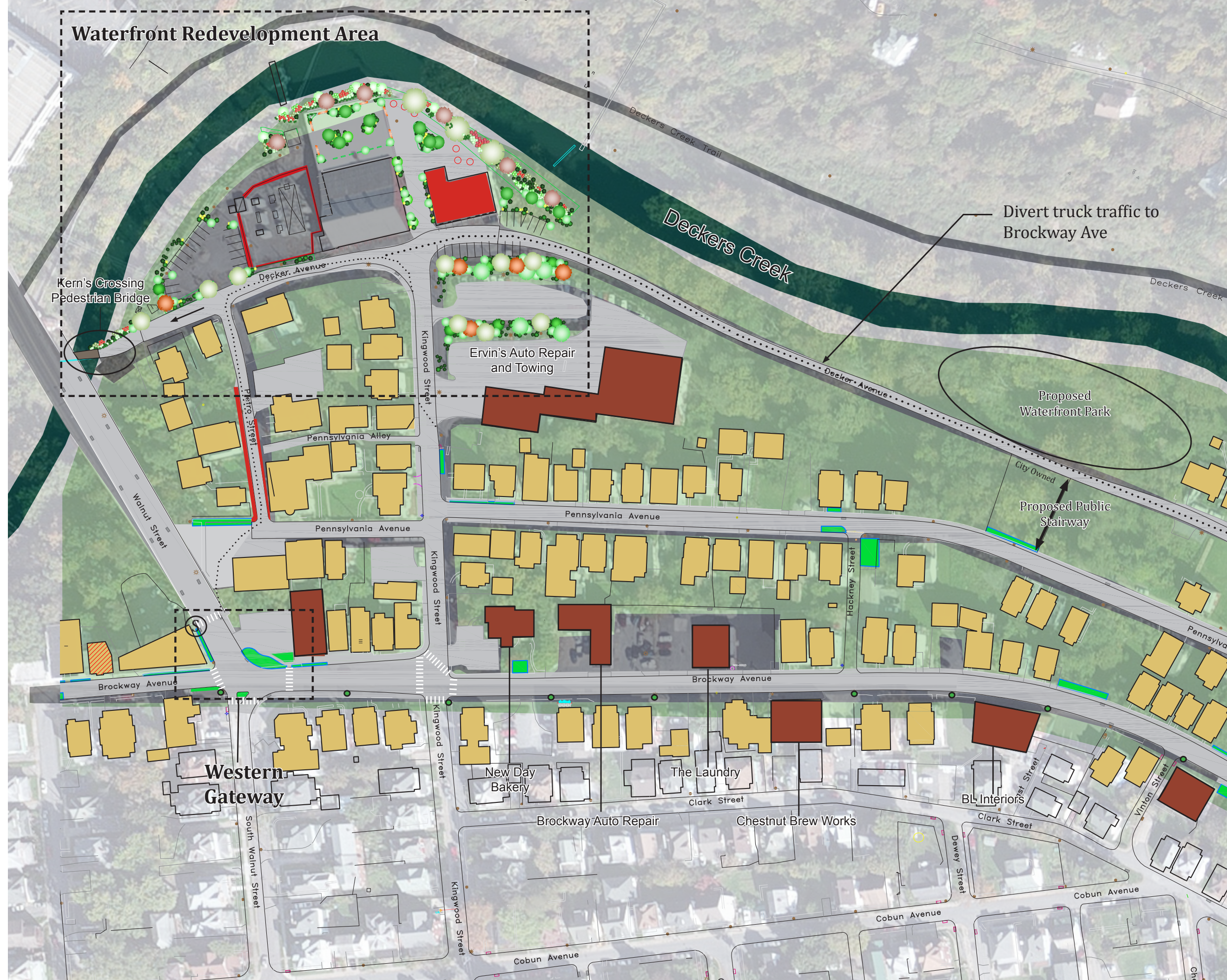

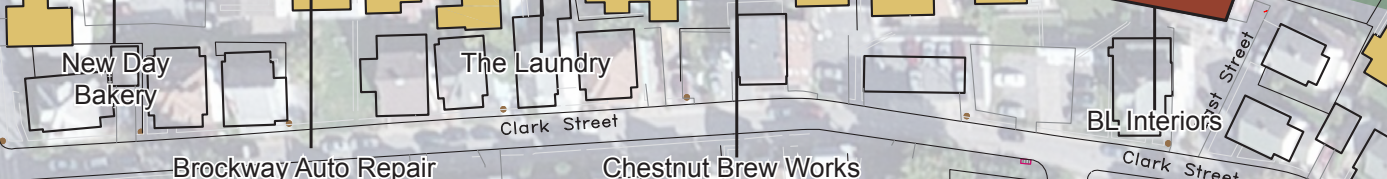
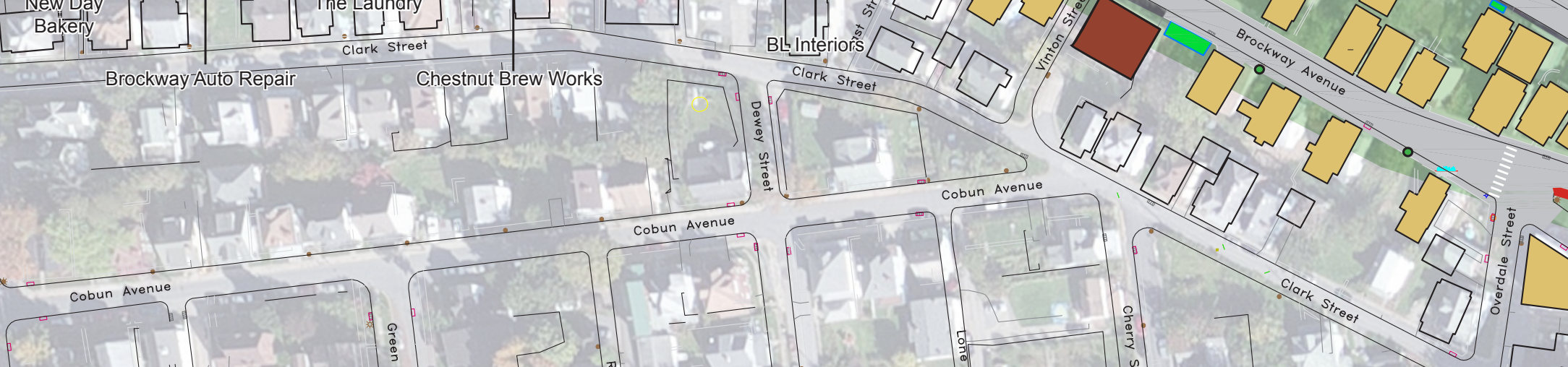

58 Lower Greenmont Revitalization Master Plan

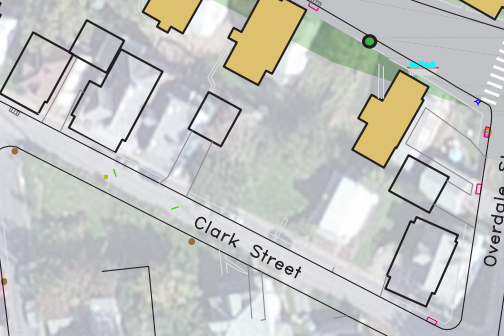

\section{Key}

$\square$ Residential

Non - Residential

叉D Vacant

Proposed Planter

Proposed BioCell

(S) Proposed Sign

- $\quad$ Proposed Flag/Hanging Basket

॥ाшиแ Proposed Cross-walk

...... Proposed Painted Footpath

Proposed Sedum Mix

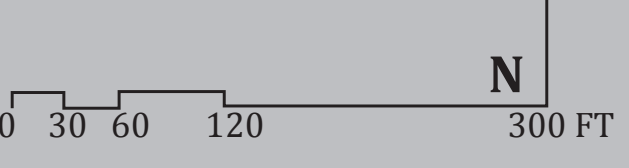

Figure 6.1 - Lower Greenmont Revitalization Master Plan 


\section{Signage}

This neighborhood master plan includes signage, greenery, pedestrian crosswalks and stormwater improvements along the Brockway Avenue Corridor as well as detailed designs of the eastern and western community gateways and the waterfront redevelopment area. Proposed "Welcome to Greenmont" signs, flags, and hanging baskets will provide a sense of place identity for motorists passing through. Collectively, these elements will catch the eye of motorists, likely causing them to reduce their speed, improving neighborhood pedestrian safety.

WELCOME TO
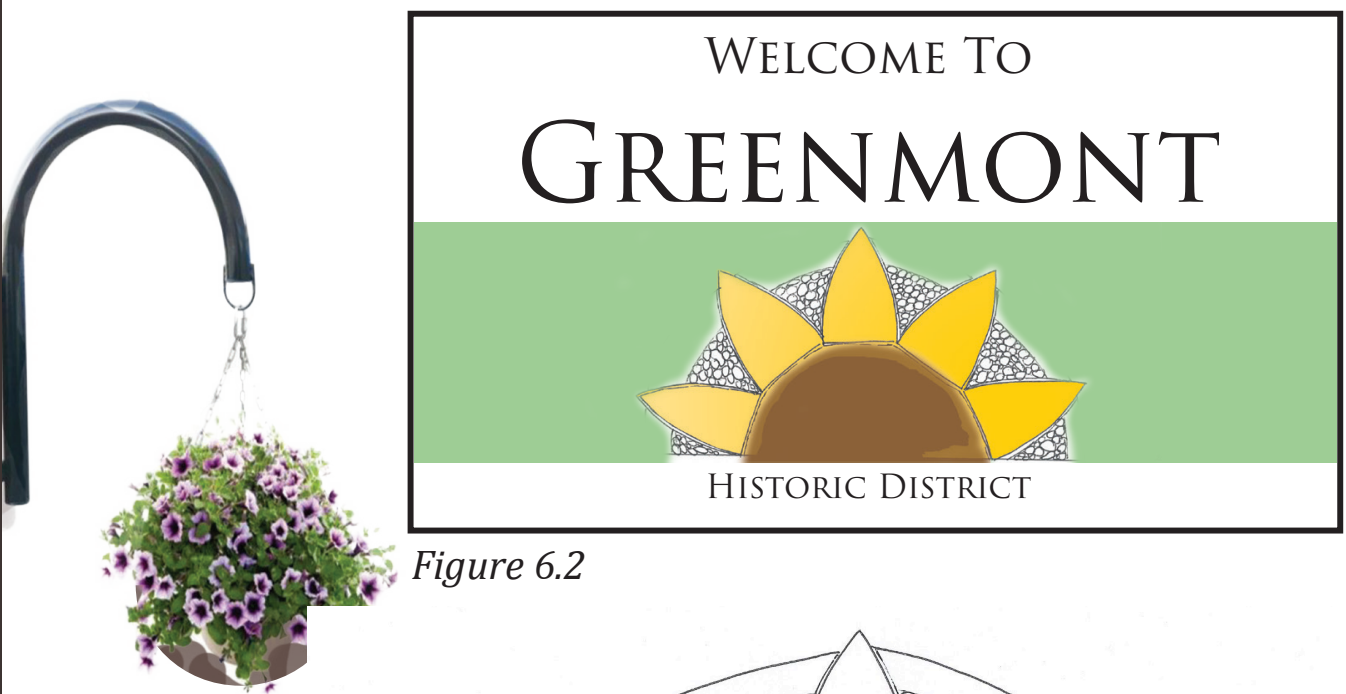

Figure 6.2

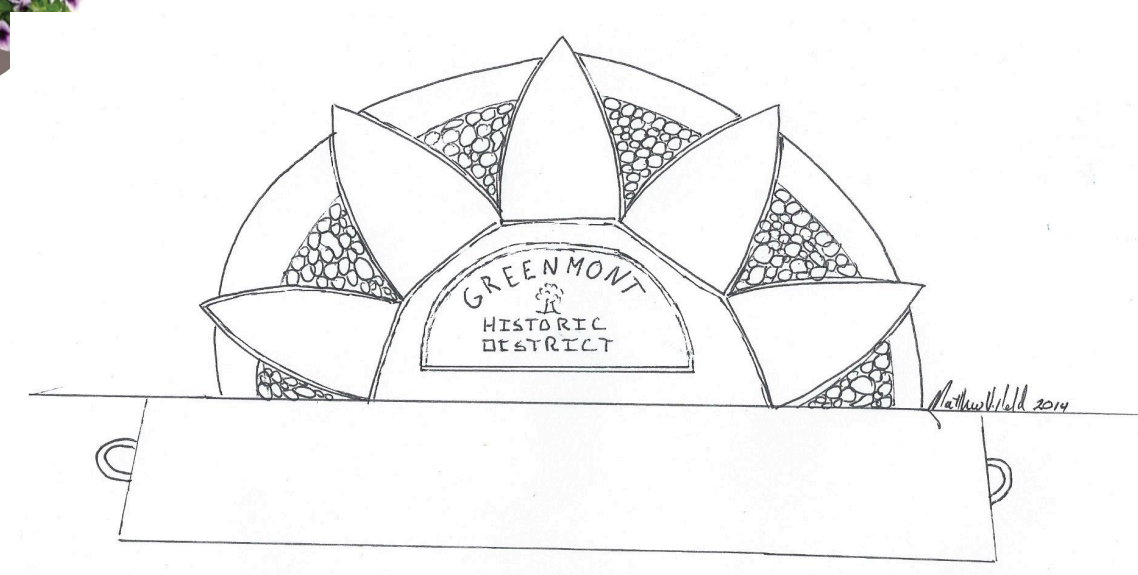

Figure 6.3 - Arch Street Sign Design

Thoney Pietro incorporated the top half of a 10-point-star as a signature element in his constructions. Figure 6.3 is a vigniette of a sign that the GNA is working to install on Arch Street (in another area of Greenmont). The Arch Street sign will include stone and metalwork, to be constructed by a local artist. The logos proposed for the signs and flags for the eastern and wester community gateways and the Brockway Avenue corridor incorporate the historic logo into one that may be easily printed and installed by a local sign histoic log in from the a company. Aside from the eastern gateway sign, all of the proposed locations are

\section{Pedestrian Improvements}

Proposed bioretention cells will insulate pedestrians from vehicular traffic and further enhance neighborhood aesthetics, in addition to providing environmental benefits. Proposed crosswalks will slow vehicular traffic through the neighborhood and improve pedestrian safety.

Painted footpaths will guide pedestrian traffic to continue paths where sidewalks end and/or sidewalks are unneeded, allowing low-traffic roadways to serve pedestrians as well as vehicles.

\section{Recreational Enhancements}

Closing Deckers Ave to heavy trucks, will make the low-traffic volume road more appealing to pedestrians. The proposed Waterfront Park will provide a destination along this recreational path. The proposed public stairway will connect pedestrians from other areas of the neighborhood to the park. Trail users on this path may continue to the proposed second pedestrian bridge to access Deckers Creek. The second bridge will add a key access at a secluded section of trail. With 2 pedestrian bridges, neighborhood residents will have access to a 1-mile trail loop that connects to the larger trail network.

\section{Sedum}

A sedum mix will increase permeability and aesthetics in proposed areas in the waterfront redevelopment area and on underutilized sidewalks. Trays including growing medium and sedum plants are proposed to be installed along the fence in the Deckers Avenue Power Station and on the rooftop of the former Bailey's Auto facility. ped pedestrians because the sths the road. Furthermore, the sidewalk on the south side of Brockway Avenue is uncontinuous, unsafe, and overgrown. The proposed

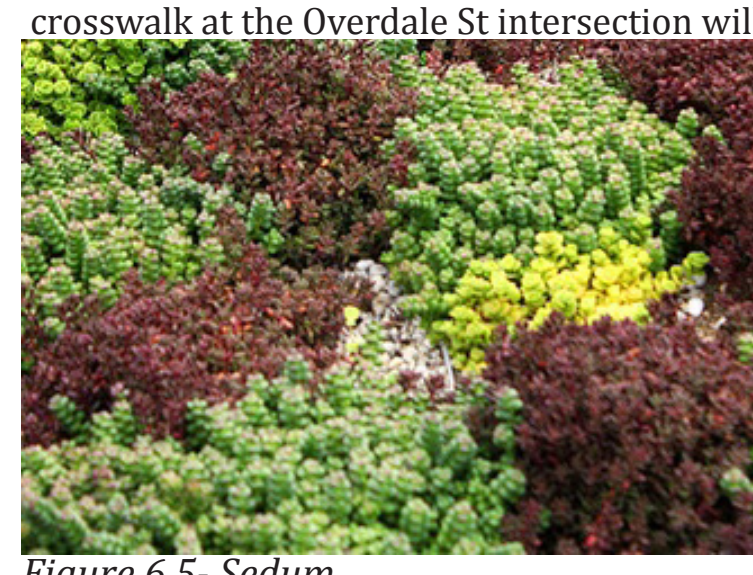
de pedestrians onto the north side of Brockway Ave. Planting the underutilized section of sidewalk with the sedum mix will enhance appearance and permeability. The resilient plant can withstand light human and vehicular traffic.

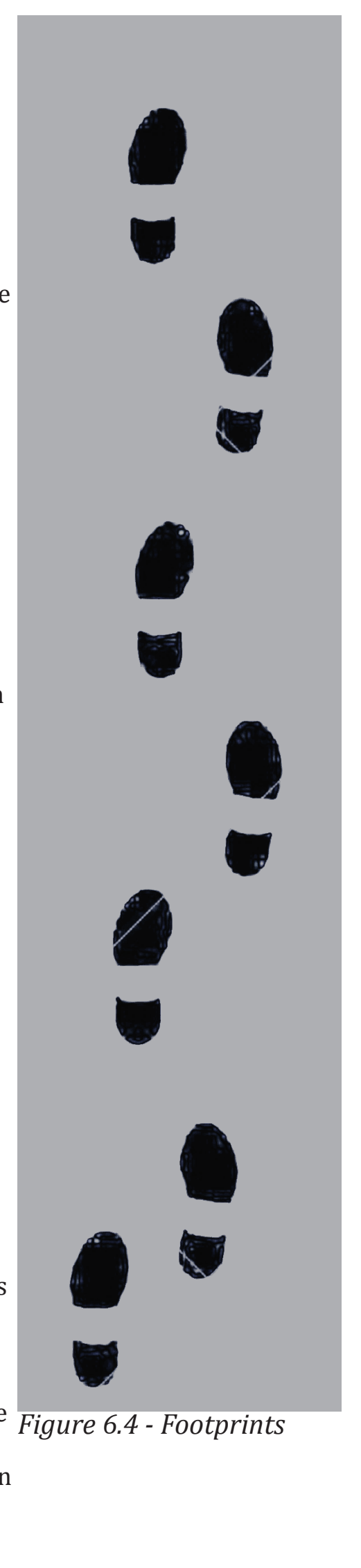




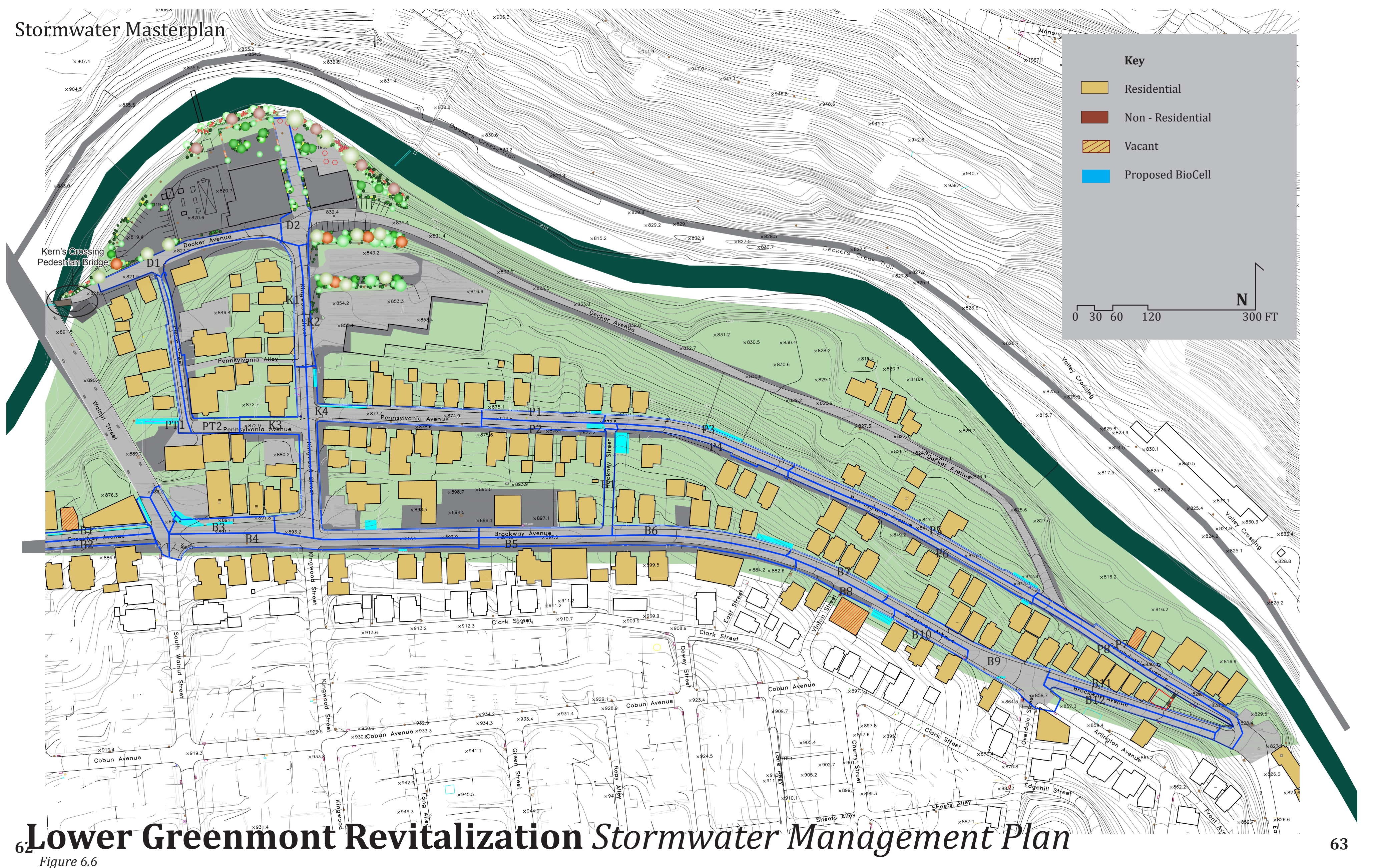




\section{Lower Greenmont Revitalization Stormwater Notes}

This draft stormwater management plan aims capture stormwater from sidewalks and streets in proposed bioretention cells above existing catchment basins. Once filled, the cells will overflow into the existing stormwater network. Typical details can be found on pages 7-9 (SW 310-312) of the City of Portland reference document.

The stormwater spreadsheet includes catchment areas (not including private properties), drainage strips, and other stormwater calculations. The bioretention areas proposed in the plan do not correspond to the calculations suggested in the spreadsheet. The proposed cells were sized based on space availability and grading limitations.

\section{Eastern Gateway}

Below the proposed sign at the Eastern Gateway, the footprint of a home that is proposed to be demolished is shown. I believe that the City of Morgantown may be gaining control of this property, and know that the Griberno pred the property to the east is not listed on the local parcel map, and I believe, is also under the control of .

Garbage, paired with excessive runoff, in this area is a significant issue. Aside from deterring from community aesthetics and pride, debris pollution clogs storm drains, contributing to flooding. During the flood event on the morning of Wednesday, March 4th, I met, Justin Harpe, a residen in the home adjacent to the catchment basin in area P7. His home was flooding at the time, and he mentioned that flooding is a recurring issue that he has to report to Morgantown Utility Board frequently. Shortly after that, a MUB utility vehicle and crew arrived on the scene, and removed garbage from the drain to relieve the flooding.

A tiered bioretention installment throughout the area within the Eastern Gateway, shown in green, would be a significant project. However, paired with the proposed "Greenmont Historic District" signage and attractive plantings, the project would provide significant enhancement to the neighborhood which may increase neighborhood pride, which may help mitigate the litter issue.

H1 The bioretention area proposed below catchment area $\mathrm{H} 1$ is on private property.

P3 The proposed bioretention cells below catchment area P3 is located on parcels owned by the City of Morgantown.

Additional Notes - Deckers Ave and Pietro St are still being analyzed for bioretention opportunities
Bio-retention areas

Bio-retention areas can capture runoff from impervious surfaces, preventing issues related to storm water influx, Storm water relate to stor water and other bio-retention a, ras garly infiltrates into the ground prown enfiltrates into the gound, promoting groundwater recharge. Furthermore, bioretention areas are typically planted with native plant species that filter water and provide wildlife habitat. The installment of bio-retention areas throughout the developed areas surrounding rivers and streams will promote waterway

health by filtering storm water and slowing its path to the creek. 


\section{Waterfront Redevelopment Area}

At the meeting conclusion, the property owner expressed plans to develop a 6-7 story mixed use structure that would retain the facade of the historic power house to replace the three waterfront buildings. He expressed that discussions to date have been for the structure to include commercial and parking on the ground floor, a green roof, swipe card vehicular access, and, potentially, a bridge connecting the property to downtown. This model roughly demonstrates the size and form of

the proposed strcture, as described in the meeting, and the impacts that the redevelopment may have on the landscape. A tall structure adjacent to the creek will have a significant impact on the waterfront, effecting trail users, residents, and the local ecology. The thoughtful considerations of these impacts may influence the design of the structure so that the redevelopment is perceived as avorable by the surrounding neighborhood.

\section{Sustainability}

Dense, urban infill is a standard model for green development. Furthermore, the inclusion of parking within proposed developments is also an efficient model (Farr, 2008). Additiona commercial spaces, as proposed on the structures ground floor will integrate needed commercia facilites into the residential industrial waterfront that is not currently benefitting the community.

\section{Impacts on Trail}

The property's location on the inside of a bend in the creek, increases the visibility of the site from the trail and the length of waterfront along the property. The appearance of the "back side" of the structure will have a significant impact on trail aesthetics. Furthermore, the section of rail-trail behind the site has been identified as an area of safety concern due to seclusion at public meetings held by the City. Site redevelopment which incorporates appealing views from the trail and draws people to the Lower Greenmont waterfront will improve trail views and increase local eyes on the secluded section of trail, improving safety. Conversely, development which faces away from the waterfront or does not include favorable views to the trail may contribute to negative local perceptions of the development and the affected section of rail-trail becoming even more secluded, and, therefore, more of a safety concern.

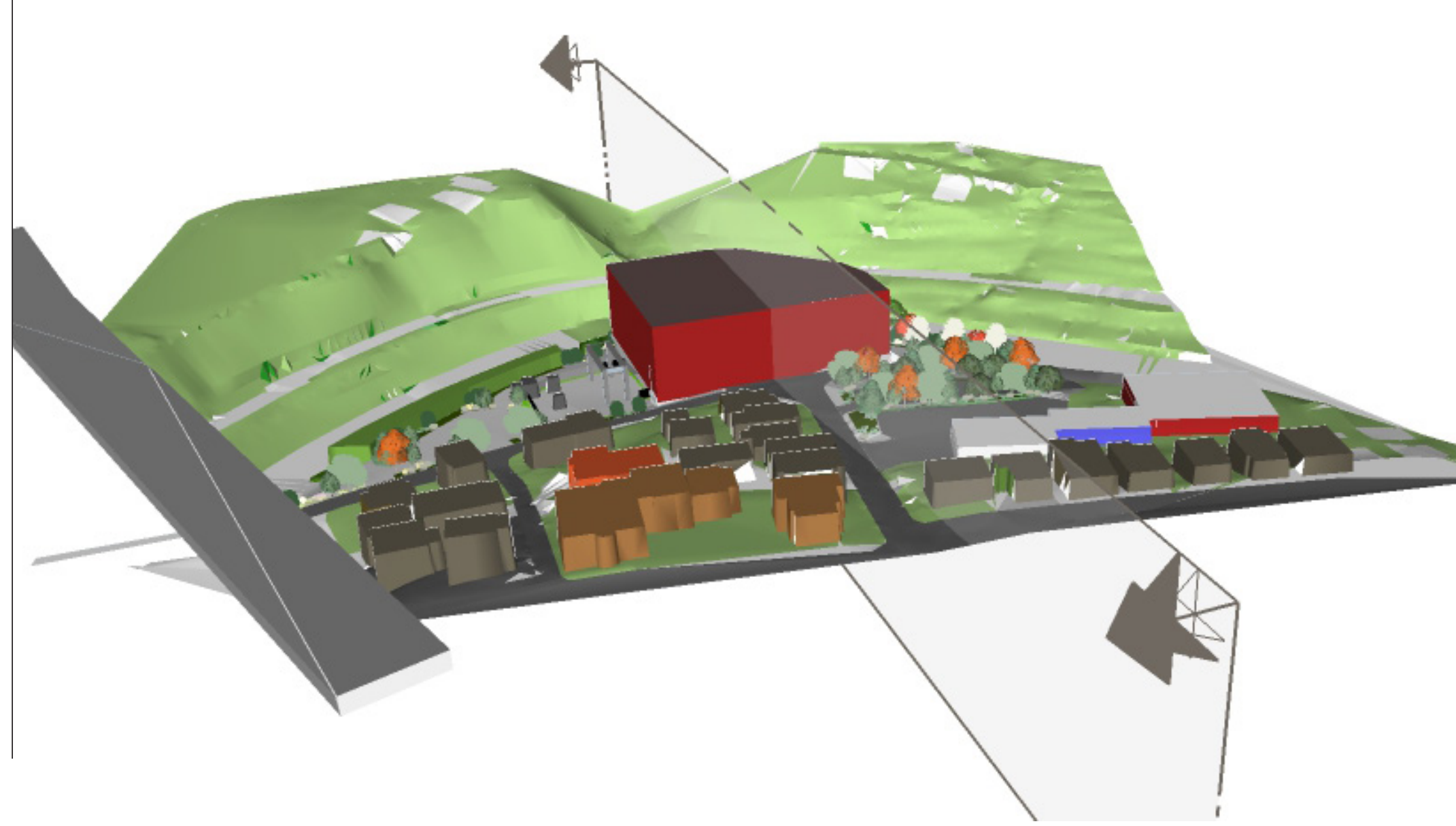

Abrupt height change-

wildlife barrier

Shadows cast to

the north- inhibit

egetation growth 


\section{Impacts on Ecology}

A tall structure on the site will cast a shadow on the riparian buffer area to the north, inhibiting the establishment of native plantings along the waterway. This may lead to further bank erosion Furthermore, the $50^{\prime}+$ abrupt height change against the riparian edge will serve as a barrier for local wildlife. The proposed green roof on the structure will help mitigate the ecological costs of and integrate the structure into the local riparian ecology.

\section{Alternative Design}

The site's features and location offer much opportunity for it to serve the needs of the existing population and guide the revitalization of Lower Greenmont. The low head dam and form of the creek add much natural value to the site, and the site's existing infrastructure adds authentic site character unique to the location, that could not be easily recreated. Furthermore, the site is located at a key pedestrian and vehicular node, providing much opportunity for multimodal connections While the redevelopment plans outlined on the previous page include self-contained parking, allowing the redevelopment to not increase neighborhood parking issues, redevleopment of the site to serve primarily as a pedestrian and trail destination may improve neighborhood parking and aesthetic/recreation needs. A soft transition from the natural creek area into developed areas will transform the waterfront into a vibrant community space with improved site aesthetics, wildlife habitat, and human connections to the creek.

This alternative site design provides recreational and visual human connections to the site's key water feature, and sugests the adaptive reuse of existing structures to transform the waterfron into a rique park space that will attractral users into Lower Greent. Local offices and busing businessf wild diven layout office and/or commercial space. Like the Evergreen Brick Works redevelopment, continued community engagement will contribute to a dynamic site design that will serve as a key community center where historic materials and equipment contribute to rich site character, material interest, and heritage preservation.

Painted footprints guide pedestrian traffic
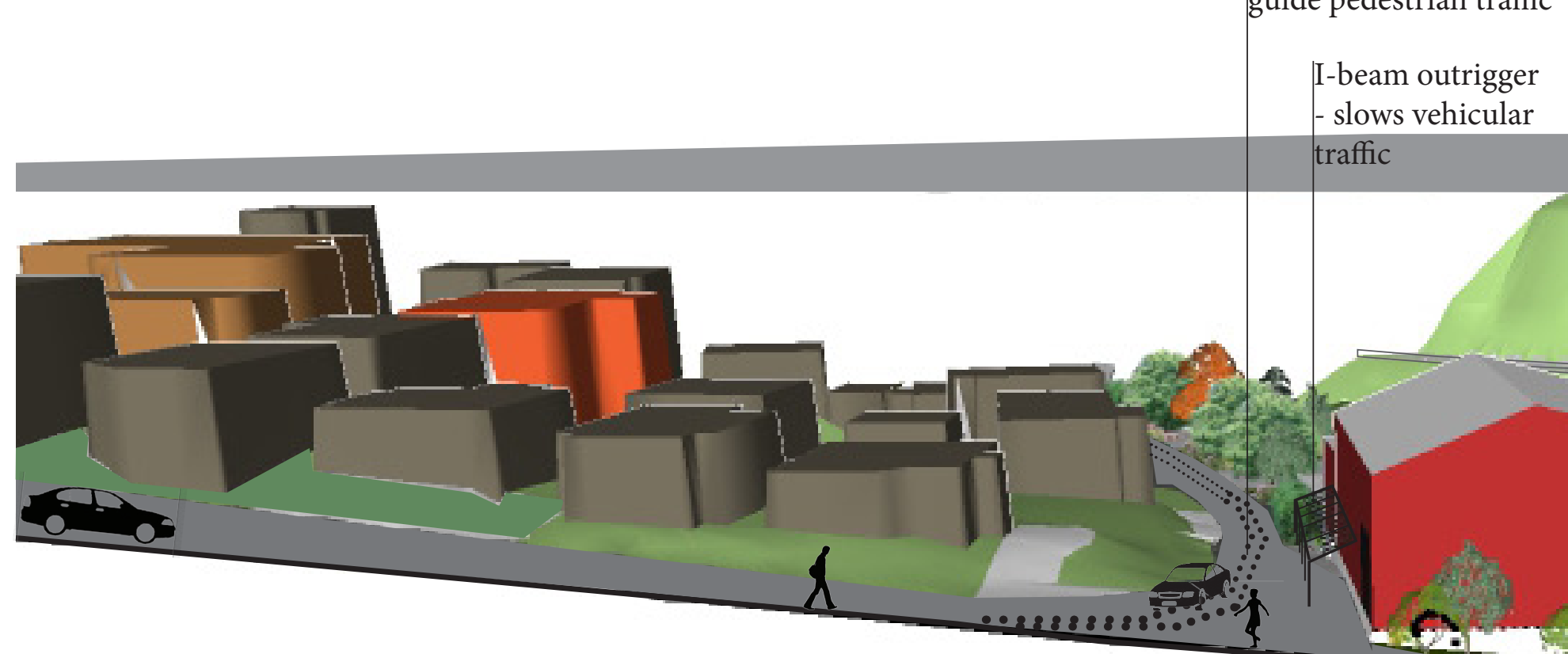

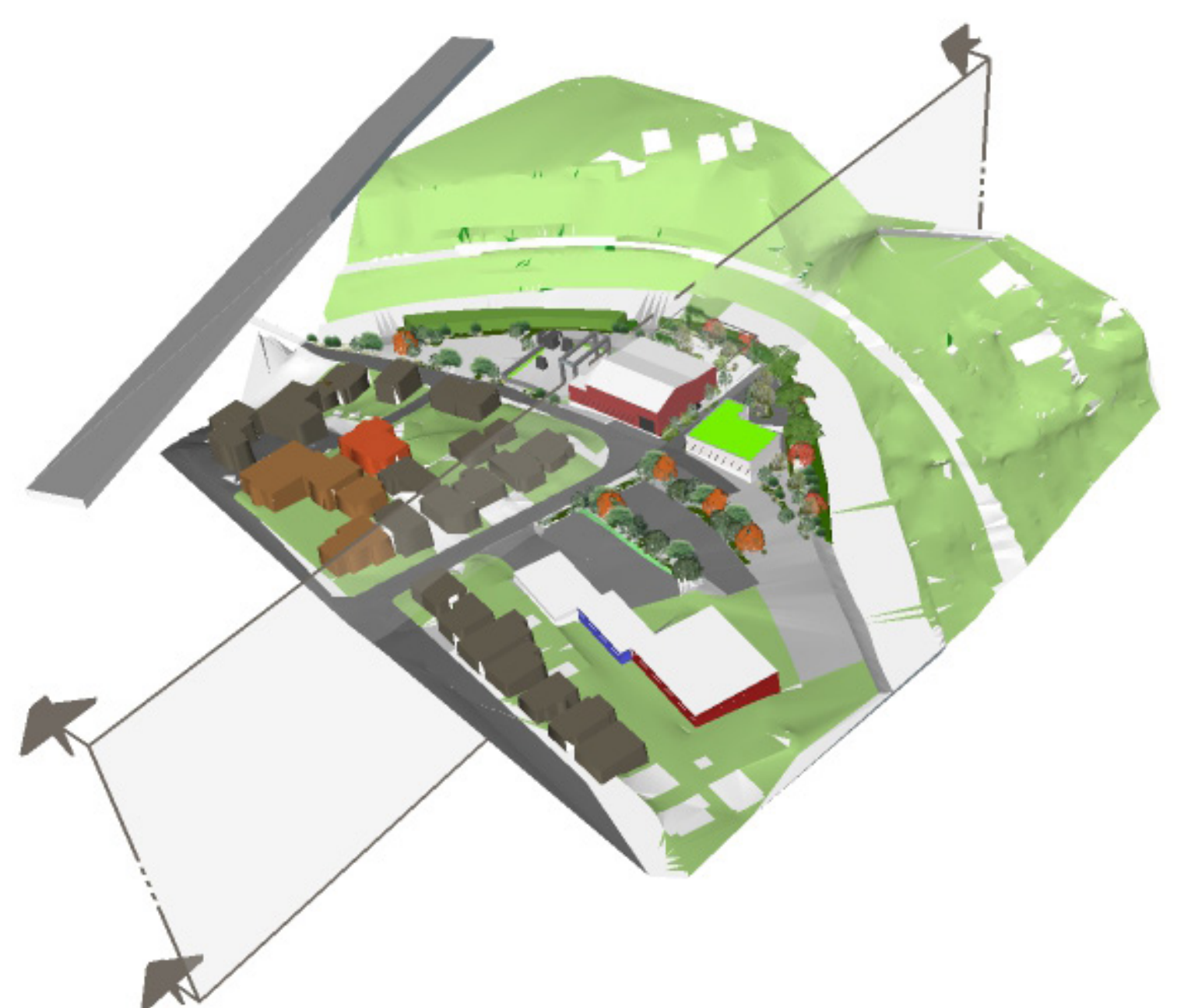

Historic Power Station - iconic

community center

Increased safety perception

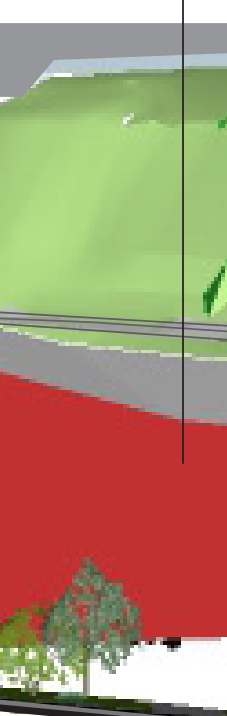

Attractive waterfront open space - attracts trail users into the neighborhood

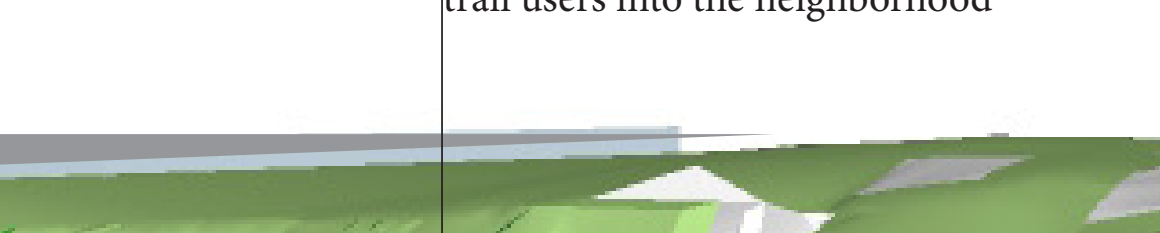




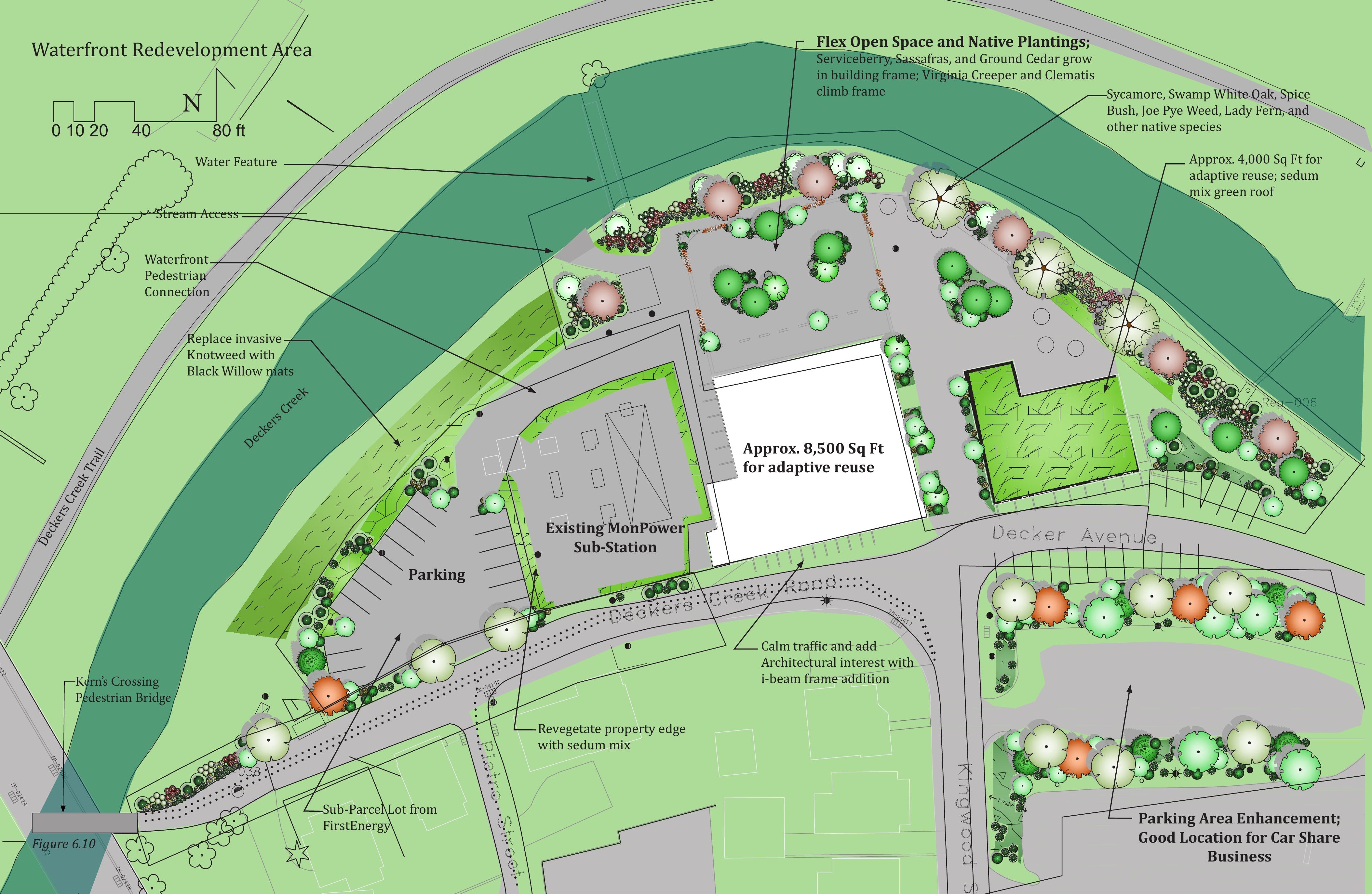




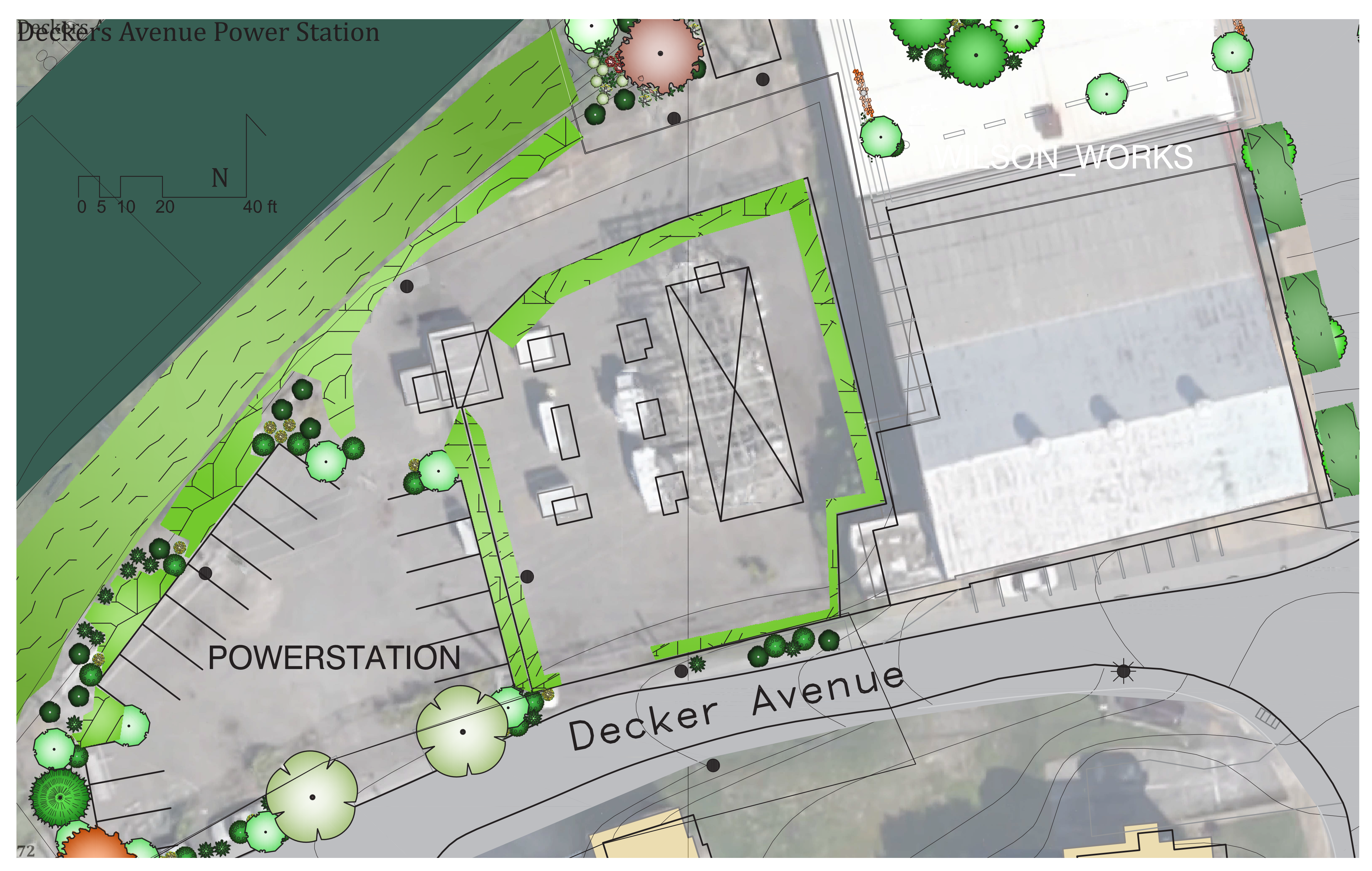




\section{PLANT SCHEDULE WILSON WORKS}

\section{TREES BOTANICAL NAME / COMMON NAME}

Amelanchier alnifolia / Serviceberry

Betula nigra / River Birch

Platanus occidentalis / American Sycamore

Quercus bicolor / Swamp White Oak

Rhus glabra / Smooth Sumac

Sassafras albidum / Sassafras

BOTANICAL NAME / COMMON NAME
SHRUBS

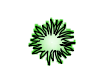

$Q$

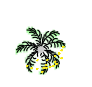

of

$m$

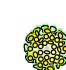

$\odot$

?

解

(a)

$\circ$

\section{Andropogon gerardil / Big Blue Stem}

Ascleplas albicans / Whitestem Milkweed

Athyrium asplenioides / Southern Lady Fern

Botrychium virginianum / Rattlesnake Fern

Clematis virginiana / Virgins Bower

Forsythia ovata / Korean Forsythia

Lindera benzoin / Spicebush

Lobelia X 'Brightness' / Lobelia

Microbiota decussata / Siberian Carpet Cypress

Parthenocissus quinquefolla / Virgina Creeper

ANNUALS/PERENNIALS BOTANICAL NAME / COMMON NAME

*

Eupatorium fistolosum / Joe Pye Weed

GROUND COVERS

BOTANICAL NAME / COMMON NAME

Lycopodium obscurum / Rare clubmoss

Rhus aromatica 'Gro-Low' / Gro-Low Fragrant Sumac

Sedum $\times /$ Sedum var.

$\underline{Q T Y}$

5

10

8

18

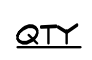

53

44

79

80

6

8

28

62

50

31

$Q T$ $Q T$

\section{PLANT SCHEDULE DECKER AVENUE}

TREES BOTANICAL NAME / COMMON NAME

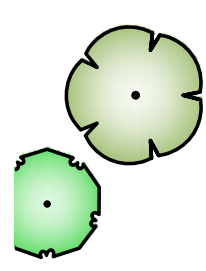

Castanea mollissima / Chinese Chestnet

CONT

Sassafras albidum / Sassafras

BOTANICAL NAME / COMMON NAME

$159 a$

$15 \mathrm{gal}$

SHRUBS

Q

Ascleplas albicans / Whitestem Milkweed

SIZE

5 gal

Athyrium asplenioides / Southern Lady Fern

5 gal

Botrychium virginianum / Rattlesnake Fern

5 gal

Forsythia ovata / Korean Forsythia

5 gal

Lindera benzoin / Splcebush

8

Lobelia x 'Brightness' / Lobelia

$15 \mathrm{gal}$

5 gal

Microbiota decussata / Siberian Carpet Cypress

5 gal

距

Rhododendron x 'Olga Mezitt' / Olga Mezitt PJM Rhe

5 gal

GROUND COVERS BOTANICAL NAME / COMMON NAME

CONT SPACING QTY

flat

$126 \mathrm{sf}$ 
Peckers Avenue Power Station

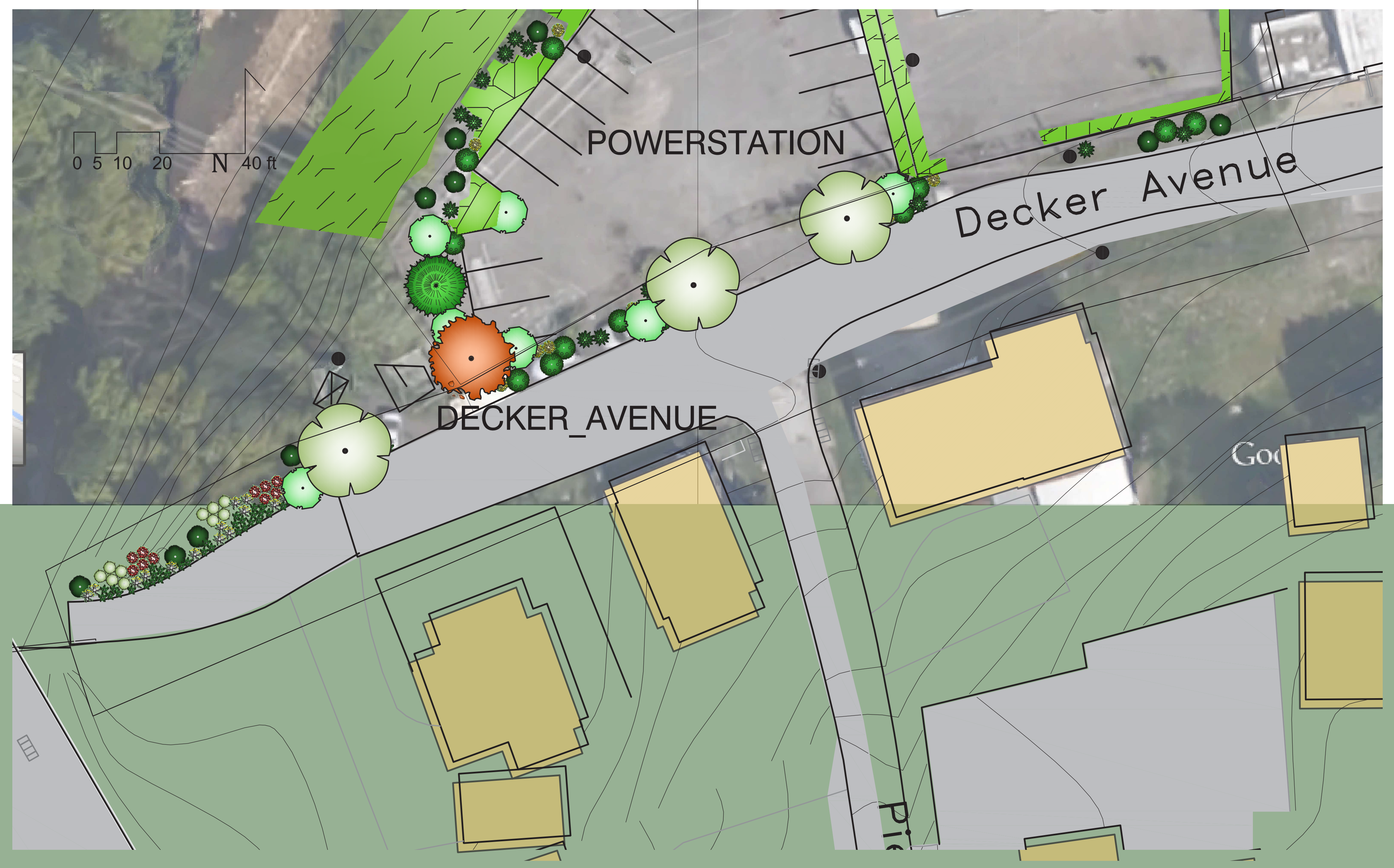




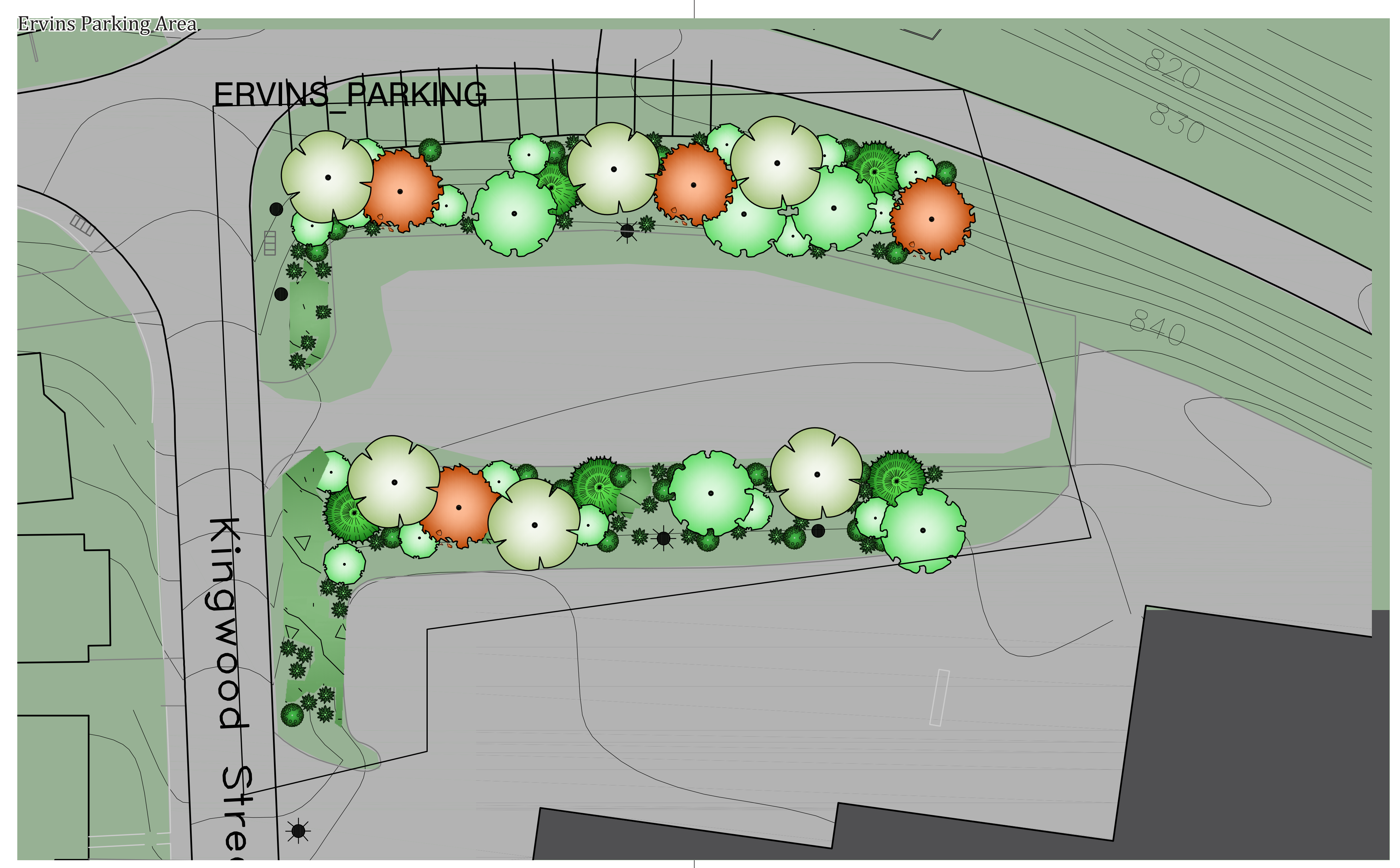




\section{PLANT SCHEDULE DECKER AVENUE}

\begin{tabular}{|c|c|c|c|}
\hline TREES & BOTANICAL NAME / COMMON NAME & CONT & $Q T Y$ \\
\hline & Castanea mollissima / Chinese Chestnet & $15 \mathrm{gal}$ & 3 \\
\hline & Sassafras albidum / Sassafras & $15 \mathrm{gal}$ & 3 \\
\hline SHRUBS & BOTANICAL NAME / COMMON NAME & SIZE & $Q T Y$ \\
\hline Q & Ascleplas albicans / Whitestem Milkweed & $5 \mathrm{gal}$ & 10 \\
\hline 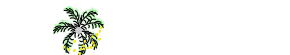 & Athyrium asplenioides / Southern Lady Fern & $5 \mathrm{gal}$ & 19 \\
\hline of & Botrychium Virginianum / Rattlesnake Fern & $5 \mathrm{gal}$ & 40 \\
\hline 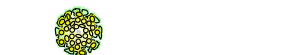 & Forsythia ovata / Korean Forsythia & $5 \mathrm{gal}$ & 6 \\
\hline C & Lindera benzoin / Spicebush & $15 \mathrm{gal}$ & 6 \\
\hline 㪮 & Lobelia x 'Brightness' / Lobelia & $5 \mathrm{gal}$ & 14 \\
\hline 勒 & Microbiota decussata / Siberian Carpet Cypress & $5 \mathrm{gal}$ & 6 \\
\hline 6 & Rhododendron x 'Olga Mezitt' / Olga Mezitt PJM Rhododendron & $5 \mathrm{gal}$ & 9 \\
\hline GROUND COVERS & BOTANICAL NAME / COMMON NAME & CONT SPACING & $\underline{Q T Y}$ \\
\hline & Lycopodium obscurum / Rare Clubmoss & flat & $126 \mathrm{sf}$ \\
\hline
\end{tabular}

\section{PLANT SCHEDULE ERVINS PARKING}

\begin{tabular}{llll} 
BOTANICAL NAME / COMMON NAME & CONT & QTY \\
Carya cordiformis / Bitternut Hickory & $15 \mathrm{gal}$ & 5 \\
Castanea mollissima / Chinese Chestnet & $15 \mathrm{gal}$ & 6 \\
& Pinus alba / White Pine & $15 \mathrm{gal}$ & 5 \\
& Quercus rubra / Red Oak & $15 \mathrm{gal}$ & 4 \\
& BOSsafras albidum / Sassafras & $15 \mathrm{gal}$ & 17 \\
& Microbiota decussata / Siberian Carpet Cypress & SIZE & QTY \\
\hline
\end{tabular}

GROUND COVERS BOTANICAL NAME / COMMON NAME

CONT SPACING QTY

$\ldots$



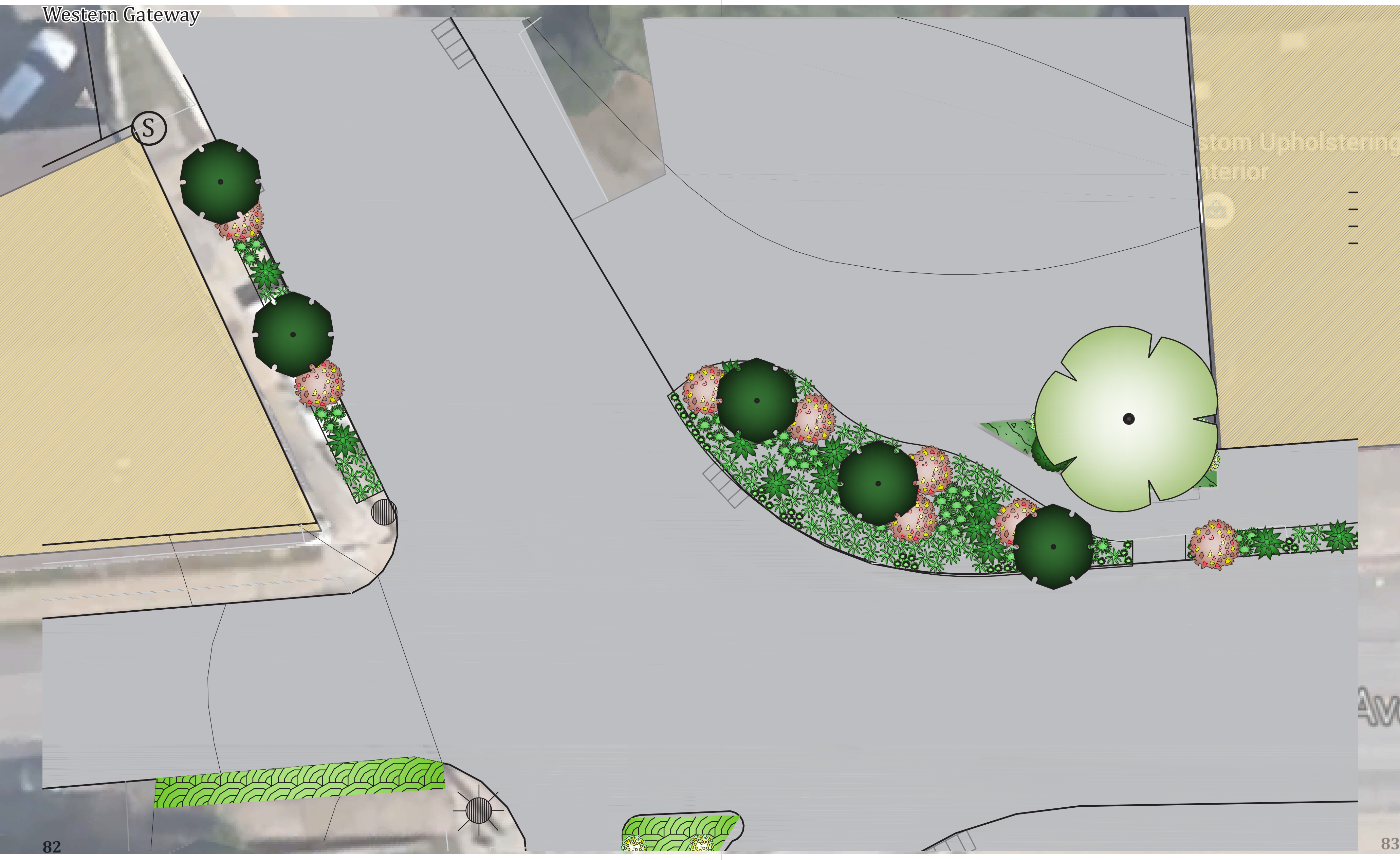


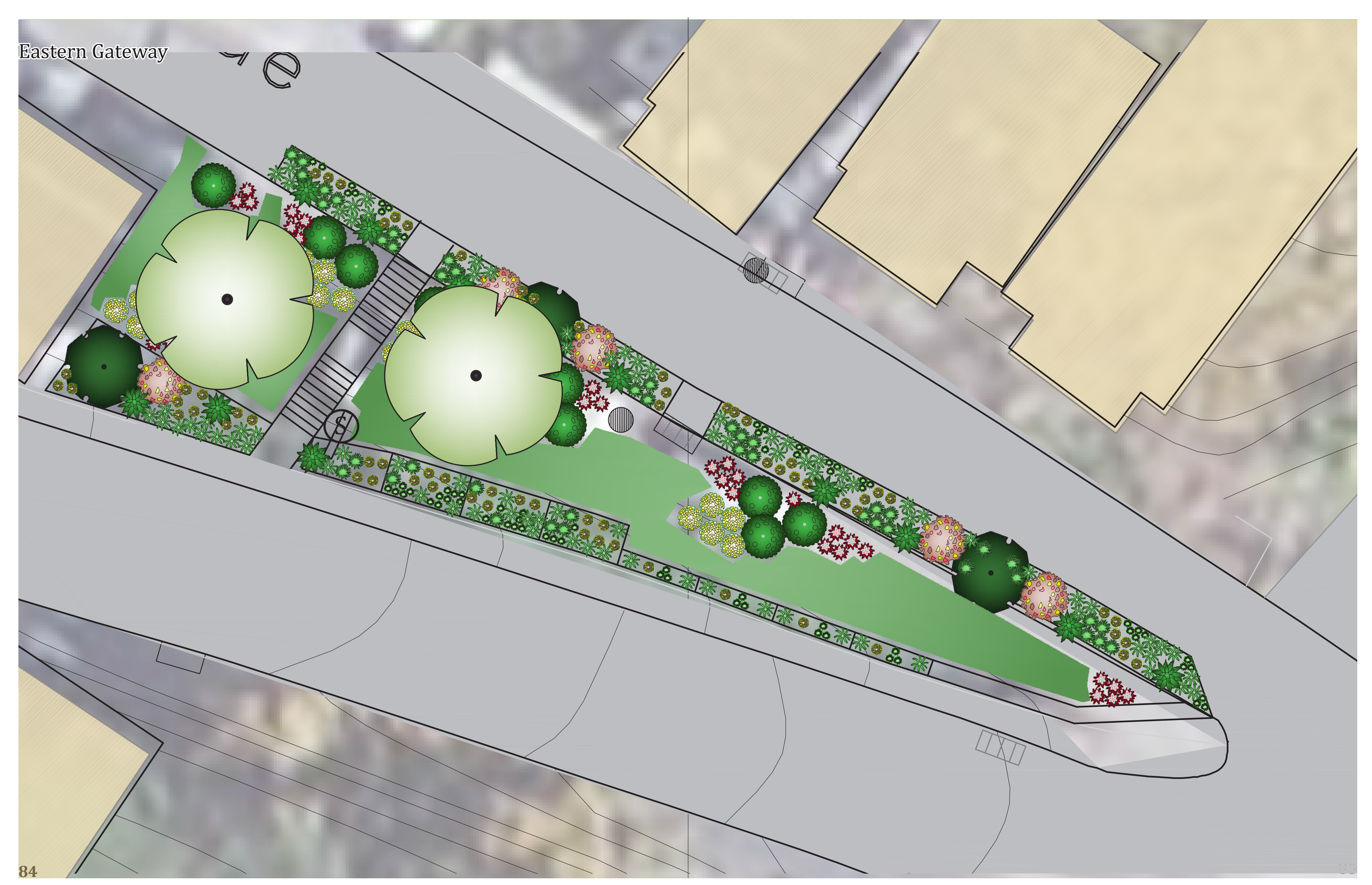




\section{PLANT_SCHEDULE_WESTERNGATEWAY}

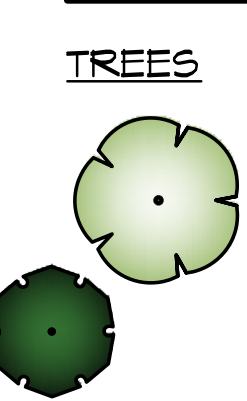

BOTANICAL NAME / COMMON NAME CONT

$\underline{Q T Y}$

$$
\text { Castanea mollissima / }
$$$$
\text { Chinese Chestnet }
$$$$
15 \mathrm{gal}
$$

Ilex glabra / Inkberry Holly 15 gal

SHRUBS BOTANICAL NAME / COMMON NAME SIZE QTY

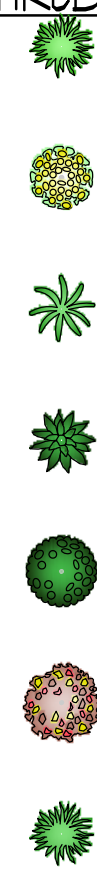

Festuca rubra / Red Fescue 5 gal

45

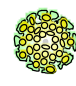

औै

Forsythia ovata

Korean Forsythia

$5 \mathrm{gal}$

Iris versicolor / Blue Flag $5 \mathrm{gal}$

67

Panicum virgatum /

Switch Grass

$5 \mathrm{gal}$

13

Rhododendron x 'Olga Mezitt'

Olga Mezitt PJM Rhododendron $5 \mathrm{gal}$

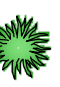

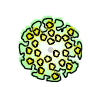

Rosa carolina / Carolina Rose $15 \mathrm{gal} \quad 9$

Sorghastrum nutans / Indian Grass 5 gal $\quad 44$

ANNUALS/PERENNIALS BOTANICAL NAME / COMMON NAME SIZE

$\underline{Q T Y}$

Rudbeckia hirta 'Goldilocks'

Goldilocks Black-Eyed Susan

$5 \mathrm{gal}$

GROUND COVERS BOTANICAL NAME / COMMON NAME CONT SPACING QTY

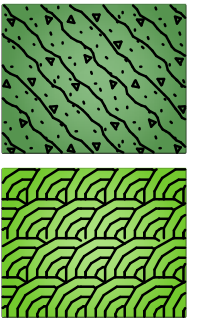

Lycopodium obscurum / Rare Clubmoss flat

41 sf

Sedum $\times$ / Sedum var

flat

183 sf

\section{PLANT_SCHEDULE_EASTERN_GATEWAY}

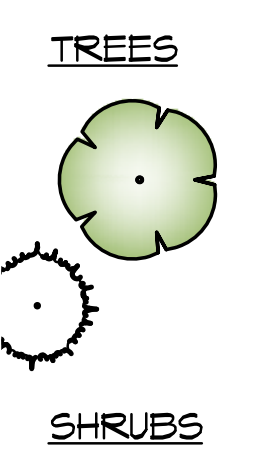

解

$\{$ r.

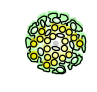

$\sum^{m} w^{3}$

$\xi \dot{3}$

米

0

○

的

GROUND COVERS .
BOTANICAL NAME / COMMON NAME

Castanea mollissima / Chinese Chestnet

llex glabra / Inkberry Holly

BOTANICAL NAME / COMMON NAME

castilleja chromosa / Indian Paintbrush

Festuca rubra / Red Fescue

Forsythia ovata / Korean Forsythia

Iris versicolor / Blue Flag

Oenothera fruticosa / Golden Sundrops

Panicum Virgatum / Switch Grass

Rhododendron x 'Olga Mezitt' /

olga Mezitt PJM Rhododendron

Rosa carolina / Carolina Rose

Sorghastrum nutans / Indian Grass

BOTANICAL NAME / COMMON NAME

Lycopodium obscurum / Rare Clubmoss
CONT

$\underline{Q T Y}$

15 gal

$15 \mathrm{gal}$

SIZE

5 ga

$5 \mathrm{gal}$

$5 \mathrm{gal}$

5 gal

5 gal

$5 \mathrm{gal}$

$5 \mathrm{gal}$

$15 \mathrm{gal}$

5 gal

CONT SPACING

flat
2

3

$\underline{Q T Y}$

32

69

15

85

66

9

5

43

QTY

950 sf 


\section{Next Steps}

Upon the completion of this phase of the neighborhood revitalization design process, continued stakeholder engagement will push neighborhood revitalization forward.

\section{Signage and Hanging Baskets}

A local entity interested in pursuing Brockway Avenue signage and hanging baskets may search for funding so that they may be installed. Members of the GNA have been working on neighborhood signage and may have valuable suggestions for sign design and or location edits.

\section{Planting Plans}

The presentation of native planting plans to the relevant property owners may encourage property owners to install vegetative enhancements to contribute to neighborhood revitalization.

\section{Stormwater Runoff Reduction}

The continued engagement of Morgantown Utility Board is needed to achieve stormwater runoff reduction. To move forward with the proposed plan, a feasibility study and further design details are needed. Also, stormwater management on Baird Street is a high priority for enhancing the redevelopment opportunities of the Wilson Works Property.

\section{Deckers Avenue Power Station}

With the provided design as a long term goal, continued communication and compromise between community stakeholders and First Energy will result in the identification of ways that site

vegetation and access may be restored over time. Native plantings and the proposed sedum mix will mitigate blight and promote permeability and wildlife habitat. The sub parceling of the site will contribute to neighborhood enhancement by providing additional parking and waterfront access.

\section{Wilson Works Redevelopment}

The continued cooperation between the property owner and neighborhood stakeholders will contribute to the transformation of this key waterfront property into a community center that preserves the area's industrial heritage, contributes to the recreational trail environment, and connects the neighborhood to recreational and visual benefits of Deckers Creek.

\section{Waterfront Park}

The proposed waterfront park is located on undeveloped land owned by Joseph Dow. Identifying landowner development and/or plans for continued ownership will help identify site opportunities. A community visioning and site design for this property may contribute to successful park planning

\section{Public Stairway}

As waterfront park and Deckers Avenue traffic enhancements are being pursued, the proposed public stairway may be prioritized by the City, designed, and installed. Increased recreational neighborhood activity will contribute to the safety of this site.

\section{Traffic Enhancements}

The department of highways will need to approve the limiting of truck traffic on Deckers Avenue, the crosswalks on Brockway Avenue, and the painted footpaths on Deckers Avenue, Kingwood Street, and Pietro Street. 


\section{References}

Biohabitats, INC. Design Manual for the use of Bioretention in Stormwater Management. Towson,

City of Durango. Durango Animas River Corridor Management Plan. Durango, Colorado. February 2013. Web: http://www.durangogov.org/DocumentCenter/View/1749. 15 March 2015.

City of Morgantown. City of Morgantown Comprehensive Plan, Adopted June 2013.

Christ, Martin. Watershed Based Plan for the Deckers Creek Watershed: Preston and Monongalia Counties, West Virginia. Friends of Deckers Creek, March 2005. Web: http://www.deckerscreek.org/ images/stories/pdf/Deckers\%20Creek\%20WV\%20Watershed\%20Based\%20Plan.pdf 10 January 2015

Evergreen Brick Works, Inc. Holcim Gallery and Koerner Gardens. Toronto, Ontario. March, 2015. Web: http://www.evergreen.ca/get-involved/evergreen-brick-works/event-space-rental/venues/ holcim-gallery-koerner-gardens/. 15 March 2015.

Farr, Douglas. Sustainable Urbanism: Urban Design with Nature. Hoboken, New Jersey: John Wiley and Sons, 2008.102-111 Print.

Friends of Deckers Creek. Friends of Deckers Creek Brownfields Survey Fall/Winter 2010-2011. Web: http://www.deckerscreek.org/images/stories/Survey_Narrative_131.11_FINAL.pdf 10 January 2015

Gioulis, Michael. United States Department of the Interior National Park Service National Register o Historic Places Registration Form. Monongalia, WV. September, 2004. Web: http://www.wvculture. org/shpo/nr/pdf/monongalia/04001597.pdf. 20 March 2015.

Hester, Randolph. "Subconscious Landscapes of the Heart." Places 2.3 (1985): 10-22. Print.

Holcim Foundation: International Examples of Sustainable Construction. Brick Works Wins 2012 Canadian Green Building Awards. February, 2012. Web: http://www.holcimfoundation.org/ Projects/evergreen-brick-works-heritage-site-revitalization-toronto-can.15 March 2015.

Kaner, Sam et al. Facilitator's Guide to Participatory Decision-Making. San Franscisco, CA: JosseyBass, 2007. Print.

Kretzmann, John P. and John McKnight. Building Communities from the Inside Out. Chicago, Il: ACTA Publications, 1993. Print.

Lynch, Kevin. The City Image and its Elements. The Image of the City (1960). 478-482. Print.

Schrecongost, Alyse and Evan Hansen. Local Economic Benefits of Restoring Deckers Creek: A Preliminary Analysis. Friends of Deckers Creek, August 2005. Print.

Stasick, Lynn. “An Immigrant Story: A Dream Realized”. 2006. Print.
Stasick, Lynn. "The Morgantown Trolley System: In Service to the Community".

Swaffield, Simon. Theory in Landscape Architecture. Philadelphia, PA: University of Pennsylvania Press, 2002. Print.

Tamarack Institute. "Resource at a Glance: Community Reference System”. Tamarack: An Institute for Community Engagement. March 2015. Web: http://tamarackcci.ca/files/resource_at_a glancecommunity_reference system.pdf

United States Census Bureau. “Demographic Trends.” 2011. Web: census.gov. 22 March 2015.

\section{Acknowledgements}

\section{Committee Members}

Peter Butler, Landscape Architecture Professor; Patrick Kirby, Northern WV Brownfields Assistance Center Director; Steven Selin, Parks and Recreation Professor; Charlie Yuill, Landscape Architecture Professor

\section{Contributors}

Carrie Staton - Event Planning and Facilitation, Leah McAllister - Community Background, Martin Christ - Deckers Creek and Environmental Background, Matthew Held - History Background, Doug Gilbert - Deckers Creek and Vegetation Background, Sera Zegre - Focus Group Guidance, Lynn Stasick - Neighborhood History Documents, Kris Knowles - Sustainable Neighborhood Developmen Incite, Chris Fletcher - Stakeholder Connections, David Bott - Project Background, Chris Linger - Utility Data, Ken Hacker - Utility Data, Allen Staggers - Power Station Site Information, Chuck Branch - Waterfront Redevelopment Site Background, Tom Pritts - Waterfront Redevelopment Site Background, Gabe Dewitt - Meeting Photos

\section{Meeting Participants}

Tara Smith, Julie Szymanek, Tom Pritts, Jenny Selin, Bill Kawecki, Gabe Dewitt, Leah McAllister, Rick Landenberger, Nichole Kovach, Steven Selin, Garrett Thompson, Emma Swigart, Troy Woodall, Matthew Held, Chris Haddox, and Lynn Stasick 


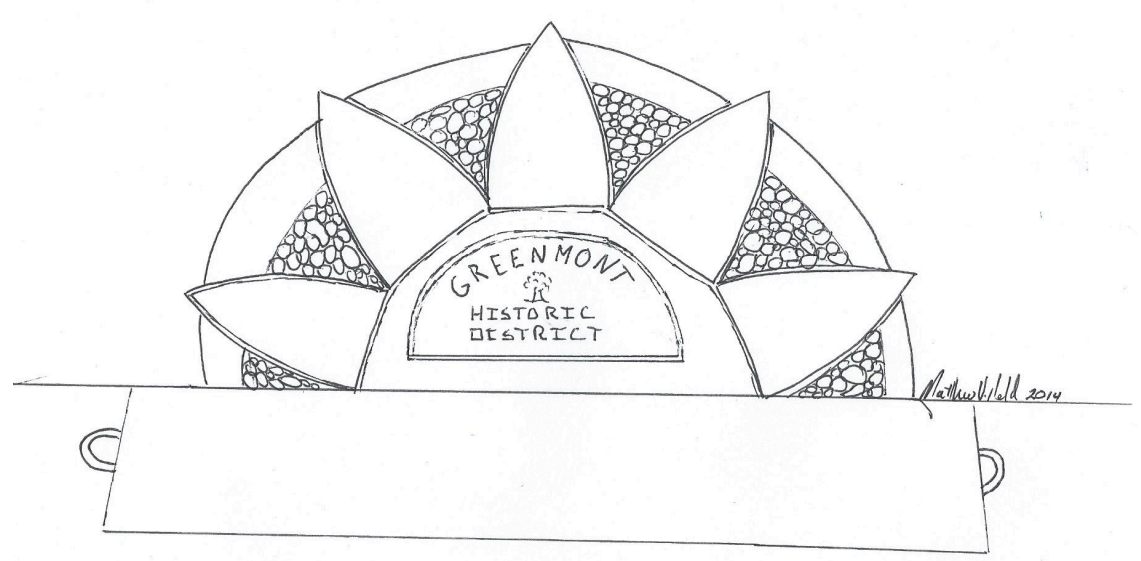

